\title{
Flood-Plain and Channel Aggradation at Selected Bridge Sites in the lowa and Skunk River Basins, lowa
}

BY DAVID A. EASH

\section{U.S. GEOLOGICAL SURVEY}

Water-Resources Investigations Report 95-4290

Prepared in cooperation with the

IOWA HIGHWAY RESEARCH BOARD

and the HIGHWAY DIVISION of the

IOWA DEPARTMENT OF TRANSPORTATION

(lowa DOT Research Project HR-350)

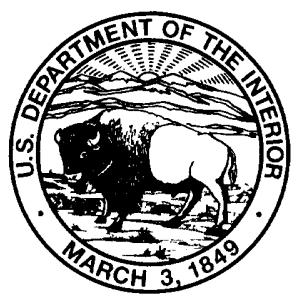




\section{U.S. DEPARTMENT OF THE INTERIOR \\ BRUCE BABBITT, Secretary}

\section{U.S. GEOLOGICAL SURVEY}

Gordon P. Eaton, Director

The use of firm, trade, and brand names in this report is for identification purposes only and does not constitute endorsement by the U.S. Geological Survey.

For additional information write to:

District Chief U.S. Geological Survey

Rm. 269, Federal Building 400 South Clinton Street lowa City, lowa 52244
Copies of this report can be purchased from:

U.S. Geological Survey Information Services Box 25286, Mail Stop 417 Denver Federal Center Denver, CO 80225-0046 


\section{CONTENTS}

Abstract ...

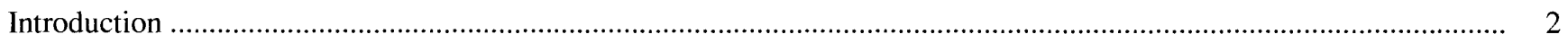

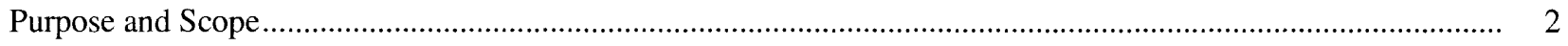

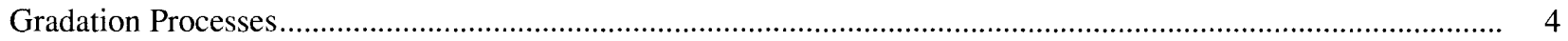

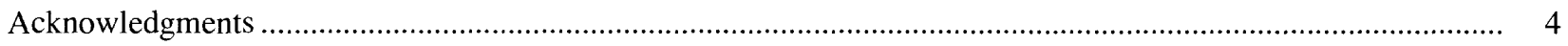

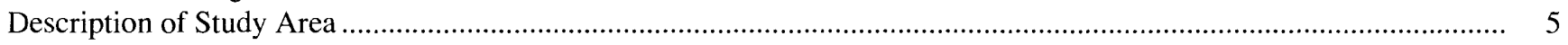

Iowa River Basin Upstream of Coralville Lake .............................................................................................

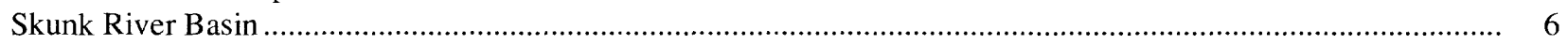

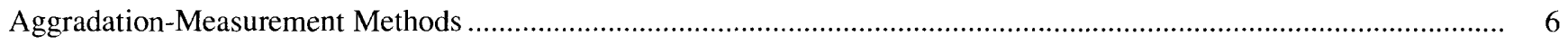

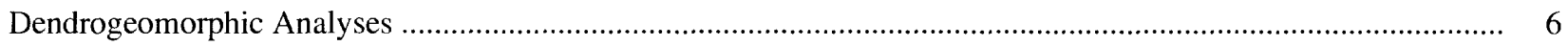

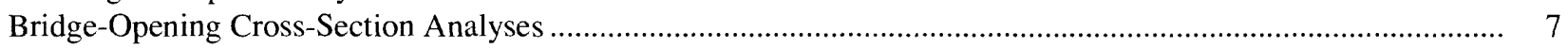

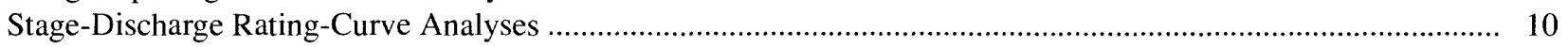

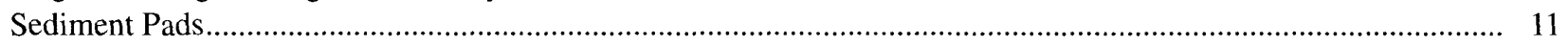

Application and Limitations of Aggradation-Measurement Methods .................................................................... 12

Aggradation Measurements at Selected Bridge Sites in the Iowa and Skunk River Basins ........................................ 15

County Road C38 Bridge Crossing the Iowa River near Rowan ................................................................... 15

Old U.S. Highway 20 Bridge Crossing the Iowa River near Iowa Falls ............................................................. 17

State Highway 175 Bridge Crossing the Iowa River at Eldora .......................................................................... 17

County Road E18 Bridge Crossing the Iowa River near Liscomb ............................................................... 18

State Highway 330 Bridge Crossing the Iowa River near Albion............................................................... 19

State Highway 14 Bridge Crossing the Iowa River at Marshalltown................................................................ 19

U.S. Highway 30 Bridge Crossing the Iowa River near Montour...................................................................... 24

U.S. Highway 63 Bridge Crossing the Iowa River at Tama .............................................................................. 25

State Highway 21 Bridge Crossing the Iowa River near Belle Plaine ................................................................. 25

County Road V66 Bridge Crossing the Iowa River at Marengo ................................................................. 26

U.S. Highway 63 Bridge Crossing the South Skunk River near Oskaloosa ...................................................... 30

State Highway 149 Bridge Crossing the North Skunk River near Sigourney .................................................... 30

Comparison and Discussion of Aggradation Measurements ................................................................................... 33

Possible Factors Contributing to Aggradation of the Iowa River near Marshalltown ....................................................... 35

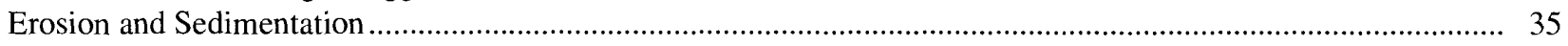

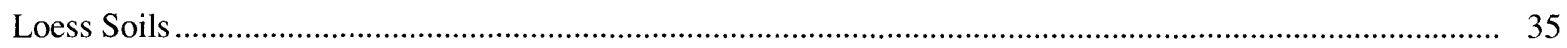

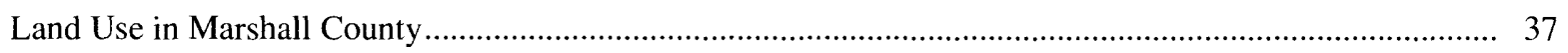

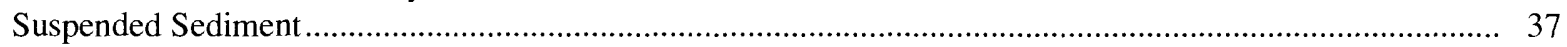

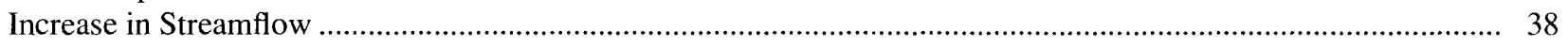

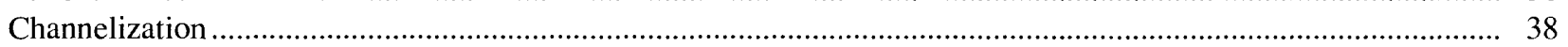

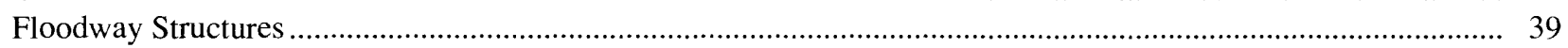

Aggradation Similarities between the Iowa River near Marshalltown and the South Skunk River near Oskaloosa ........... 40

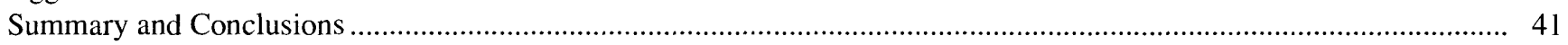

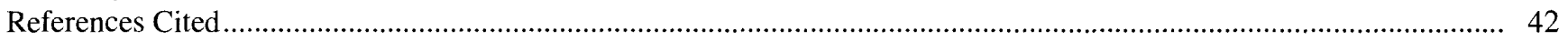

\section{ILLUSTRATIONS}

1. Map showing location of selected bridge sites in the Iowa and Skunk River Basins where aggradation data were collected

2. Sketch showing a tree in an aggrading flood plain and increment borer

3. Graph showing instantaneous gage heights for the Iowa River at Marshalltown for the period March 24, 1993, to November 30, 1994 
4. Photographs showing sediment pads before and after flooding and depth of sediments deposited on pads during the 1993 flood at two bridge sites on the Iowa River.

5. Graphs showing selected bridge-opening cross sections, stage-discharge rating curves, and time series of rating-curve stages for selected discharges for County Road C38 bridge crossing the Iowa River near Rowan.

6.-9. Graphs showing selected bridge-opening cross sections for:

6. Old U.S. Highway 20 bridge crossing the Iowa River near Iowa Falls

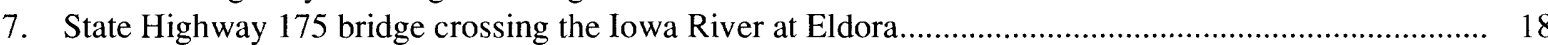

8. County Road E18 bridge crossing the Iowa River near Liscomb .............................................. 19

9 State Highway 330 bridge crossing the Iowa River near Albion ................................................... 20

10. Graphs showing selected bridge-opening cross sections and stage-discharge rating curves for State Highway 14 bridge crossing the Iowa River at Marshalltown

11. Graph showing time series of rating-curve stages for selected discharges, observed stages of selected maximum annual-peak discharges, and construction of floodway structures near the State Highway 14 bridge crossing the Iowa River at Marshalltown

12.-13. Graphs showing selected bridge-opening cross sections for:

12. U.S. Highway 30 bridge crossing the Iowa River near Montour

13. U.S. Highway 63 bridge crossing the Iowa River at Tama

14.-17. Graphs showing selected bridge-opening cross sections, stage-discharge rating curves, and time series of rating-curve stages for selected discharges for:

14. State Highway 21 bridge crossing the Iowa River near Belle Plaine

15. County Road V66 bridge crossing the Iowa River at Marengo

16. U.S. Highway 63 bridge crossing the South Skunk River near Oskaloosa......

17. State Highway 149 bridge crossing the North Skunk River near Sigourney

18. Photograph showing sediment deposits from the 1993 flood along the flood plain of the Iowa River at Marshalltown

19. Graph showing mean annual discharge for the Iowa River at Marshalltown streamflow-gaging station for the period of record through 1994

\section{TABLES}

1. Summary of aggradation-measurement methods used and aggradation rates calculated at selected bridge sites in the Iowa and Skunk River Basins.

2 Summary of aggradation rates calculated for studies conducted in other states......... 


\begin{tabular}{lll}
\hline Multiply & By & To obtain \\
\hline inch (in.) & 25.4 & millimeter \\
foot $(\mathrm{ft})$ & 0.3048 & meter \\
foot per mile $(\mathrm{ft} / \mathrm{mi})$ & 0.1894 & meter per kilometer \\
foot per second $(\mathrm{ft} / \mathrm{s})$ & 0.3048 & meter per second \\
foot per year $(\mathrm{ft} / \mathrm{yr})$ & 0.3048 & meter per year \\
square foot $\left(\mathrm{ft}^{2}\right)$ & 0.09290 & square meter \\
foot per square second $\left(\mathrm{ft} / \mathrm{s}^{2}\right)$ & 0.3048 & meter per square second \\
mile (mi) & 1.609 & kilometer \\
square mile $\left(\mathrm{mi}^{2}\right)$ & 2.590 & square kilometer \\
cubic foot per second $\left(\mathrm{ft}^{3} / \mathrm{s}\right)$ & 0.02832 & cubic meter per second \\
ton, short $(2,000 \mathrm{lb})$ & 0.9072 & megagram \\
ton per square mile per year & 0.003503 & megagram per square \\
& & hectometer per year \\
ton per acre per year & 2.242 & megagram per square \\
& & hectometer per year \\
\hline
\end{tabular}

Sea Level: In this report, "sea level" refers to the National Geodetic Vertical Datum of 1929-a geodetic datum derived from a general adjustment of the first-order level nets of the United States and Canada, formerly called Sea Level Datum of 1929. 


\title{
Flood-Plain and Channel Aggradation at Selected Bridge Sites in the lowa and Skunk River Basins, lowa
}

\author{
By David A. Eash
}

\section{ABSTRACT}

Flood-plain and channel-aggradation rates were estimated at selected bridge sites in central and eastern Iowa using four aggradation-measurement methods. Aggradation rates were quantified at 10 bridge sites on the Iowa River upstream of Coralville Lake and at two bridge sites in the central part of the Skunk River Basin. Measurement periods used to estimate average aggradation rates ranged in length from 1 to 98 years and varied among methods and sites.

A dendrogeomorphic-measurement method used tree-age data and sediment-deposition depths to estimate flood-plain aggradation rates; mean rates calculated at the 12 bridge sites ranged from 0.013 to 0.051 feet per year, and median rates ranged from 0.010 to 0.046 feet per year. A bridge-opening cross-section measurement method compared historic and recent cross sections of bridge openings to estimate aggradation rates at bridge openings; average rates at the 12 bridge sites ranged from -0.977 to 0.500 feet per year. A stage-discharge rating-curve measurement method comparing historic and recent stages for selected discharges used the 5-year flood discharge to estimate floodway- (flood-plain and channel) aggradation rates and used the average discharge to estimate channel-aggradation rates. Average rates calculated for selected measurement periods at six of the bridge sites ranged from -0.028 to 0.298 feet per year for the 5 -year flood discharge, and from -0.031 to 0.108 feet per year for the average discharge. Nine sediment pads installed on the Iowa River flood plain at three bridge sites in the vicinity of Marshalltown, prior to overbank flooding in 1993, were used to measure sediment-deposition depths and to estimate flood-plain aggradation rates resulting from the 1993 flood and for the period 1993-94. Average rates estimated from the sediment-pad measurements ranged from 0.037 to 1.100 feet per year for 1993, and from 0.038 to 0.579 feet per year for the period 1993-94. Sediments deposited on the pads as a result of the 1993 flood ranged in depth from 0.004 to 2.95 feet.

A direct comparison cannot be made between aggradation rates calculated using each of the four measurement methods because of differences in time periods and aggradational processes that were measured by each method. Each of the four aggradation-measurement methods is useful for obtaining specific types of aggradation information and each method is considered applicable for specific types of regional investigations. The rating-curve method might provide the most useful information concerning floodway and channel aggradation, but rating-curve information only is available at streamflow-gaging stations with a chronology of stage-discharge rating curves. The bridge-opening cross-section method does not provide direct measurements of floodplain or channel aggradation, but this method does provide useful information concerning possible changes in the flow capacity of bridge openings.

The highest aggradation rates calculated for the Iowa River Basin using the dendrogeomorphic and rating-curve measurement methods were for the State Highway 14 crossing at Marshalltown, where these highest rates were 0.045 and 0.124 feet per year, respectively. The highest 
aggradation rates calculated for the Skunk River Basin were for the U.S. Highway 63 crossing the South Skunk River near Oskaloosa, where these highest rates were 0.051 and 0.298 feet per year, respectively. The similar aggradation rates calculated for both the Marshalltown and Oskaloosa bridge sites using each measurement method, the dendrogeomorphic method and the rating-curve method for the 5-year flood discharge, indicate that similar flood-plain and floodway aggradation processes might be occurring at the two sites.

Several interrelated factors might be contributing to the relatively high rate of aggradation of the Iowa River at Marshalltown. Erosion in the Marshall County area might contribute high sediment yields to the Iowa River, and channelization of the Iowa River upstream of Marshalltown might contribute to higher sediment loads in the Iowa River in the Marshalltown area. At Marshalltown, where the Iowa River changes abruptly from a straightened channel to a meandering channel, flow velocities decrease as the channel gradient decreases, reducing the sediment-transport capacity of the river. Information on recent aggradation rates indicates that the Iowa River at Marshalltown might be aggrading at a rate greater than that calculated for longer measurement periods. A trend of increasing streamflow for the Iowa River at Marshalltown combined with an aggrading channel might be causing more frequent overbank flows and increased flood-plain aggradation.

\section{INTRODUCTION}

Knowledge of the rates of aggradation for streams in Iowa is beneficial to planners and engineers in the design of bridges, culverts, causeways, and other structures located across or along streams. In the past, these structures have been designed using historic flood data or derived flood information (Lara, 1987; Eash, 1993). Design-flood profile elevations, based on the flood information, were computed for the existing flow capacity of bridge openings to determine the appropriate bridge and causeway elevations. In the design of these structures, flood-plain and channel aggradation was not considered, and consequently the present flow capacity of some bridge openings and culverts might be less than the original design capacity. The reduction in the flow capacity of a bridge opening or culvert would increase the backwater and might compromise the integrity of the structure.

Effects of aggradation could also be important in the design of road-grade elevations for causeways constructed across flood plains.

Figure 1 shows the Iowa River Basin upstream of Coralville Lake and the Skunk River Basin, and the location of selected bridge sites in the Iowa and Skunk River Basins where aggradation data were collected in this study. An analysis conducted by Heinitz (1973, p. 14-15) of stage-discharge rating curves for the Iowa River at Marshalltown (U.S. Geological Survey streamflow-gaging station number 05451500 ; fig. 1 , site 6), indicated a continual upward re-definition of the rating for the period of record. Heinitz (1973) explained the shifts in the rating to be the result of the construction of dikes, bridges, roads, residential and industrial developments, and other factors.

The highest stages since at least 1915 were recorded on the Iowa River at Marshalltown during 1990, 1991, and 1993, yet recurrence intervals for these three flood discharges were estimated to be 9,6 , and 16 years, respectively. Following the occurrence of the 1990 and 1991 floods, the Iowa Department of Transportation (IDOT) indicated a concern that aggradation on the Iowa River might be affecting the flow capacity of bridge openings in the vicinity of Marshalltown (Brad Barrett, Preliminary Bridge Design, Iowa Department of Transportation, oral commun., January 1992). In response to this concern, the U.S. Geological Survey (USGS) began a 3-year cooperative project with the Iowa Highway Research Board and the Highway Division of the Iowa Department of Transportation in the fall of 1992 to develop an improved understanding of flood-plain and channel aggradation in the Iowa and Skunk River Basins.

\section{Purpose and Scope}

The purpose of this report is to: (1) document the occurrence of flood-plain and channel aggradation and quantify rates of aggradation at 10 selected bridge sites in the Iowa River Basin and at two selected bridge sites in the Skunk River Basin (fig. 1); (2) assess the applicability of aggradation-measurement methods used in this study for conducting similar investigations on a regional or statewide basis; and 


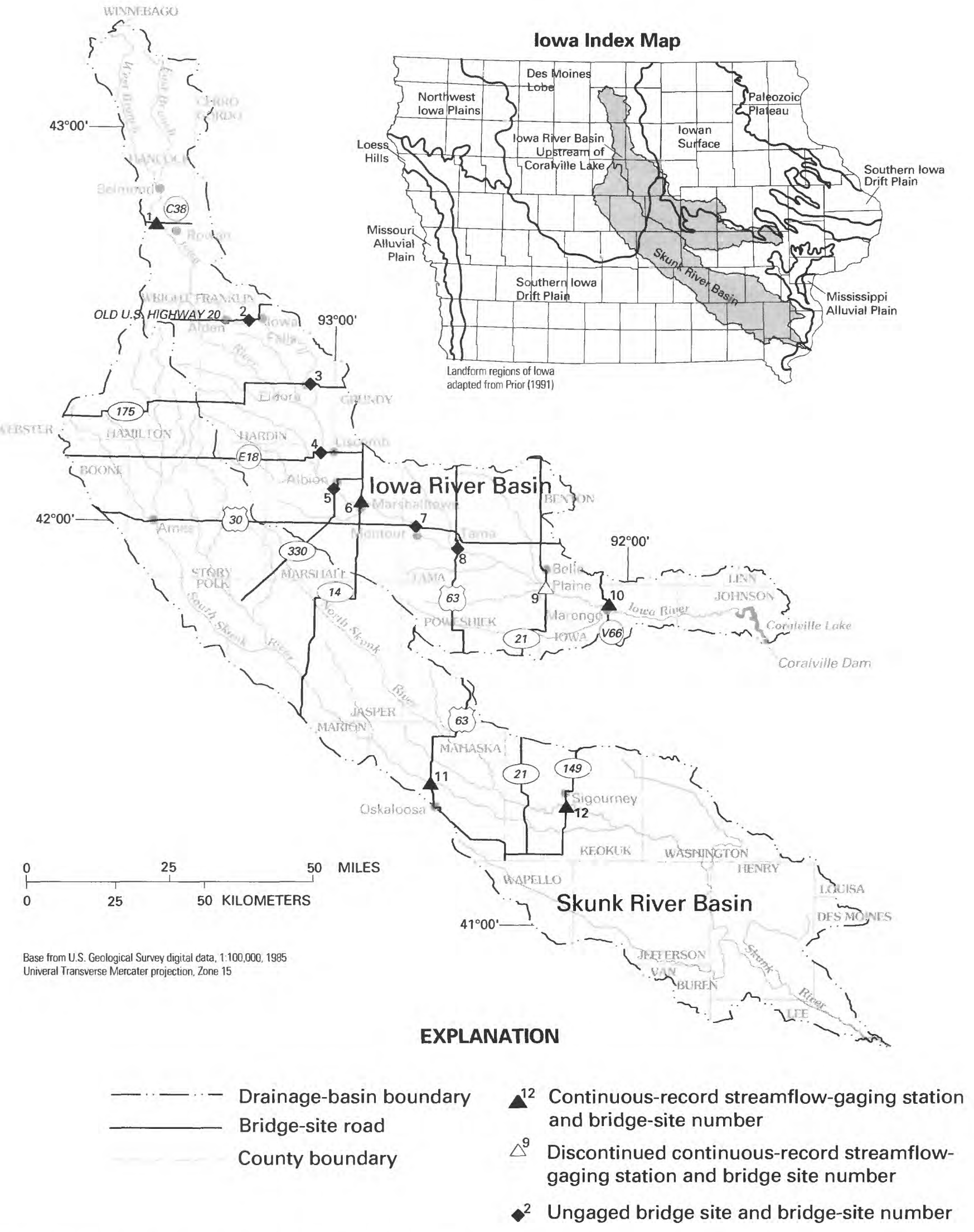

Figure 1. Location of selected bridge sites in the lowa and Skunk River Basins where aggradation data were collected. 
(3) identify factors contributing to aggradation for a selected reach of the Iowa River near Marshalltown.

The report describes flood-plain and channel aggradation at selected bridge sites on the main stem of the Iowa River upstream of Coralville Lake. The State Highway 330 and State Highway 14 bridges in Marshall County, and the U.S. Highway 30 bridge in Tama County, were specifically selected by the IDOT to address concerns that aggradation on the Iowa River might be particularly severe in the vicinity of Marshalltown (fig. 1, sites 5, 6, and 7, respectively). Seven other bridges on the Iowa River both upstream and downstream of the Marshalltown area (fig. 1, sites 1-4 and 8-10) also were selected in conjunction with the IDOT. For comparative purposes, two bridges in the central part of the Skunk River Basin (fig. 1, sites 1112) also were selected to determine whether similar aggradation processes might be occurring in the Skunk River Basin. The report is based on field data collected during the spring and fall of 1993 and 1994.

\section{Gradation Processes}

The physical characteristics of stream channels constantly adjust to changes in land use, water use, and climate to maintain the most efficient conditions for transporting water and sediment load (Vanoni, 1975). Stream grading is the process used to adjust for the changes. According to Mackin (1948, p. 471):

"A graded river is one in which, over a period of years, slope and channel characteristics are delicately adjusted to provide, with available discharge, just the velocity required for the transportation of the load supplied from the drainage basin. The graded stream is a system in equilibrium; its diagnostic characteristic is that any change in any of the controlling factors will cause a displacement of the equilibrium in a direction that will tend to absorb the effect of the change."

Any change, whether natural or human induced, in the hydrologic, climatic, or geologic characteristics of a drainage basin can cause a channel (or a reach of a channel) to lose equilibrium (U.S. Army Corps of Engineers, 1990, p. 5-6). For example, a sedimenttransport imbalance will occur if there is a change in mean flow velocity within a channel reach, because sediment discharge is dependent on flow velocity (Nakato, 1981, p. 1). An imbalance also will occur if the sediment input to the system is changed without accompanying changes in the sediment-transport capacity. In most alluvial rivers, such changes occur continually; therefore, to transport sediment with maximum efficiency, the channel is always compensating for these changes by eroding its bed (degradation), depositing part of its sediment load (aggradation), or changing its course to increase or decrease its length (meandering). By means of such adjustments, a stream tends toward a certain hydraulic geometry and slope that has been described by some researchers as "dynamic equilibrium" (Winkley, 1981). The energy input must equal the energy expended for an alluvial channel to be in equilibrium (U.S. Army Corps of Engineers, 1990, p. 6). Lane (1955) termed this general balance "stream power" and he proposed the following proportionality:

$$
\mathrm{QS} \propto \mathrm{Q}_{\mathrm{S}} \mathrm{D}_{50}
$$

where $\mathrm{Q}$ is water discharge;

$S$ is channel gradient;

$\mathrm{Q}_{\mathrm{S}}$ is bed-load discharge; and

$D_{50}$ is median grain size of bed-load material.

Land-use changes in a drainage basin cause variability in sediment yield (quantity of sediment contributed from the drainage area) and disrupt the stability of a graded river (Bloom, 1978). The introduction of large-scale agricultural tillage throughout a drainage basin can substantially increase the sediment yield. This increase in sediment yield is frequently in excess of the sediment-transport capacity of the river and the excess sediment is deposited on the flood plain and streambed. This process is referred to as aggradation and the typical deposition occurrences are floodplain deposits, point-bar deposition, and streambed aggradation (Odgaard, 1984, p. 1). Over a period of years, aggradation can decrease the grade of a reach of river by increasing the elevation of the flood plain and streambed along the downstream end of the reach. Increasing the elevation of the flood plain and streambed decreases the cross-sectional area of a floodway and reduces the conveyance or flow capacity of a river, and consequently raises the stage of the river for a given discharge.

\section{Acknowledgments}

Various Federal, State, and local agencies cooperated in the collection of streamflow records used in this report, the acknowledgment of which is contained 
in the annual water-data reports of the USGS (U.S. Geological Survey, 1904-1995). The author expresses his gratitude to the following: Brad Barrett and Donald Schumann, IDOT, for supplying bridge-situation plans and information on the State Highway 14 bridge; Ed Kasper, Marshall County Engineer, for supplying the Iowa River channelization plan and bridge-situation plans; Dana Holland, U.S. Department of Agriculture, Natural Resources Conservation Service, Marshall County Field Office, for supplying information on land use and watersheds in Marshall County; Garry Brandenburg, Director, Marshall County Conservation Board, for supplying information on channelization of the Iowa River; and Leon Lamer, General Manager, Marshalltown Water Works, for supplying an aerial photo of the Iowa River at Marshalltown.

\section{DESCRIPTION OF STUDY AREA}

The Iowa and Skunk Rivers are both southeasterly flowing tributaries to the Mississippi River and their combined watersheds drain a major part of central and eastern lowa (fig. 1). The Iowa River Basin upstream of Coralville Lake and the Skunk River Basin are similar in many respects: both river basins have a long and narrow shape, landuse in both basins is primarily agricultural, the physiographic characteristics of both river basins are similar, and the upper portion of both river basins originates on the youthful topography of the Des Moines Lobe landform region and flows onto the more mature topography of the Southern Iowa Drift Plain landform region (fig. 1).

The Des Moines Lobe landform region is characteristic of a young, postglacial landscape that is unique with respect to the rest of the State (Prior, 1991, p. 30-47). The Des Moines Lobe generally comprises low-relief terrain, accentuated by natural lakes, potholes, and marshes, where surface-water drainage typically is poorly defined and sluggish. Soils of the Des Moines Lobe generally consist of friable, calcareous loam glacial till with thick deposits of compact, uniform pebbly loam (Oschwald and others, 1965, p. 28; Prior, 1991, p. 39). The Southern Iowa Drift Plain is characteristic of an older, postglacial landscape that has eroded to form a steeply to gently rolling topography and a well-established drainage system (Prior, 1991, p. 58-61).

\section{lowa River Basin Upstream of Coralville Lake}

The Iowa River originates in north-central Iowa at the confluence of the East and West Branches of the Iowa River near Belmond (fig. 1). Streamflow in the Iowa River downstream of Coralville Lake has been controlled since 1958 by the operation of the Coralville Dam. The Iowa River Basin upstream of the Coralville Dam covers $3,115 \mathrm{mi}^{2}$ and includes parts of 17 counties. During the early 1920's, the channel of the Iowa River was straightened from the Hardin-Marshall County line downstream to Marshalltown.

The Iowa River is slow moving and shallow from Belmond to the Franklin-Hardin County line (Iowa Natural Resources Council, 1955a, p. 5). Between Alden and Eldora, the river flows through limestone and sandstone rock gorges which are deep and narrow for most of this 35-mi reach. Between Iowa Falls and Eldora there is very little tributary drainage to the lowa River. Downstream from Eldora, the river valley widens and is subject to considerable inundation during high floods (Heinitz, 1973, p. 5). The width of the Iowa River valley increases from about $0.3 \mathrm{mi}$ upstream of Eldora to about $1.2 \mathrm{mi}$ downstream of Eldora (Salisbury and others, 1968, p. 75). Near the Marshall-Tama County line, the river valley narrows to gorge-like conditions again, for a short distance, as the river flows through another bedrock outcrop area. The river valley remains generally broad through Tama, Iowa, and Johnson Counties downstream to Coralville Lake.

In the vicinity of Alden and downstream, the topography of the Iowa River Basin becomes the hill and valley landscape typically found throughout most of the State (Heinitz, 1973, p. 5). The Iowa River crosses from the Des Moines Lobe landform region to the Southern Iowa Drift Plain landform region near Eldora (fig. 1) and continues across this landform region for most of the remaining distance downstream to Coralville Lake. Major drainageways in the Southern Iowa Drift Plain are deeply dissected and much of the original surface is preserved on broad, flat uplands (Iowa Natural Resources Council, 1955a, p. 3). These table-like uplands are drained by broad, shallow valleys which deepen into steep-walled, gorge-like ravines near the major streams. Soils of the Southern Iowa Drift Plain in the Iowa River Basin generally consist of moderately permeable silty clay loam that formed from thick loess-covered glacial till under for- 
est and prairie vegetation (Oschwald and others, 1965, p. 35 and 67).

Downstream from Eldora, tributaries draining to the Iowa River from the east and north originate on the Iowan Surface landform region; and the Iowa River crosses the Iowan Surface, for a short distance, where this landform region extends southerly along the Marshall-Tama County line (fig. 1). The Iowan Surface is an erosional landscape that usually appears slightly inclined to gently rolling with long slopes and low relief (Prior, 1991, p. 68-69). Drainage networks are well established, though stream gradients usually are low. The glacial drift of the Iowan Surface is not as thick as that of the Des Moines Lobe and loess deposits are not as thick as those of the Southern Iowa Drift Plain (Iowa Natural Resources Council, 1955a, p. 3).

Mean annual precipitation in the Iowa River Basin upstream of Coralville Lake for the period 1961-90 ranged from approximately $32.31 \mathrm{in}$. in the vicinity of the headwaters to $35.11 \mathrm{in}$. near Coralville Lake (Owenby and others, 1992, p. 75). Mean annual runoff in the upper portion of the basin for the period 1941-94 was 7.36 in., as determined at the Iowa River near Rowan (streamflow-gaging station number 05449500; fig. 1, site 1). Mean annual runoff in the Iowa River Basin upstream of Coralville Lake for the period 1957-94 was 9.56 in., as determined at the Iowa River at Marengo (streamflow-gaging station number 05453100; fig. 1, site 10) (May and others, 1995, p. 73 and 83).

\section{Skunk River Basin}

The Skunk River Basin originates near the center of the State and parallels the Iowa River Basin to the south (fig. 1). The Skunk River Basin covers 4,355 $\mathrm{mi}^{2}$ and includes parts of 20 counties (Heinitz and Wiitala, 1978, p. 2). The Skunk River Basin includes parts of the Des Moines Lobe and Southern Iowa Drift Plain landform regions. The transition boundary between these two landform regions in the Skunk River Basin is in northwestern Jasper and southwestern Marshall Counties (fig. 1). The Southern Iowa Drift Plain is not completely dissected in the Skunk River Basin and is preserved along a considerable portion of the watershed in flat, tabular divides which are well drained by head-working streams (Iowa Natural Resources Council, 1957, p. 3 and 7). The channel of the South Skunk River has been straightened from near Ames downstream through Mahaska County.
Through this reach, the flood plain of the South Skunk River is as much as 2-mi wide. The channel of the North Skunk River has been straightened through most of Jasper County. The flood plain of the North Skunk River varies from narrow to about 1-mi wide.

Mean annual precipitation in the Skunk River Basin for the period 1961-90 ranged from approximately 33.43 in. in the vicinity of the headwaters to 36.40 in. in the lower part of the basin (Owenby and others, 1992, p. 75-76). Mean annual runoff in the South Skunk River Basin for the period 1946-94 was 8.60 in., as determined at the South Skunk River near Oskaloosa (streamflow-gaging station number 05471500; fig. 1, site 11). Mean annual runoff in the North Skunk River Basin for the period 1946-94 was 8.99 in., as determined at the North Skunk River near Sigourney (streamflow-gaging station number 05472500; fig. 1, site 12) (May and others, 1995, p. 119-120).

\section{AGGRADATION-MEASUREMENT METHODS}

Table 1 lists four aggradation-measurement methods used in this study to estimate aggradation rates-dendrogeomorphic, bridge-opening cross-section, and stage-discharge rating-curve analyses, and sediment-pad measurements. Measurement periods used to estimate aggradation rates varied among methods and sites (table 1). The dendrogeomorphic analyses and sediment-pad measurements provided estimates of flood-plain aggradation rates. The stagedischarge rating-curve analyses provided estimates of floodway (flood plain and channel) and channel aggradation rates. The bridge-opening cross-section analyses provided estimates of aggradation rates at bridge openings.

\section{Dendrogeomorphic Analyses}

Dendrogeomorphic analyses were used to quantify mean and median flood-plain aggradation rates at each of 12 selected bridge sites (table 1). The dendrogeomorphic analyses used measurements of annualgrowth rings of trees and burial depths of tree roots to calculate aggradation rates. Figure 2 illustrates a tree in an aggrading flood plain and an increment borer used to extract an increment core for measurement of annual-growth rings. 


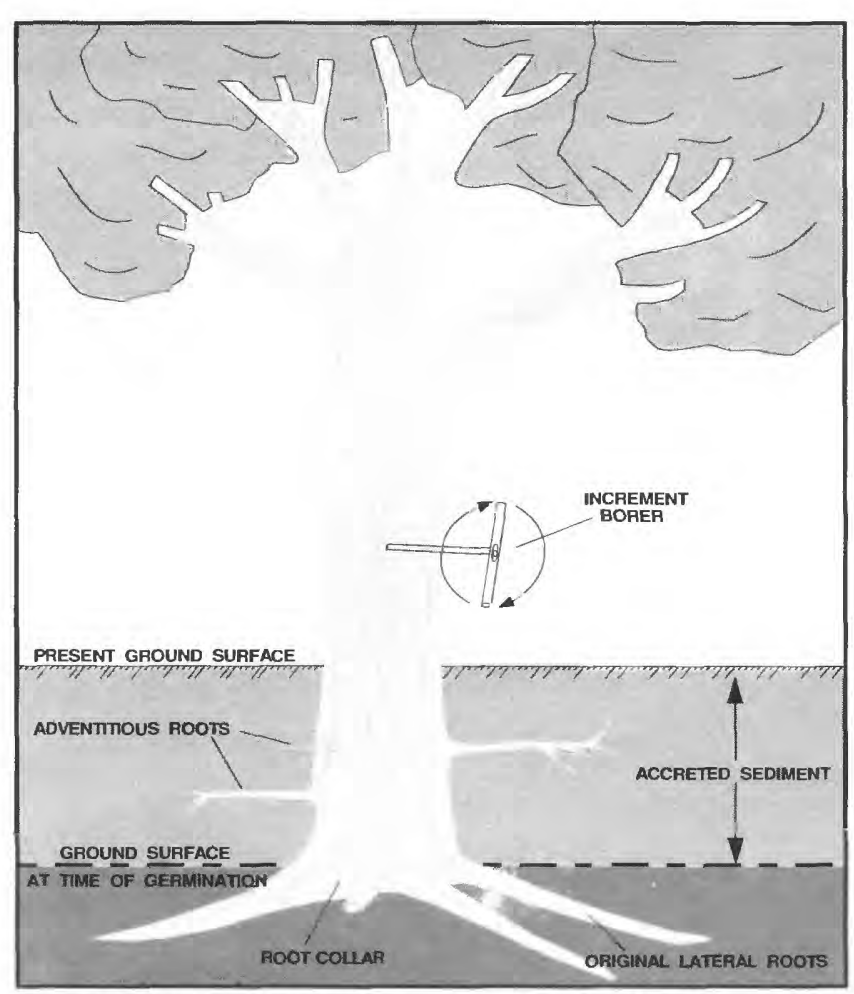

Figure 2. A tree in an aggrading flood plain and an increment borer.

Trees typically produce an extensive root zone just below the ground surface upon germination (Hupp and Simon, 1991, p. 116). This basal flare, or root collar, is a distinctive marker of the original ground surface at the time of germination. Episodic sediment deposition might completely bury the root collar at the base of a tree. A tree subjected to sediment deposition can typically be identified by the absence of a root collar at the base of the trunk. Exhuming a buried tree trunk to the depth of the root collar allows measurement of the net depth of sediment deposited since germination. The age of the tree is determined by extracting an increment core from the base of the tree (about 3 to $4 \mathrm{ft}$ above ground surface). Ring counts made from the biological center (first year of growth) to the outside ring of the increment core provide the age of the tree at the time of the coring (Hupp and Bazemore, 1991, p. 4-42). Dividing the depth of the root burial by the age of the tree yields an estimate of the average rate of flood-plain aggradation during the life of the tree.

Dendrogeomorphic data were collected from 256 trees of 11 species at the 12 bridge sites during October and November 1993. In general, dendrogeomorphic data were collected for five or more trees on approximately the same topographic level of the flood plain and located at least one bridge-length away from each of the four corners of the bridge. The trees measured were selected randomly from those meeting the location requirements. Ring counts were initially performed in the field using a hand lens and subsequently verified in the office using a microscope. The procedures for collecting and preparing increment cores for ring counts are documented by Phipps (1985). Trees sampled for the dendrogeomorphic analyses ranged in age from 9 to 98 years.

\section{Bridge-Opening Cross-Section Analyses}

Historic bridge-opening cross sections were compared to recent bridge-opening cross sections to quantify average aggradation rates at bridge openings at each of the 12 selected bridge sites (table 1). Recent bridge-opening cross sections for each bridge were obtained from transit surveys performed by USGS personnel during the spring of 1994, with the exception of the State Highway 149 bridge crossing the North Skunk River near Sigourney (site 12), where the recent bridge-opening cross section was obtained from a discharge measurement made in 1993.

Historic bridge-opening cross-section and bridge-geometry data used in the analyses were obtained from IDOT bridge-situation plans that list the elevations and stationing of bridge-opening excavations for the bridges. Bridge-situation plans are design plans prepared prior to construction of the bridges. The bridge-opening cross-section analyses performed in this study assumed that bridge openings were excavated to the dimensions shown in the bridge-situation plans.

At four of the six bridge sites where USGS streamflow-gaging stations were located, additional historic and recent bridge-opening cross sections were obtained from discharge-measurement notes. Historic and recent cross sections of bridge openings for the downstream side of each bridge were compared, with the exception of the U.S. Highway 63 bridge crossing the South Skunk River near Oskaloosa (site 11), where bridge-opening cross sections for the upstream side of the bridge were compared. At five of the bridges, the historic bridge-geometry elevations obtained from the bridge-situation plans did not match the bridge-geometry elevations surveyed during 1994. Discrepancies in bridge-geometry elevations were resolved to the extent possible using bridge-deck and low-steel reference elevations common to both the historic and 1994 


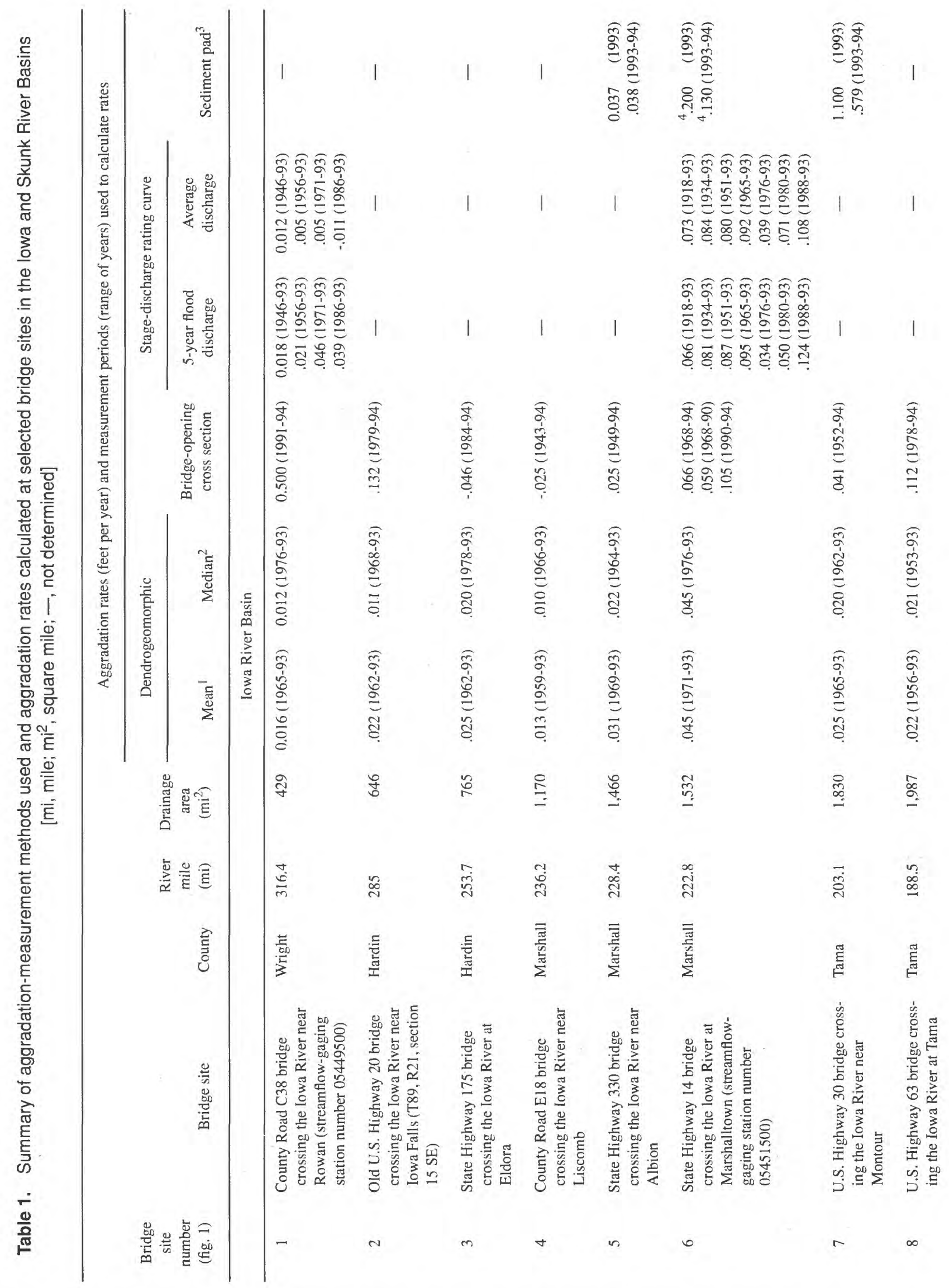




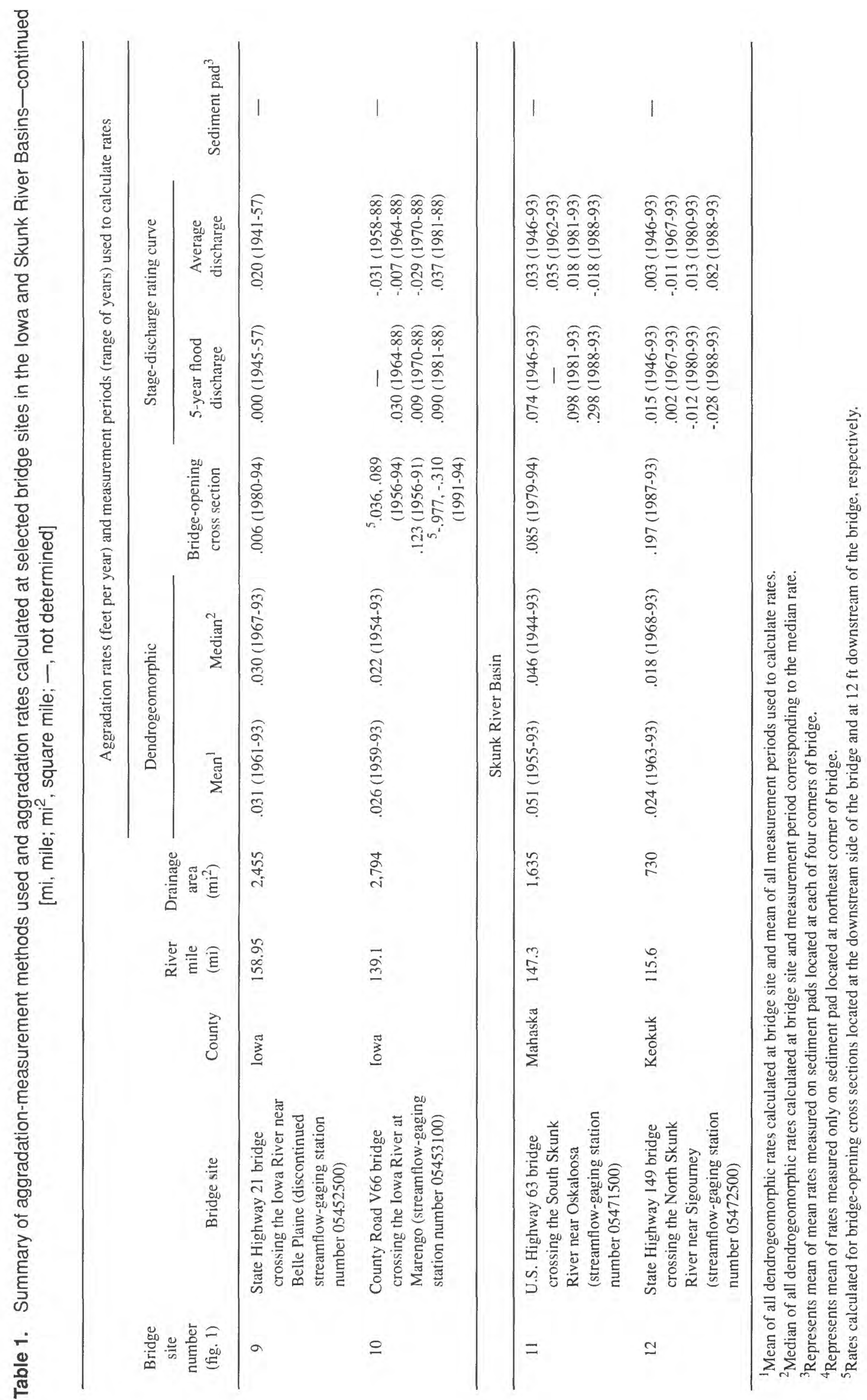


data to adjust the historic cross-section and bridgegeometry elevations. Bridges where elevation adjustments were required are noted in the section "Aggradation Measurements at Selected Bridge Sites in the Iowa and Skunk River Basins."

Cross-sectional areas for both historic and recent bridge cross sections were computed for the bridge-opening area under either the design highwater or extreme high-water elevation as noted on each bridge-situation plan. The historic and recent high-water cross-sectional areas were each divided by their respective high-water bridge-opening widths to determine average historic and recent high-water bridge-opening depths. Dividing the difference between the average historic and recent high-water bridge-opening depths by the period, in years, between the times of the two cross sections, yields an estimate of the average rate of aggradation at the bridge opening since the bridge was constructed. Measurement periods used in the bridge-opening cross-section analyses ranged in length from 3 to 51 years.

Differences between historic and recent bridgeopening cross-sectional areas at a bridge site might indicate changes in the flow capacity of the bridge opening. Discharge through a width contraction, such as a bridge opening, can be expressed as (Matthai, 1967, p. 1):

$$
\mathrm{Q}=\mathrm{C} A_{\mathrm{c}}\left[2 \mathrm{~g}\left(\Delta \mathrm{h}+\alpha_{\mathrm{A}} \mathrm{V}_{\mathrm{A}}^{2} / 2 \mathrm{~g}-\mathrm{h}_{\mathrm{f}}\right)\right]^{0.5}
$$

where $\mathrm{Q}$ is discharge, in $\mathrm{ft}^{3} / \mathrm{s}$;

$\mathrm{C}$ is a coefficient of discharge, dimensionless;

$A_{c}$ is the cross-sectional area at the minimum section parallel to the constriction between the abutments and is the area below the elevation of the water surface, in $\mathrm{ft}^{2}$;

$\mathrm{g}$ is a gravitational constant (acceleration), in $\mathrm{ft} / \mathrm{sec}^{2}$; $\Delta h$ is the difference in elevation of water surface

between the approach section and the minimum section, in $\mathrm{ft}$;

$\alpha_{A}$ is a coefficient which takes into account the variation in velocity at the approach section, dimensionless;

$\mathrm{V}_{\mathrm{A}}$ is the average velocity in the approach section, in $\mathrm{ft} / \mathrm{sec}$; and

$\mathrm{h}_{\mathrm{f}}$ is the friction-head loss between the approach section and the minimum section, in $\mathrm{ft}$.

Since the discharge through a bridge opening is proportional to the area of flow through the opening, increases or decreases in the available cross-sectional area within the bridge opening will tend to increase or decrease the discharge capacity of the opening for a given $\Delta \mathrm{h}$.

\section{Stage-Discharge Rating-Curve Analyses}

Stage-discharge rating-curve analyses were used to quantify average floodway (flood plain and channel) and channel aggradation rates at 6 of the 12 selected bridge sites with USGS streamflow information (fig. 1, table 1). Streamflow information for the period of record was available from active, continuous-record streamflow-gaging stations located at five of these six bridge sites through the 1993 water year. The State Highway 21 bridge crossing the Iowa River near Belle Plaine is the site of a discontinued gaging station, for which streamflow information only was available for the period of record through the 1959 water year.

A stage-discharge rating curve describes a relation between the stage of a river (elevation of the water surface relative to a fixed datum) and the discharge (streamflow) in the river. A curve is developed by measuring the discharge at various stages, graphing the stage versus discharge, and drawing a best-fit curvilinear line through the points. The accuracy of the rating curve is verified at regular intervals by making additional stage-discharge measurements. When additional measurements begin to plot consistently off the curve, a new rating curve is developed. Consistent shifts of the rating curve indicate a change in flow conditions at the site that might be due to changes in the size, slope, roughness, alignment, constrictions and expansions, and shape of the channel (Kennedy, 1984, p. 2). The procedures used by the USGS for developing rating curves are documented by Kennedy (1984).

The chronology of rating curves for a streamflow-gaging station presents the opportunity to estimate changes in the elevation of the streambed. The average elevation of the streambed is defined as the elevation of the water surface (stage) minus the average depth of flow: The average depth of flow is the flow area of the channel cross section divided by the width of the stream at the water surface. As new rating curves are developed at a site, the beginning date of each curve establishes a point in time of the elevation of the water surface corresponding to an index discharge. Generally, changes in the stage corresponding to an index discharge imply a similar change in the elevation of the streambed (Fischer, 1995, p. 13). 
Stage-discharge rating-curve analyses were performed using several index discharges. The average discharge for the period of record was selected as an index discharge for investigating channel-aggradation rates. The average discharge is within banks of most rivers, is a common descriptive statistic of discharge, is readily obtained from discharge records, and is typically within the domain and range of rating curves. Theoretical flood-frequency discharges, having recurrence-intervals of $2,5,10,25,50$, and 100 years, also were selected as index discharges to determine floodway-aggradation rates. In this report, the term floodway refers to the channel and those parts of the flood plain adjoining the channel, which are required to carry and discharge the floodwaters of a river for a given floodflow (Erbe and Flores, 1957, p. 443). Because many of the higher recurrence-interval discharges were outside of the range of many of the rating curves developed for several of the sites, their use to analyze floodway-aggradation rates was limited. Of the lower recurrence-interval discharges, the 5-year flood discharge was selected to estimate floodwayaggradation rates because it represents overbank flow for most rivers and is typically within the range of the rating curves developed for these sites.

Dividing the difference between gage heights determined from current and historic rating curves for an index discharge (average discharge or theoretical 5year flood discharge) by the period between the beginning dates of the rating curves (beginning water year of the current rating curve minus the beginning water year of the historic rating curve), yields an estimate of the average rate of aggradation (channel aggradation or floodway aggradation) during the period. Measurement periods used in the stage-discharge rating-curve analyses ranged in length from 5 to 75 years. Measurement periods analyzed for these bridge sites were selected on the basis of historic rating curves that appeared to have been well defined.

\section{Sediment Pads}

Sediment pads were used to collect information on flood-plain aggradation rates for 1993 and for the period 1993-94 at three selected bridge sites on the Iowa River in the vicinity of Marshalltown: State Highway 330 near Albion, State Highway 14 at Marshalltown, and U.S. Highway 30 near Montour (fig. 1, sites 5-7). Sediment pads were installed on the flood plain at least one bridge-length away from each of the four corners of the bridge, where low-velocity flows were likely during overbank flooding. To install a sediment pad, the ground was first cleared of debris to expose the soil surface and a white-powdered feldspar clay was poured on the surface and troweled smooth to form a 3-ft diameter circle to a depth of about 2 in. (Hupp and Bazemore, 1991, p. 4 42). The clay absorbs moisture from the ground and hardens to become a fixed marker layer, or sediment pad, which simulates natural soil in retaining deposited sediment. A total of 10 sediment pads were installed among the three Iowa River bridge sites during March 25-26, 1993, just prior to overbank flooding. Pads were installed near all four corners of the State Highway 330 and U.S. Highway 30 bridges, and near both downstream corners of the State Highway 14 bridge. Overbank flooding on the morning of March 26 prevented the installation of sediment pads near the upstream corners of the State Highway 14 bridge.

The State Highway 14 bridge crossing the Iowa River at Marshalltown is the site of the Iowa River at Marshalltown streamflow-gaging station (station number 05451500; fig. 1, site 6). Thirteen feet is the flood stage and bankfull stage established by the National Weather Service for this gaging station (information provided by Mike Longnecker, National Weather Service, written commun., February 1995). Streamflow records for this gaging station indicate overflow of the north bank at a stage of $13 \mathrm{ft}$. Figure 3 shows instantaneous gage heights for the Iowa River at Marshalltown for the period March 24, 1993, to November 30, 1994. During the period March 25 to September 27, 1993, gage heights for the Iowa River at Marshalltown exceeded the 13-ft flood stage during 171 days of this 187-day period, indicating the length of time the sediment pads might have been inundated. Due to differences in channel and flood-plain conditions at each of the three bridge sites where the pads were installed, overbank flooding of the Iowa River at Marshalltown at a 13-ft stage might not indicate similar overbank flooding at another location. The 13-ft stage shown on figure 3 provides only an indication of the possible beginning of overbank flooding at the sediment pad locations. During October 1993, after the floodwaters receded, 9 of the 10 sediment pads were recovered and sediment-deposition depths over the pads were measured. The pad installed near the southeast corner of the State Highway 14 bridge was scoured away during the flood. 


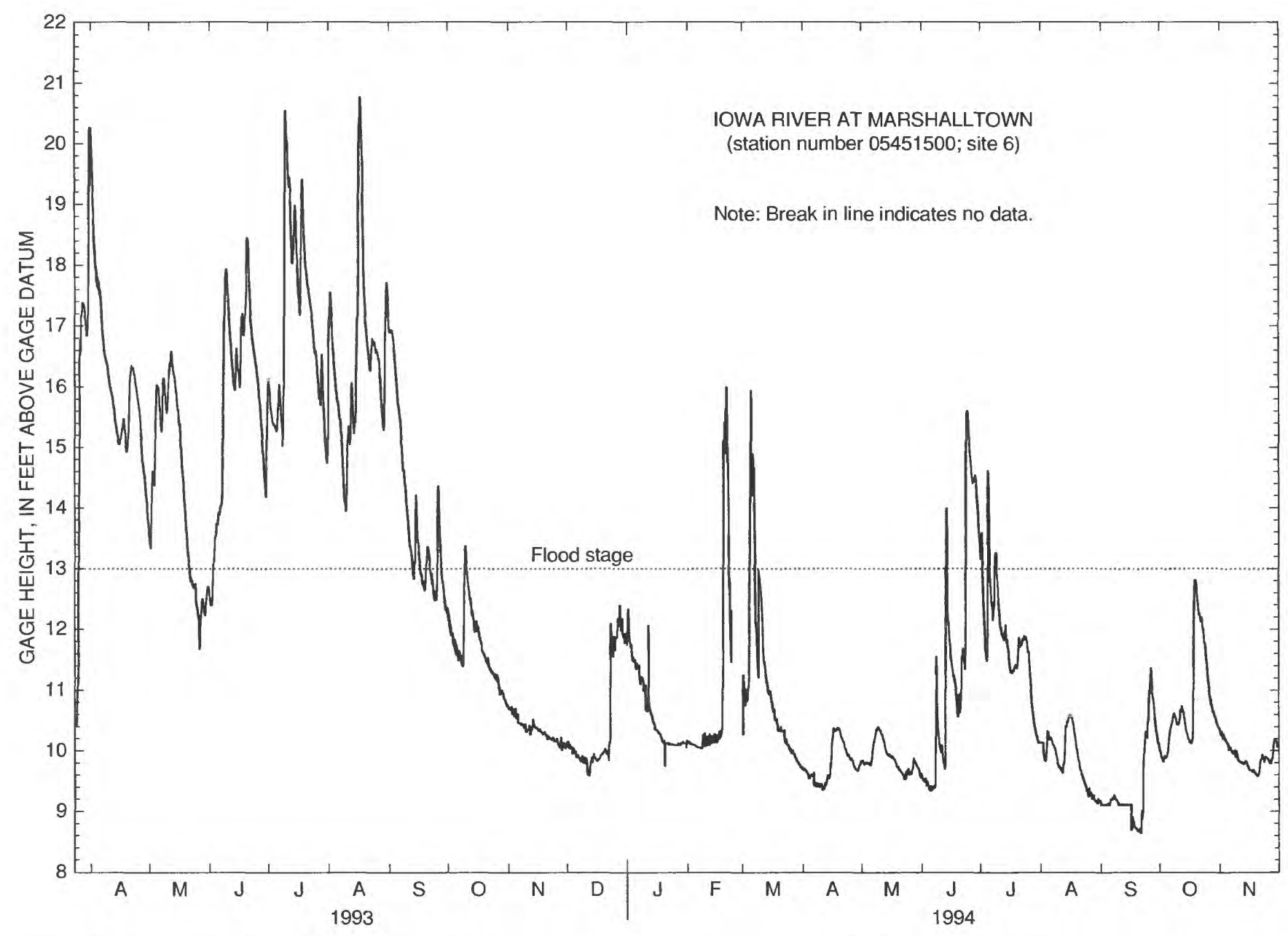

Figure 3. Instantaneous gage heights for the lowa River at Marshalltown, lowa, for the period March 24, 1993, to November 30, 1994.

Figure 4 shows sequences of photographs taken at two of the sediment-pad sites on the Iowa River; figures $4 \mathrm{~A}, 4 \mathrm{C}$, and $4 \mathrm{E}$ show the pad installed near the northeast corner of the State Highway 14 bridge at Marshalltown (site 6 ) and figures $4 B, 4 D$, and $4 F$ show the pad installed near the southeast corner of the U.S. Highway 30 bridge near Montour (site 7). Figures 4A and $4 \mathrm{~B}$ show the sediment pads following installation on March 25, 1993, prior to overbank flooding on March 26; figures 4C and 4D show recovery of the sediment pads during October 1993, following recession of floodwaters; and figures $4 \mathrm{E}$ and $4 \mathrm{~F}$ show depth of sediment deposited on the pads as a result of the 1993 flood.

On May 5, 1994, a sediment pad was reinstalled near the southeast corner of the State Highway 14 bridge and pads also were installed near both upstream corners of the bridge. Figure 3 shows that gage heights for the Iowa River at Marshalltown dur- ing 1994 indicate that overbank flooding might have occurred during a few days in February, March, June, and July. An inspection of all 12 sediment pads on November 30, 1994, indicated that little to no additional sediment was deposited on the pads during 1994.

\section{APPLICATION AND LIMITATIONS OF AGGRADATION-MEASUREMENT METHODS}

Dendrogeomorphic analyses are applicable for most sites where buried flood-plain trees are available for measurement. Dendrogeomorphic analyses estimate aggradation rates from the amount of sediments measured at a particular time, without regard to when the sediments were deposited (Phipps and others, 1995 , p. 7). These calculated aggradation rates actu- 


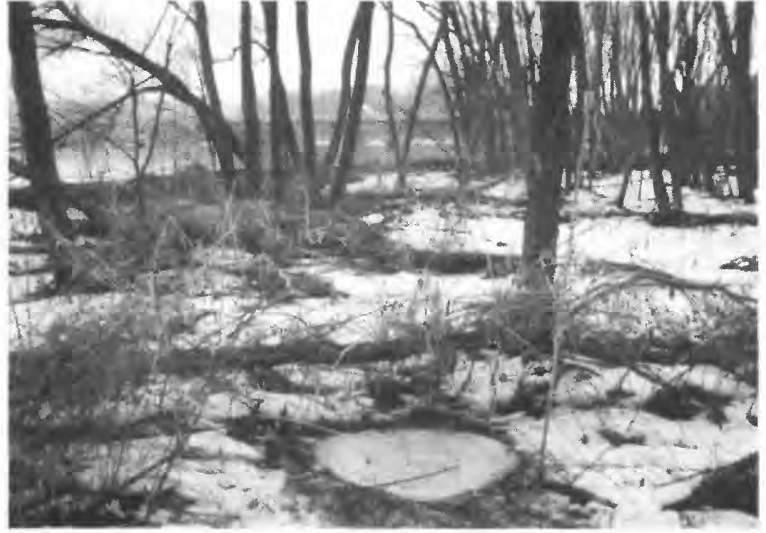

A. State Highway 14 bridge at Marshalltown (site 6)

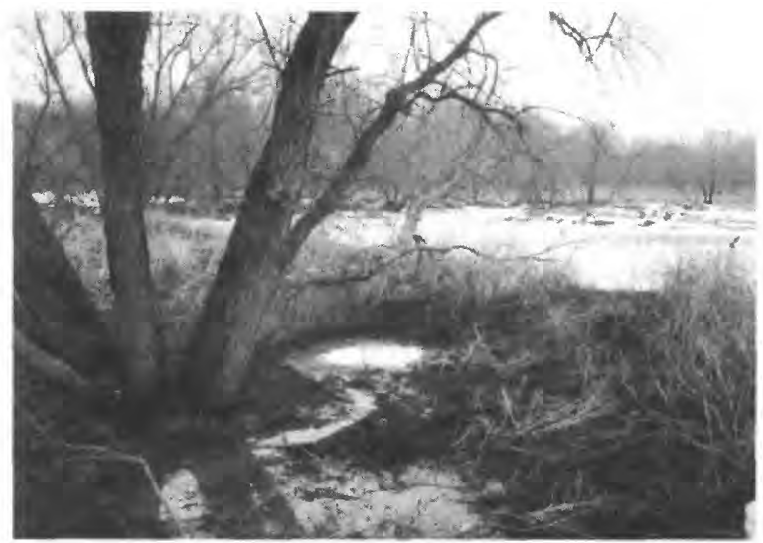

B. U.S. Highway 30 bridge near Montour (site 7)

Installation of sediment pads on left downstream side of bridges on March 25, 1993

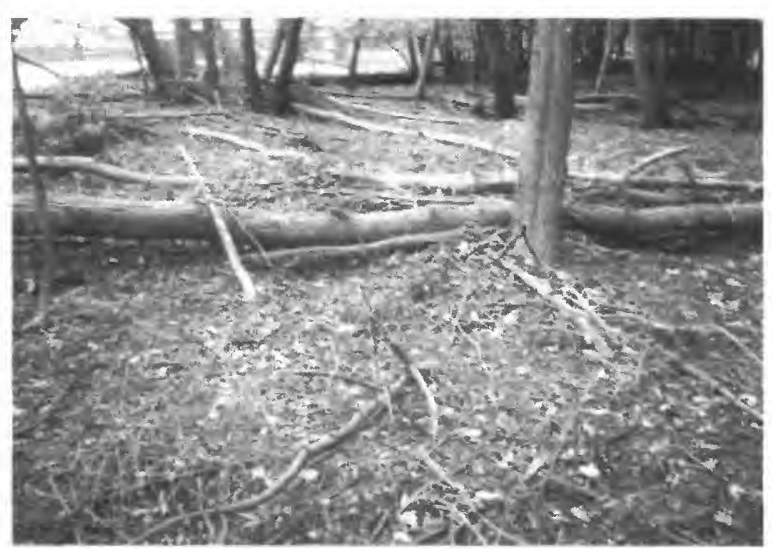

C. State Highway 14 bridge at Marshalltown (site 6)

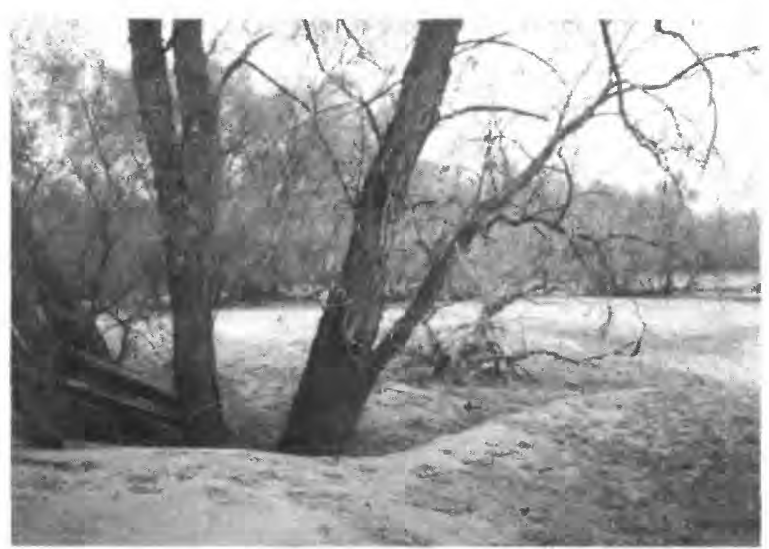

D. U.S. Highway 30 bridge near Montour (site 7)

Recovery of sediment pads following the flood during October, 1993

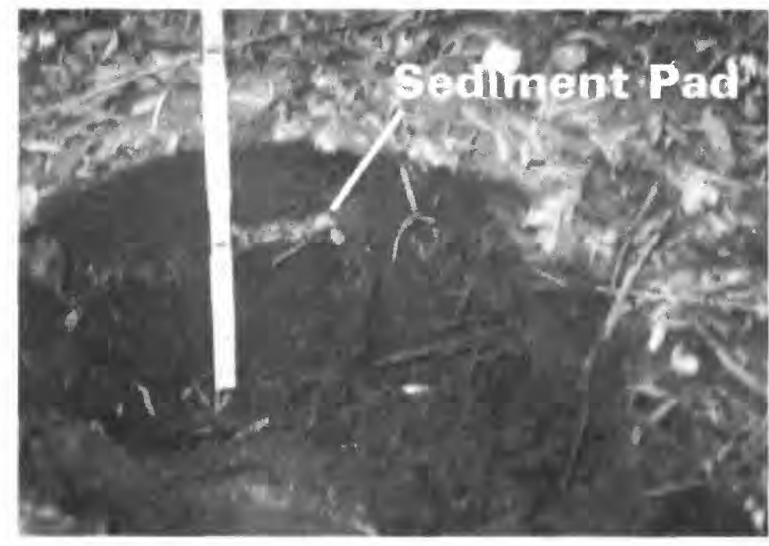

E. State Highway 14 bridge at Marshalltown (site 6)

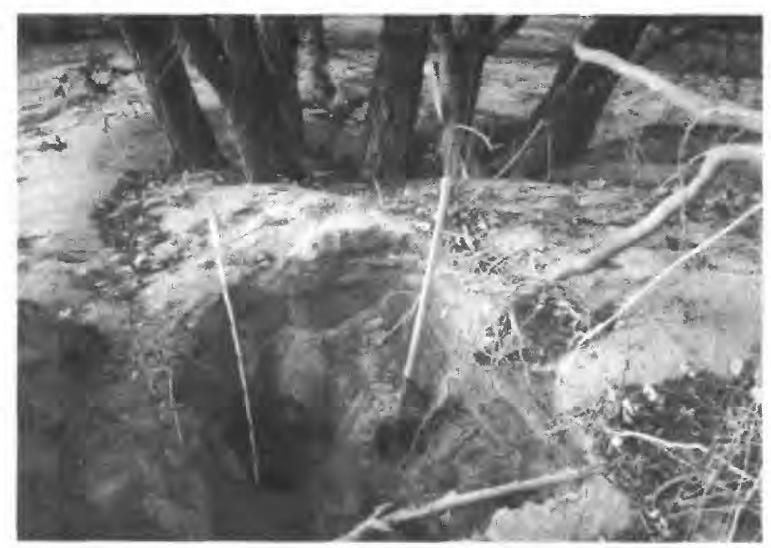

F. U.S. Highway 30 bridge near Montour (site 7)

Depth of sediments deposited on pads during the 1993 flood

Figure 4. Sediment pads before and after flooding and depth of sediments deposited on pads during the 1993 flood at two bridge sites on the lowa River. 
ally represent an average of individual net aggradation rates accumulated since germination of the tree, without consideration of when the sediments were deposited. Sediment deposition is episodic and the sediments could have been in place for decades or could have been deposited during the 1993 flood prior to sampling. Sediments deposited during the 1993 flood might have increased some of the aggradationrate estimates calculated in this study, compared to rates that might have been calculated had sedimentdeposition depths been measured prior to that flood.

Bridge-opening cross-section analyses are applicable at bridge sites where historic cross-sectional information is available. Bridge-opening crosssection analyses do not provide direct measurements of flood-plain or channel aggradation because bridge crossings typically create constrictions during overbank flows. The bridge-opening section or the contracted section framed by the bridge abutments and the channel bed represents a unique hydraulic condition during overbank flows that differs significantly (due to a drop in the water-surface elevation, higher velocities, and greater turbulence) from natural flood-plain and channel conditions away from a bridge.

Bridge-opening cross-section analyses estimate aggradation rates from differences between historic cross sections and recent cross sections surveyed at a particular time, without regard to when differences between the cross sections developed. These calculated aggradation rates actually represent net aggradation rates accumulated during the period between the historic and recent cross sections. Sediment deposition and scour is episodic and differences between historic and recent cross sections could have occurred years earlier or could have occurred during the 1993 flood prior to the transit survey. Scour or deposition from the 1993 flood might have affected some of the bridgeopening aggradation rates calculated in this study, compared to rates that might have been calculated had recent cross sections been surveyed prior to that flood. Bridge-opening aggradation rates calculated in this study also could have been affected if historic bridgeopening cross sections were not excavated to the dimensions shown in the bridge-situation plans or if recent cross sections were surveyed during a time of channel adjustment following activities such as bridge or road construction.

Stage-discharge rating-curve analyses are only applicable at streamflow-gaging stations with a chronology of stage-discharge rating curves. The rating- curve method can use a chronology of stage-discharge rating curves to provide specific information on changes in stage for selected time periods. While changes in stage typically result from deposition or scour of the streambed and flood plain, other changes in channel and flood-plain conditions, such as changes in width, slope, roughness, alignment, constrictions and expansions, and shape, also can result in a change in stage for a specific discharge (Kennedy, 1984, p. 2). At four of the five bridge sites with active gaging stations (sites 1, 6, 11, and 12), the current rating curve used in the analyses had a beginning date in water year 1993. Because the beginning date for each of these rating curves was October 1, 1992, these rating curves were in effect before the start of the 1993 flood and aggradation rates calculated for these sites using stagedischarge rating-curve analyses were not affected by the 1993 flood.

The sediment-pad method is applicable for most flood-plain sites where pads can remain undisturbed for a runoff season or longer and where they are likely to be inundated by low-velocity flows. To obtain accurate estimates of average flood-plain aggradation rates, many sediment pads would need to be installed at various locations on the flood plain prior to an overbank event. Because overbank flooding might not occur every year, sediment pads might need to be left out in the field for more than one runoff season before sediment-deposition measurements are obtained. Longerterm monitoring of sediment pads would determine the annual variability of sediment deposition on a flood plain.

Each of the four aggradation-measurement methods used in this study is useful for obtaining specific types of aggradation information, and for this reason, each method is considered to be applicable for collecting specific types of aggradation data for use in regional or statewide investigations. The rating-curve method might provide the most useful information concerning flood-plain and channel aggradation, but a drawback of this method is that rating-curve information only is available for a limited number of stream sites. The dendrogeomorphic and sediment-pad methods require field measurements, but these methods are applicable for most flood-plain sites and are not limited to bridge locations. The bridge-opening cross section method provides useful information concerning possible changes in the flow capacity of bridge openings and where in the cross section aggradation has occurred. If historic channel cross sections are avail- 
able for channel sections located away from bridges, this method also could be used to estimate aggradation rates away from bridge locations.

\section{AGGRADATION MEASUREMENTS AT SELECTED BRIDGE SITES IN THE IOWA AND SKUNK RIVER BASINS}

Table 1 summarizes the aggradation rates calculated at each bridge site. For the dendrogeomorphic analyses, both the mean and the median of the aggradation rates calculated for all of the trees sampled at each bridge site are listed table 1 . For the sedimentpad method, the aggradation rates listed in table 1 were calculated for pads located at three of the bridge sites for the period March 25 to mid-October 1993 and for the period March 25, 1993, to November 30, 1994. For the State Highway 330 bridge near Albion (site 5) and for the U.S. Highway 30 bridge near Montour (site 7), the aggradation rates listed in table 1 represent the mean of the mean rates measured from sediment pads located near each of the four corners of the bridges. The aggradation rates listed in table 1 for the State Highway 14 bridge at Marshalltown (site 6) represent the mean of the rates measured only from the sediment pad located near the northeast corner of the bridge.

This section of the report presents information relative to the aggradation measurements made at each bridge site. The dendrogeomorphic analyses are summarized for each bridge site and the sediment-pad measurements are summarized for three bridge sites (sites 5-7) for each corner of the bridge in a table following the discussion for each bridge site. The sites are presented in downstream order for each basin. The terms "left" and "right" used in this report to describe the left or right side of the river are determined as viewed while facing in the downstream direction of the flow of the river.

\section{County Road C38 Bridge Crossing the lowa River near Rowan (Site 1)}

The County Road C38 bridge crosses the Iowa River 3.8 mi northwest of Rowan in Wright County, 10.7 mi downstream from the confluence of the East and West Branches of the Iowa River. This is the site of the Iowa River near Rowan streamflow-gaging station (station number 05449500; fig. 1, site 1). Streamflow records for the periods from October 1940 to September 1976 and from June 1977 to September 1993 were available for use in this study. The datum for the gage is $1,143.35 \mathrm{ft}$ above sea level.

The County Road C38 bridge (fig. 5A) was built in 1991 to replace an old bridge built in 1905. The design high-water elevation for the bridge was $1,157.9$ $\mathrm{ft}$ (gage height $14.55 \mathrm{ft}$ ). Differences in elevation between bridge-opening cross-sections obtained from the IDOT bridge-situation plan and from the 1994 transit survey indicate a decrease in cross-sectional area of 12.9 percent below the design high-water elevation. Figure 5A shows that for the period 1991-94, deposition occurred on both channel banks of the bridge opening, with the greater amount occurring on the right bank. A comparison between cross sections obtained from discharge measurements made in 1944 and 1969 indicates minor change in the bridge-opening. The stage-discharge relation of four selected rating curves (fig. 5B) shows a general trend of increasing gage height for specific discharges and a time series of the 20 rating curves developed for the period of record (fig. 5C) also shows this general trend.

Dendrogeomorphic analyses, bridge site 1

\begin{tabular}{lcccccccc}
\hline & & & & \multicolumn{2}{c}{ Range of } & \multicolumn{2}{c}{$\begin{array}{c}\text { Aggradation rates } \\
\text { (feet per year) }\end{array}$} \\
$\begin{array}{c}\text { Location } \\
\text { relative } \\
\text { to bridge }\end{array}$ & $\begin{array}{c}\text { Number } \\
\text { of } \\
\text { samples }\end{array}$ & $\begin{array}{c}\text { Dominant } \\
\text { sediment } \\
\text { type } \\
\text { sampled }\end{array}$ & $\begin{array}{c}\text { seposition } \\
\text { depths } \\
(\mathrm{ft})\end{array}$ & $\begin{array}{c}\text { Tree } \\
\text { ages } \\
\text { (years) }\end{array}$ & Range & Mean & Median \\
\hline Left upstream & 5 & silt/clay & $0.20-.91$ & $9-87$ & $0.010-.042$ & 0.025 & 0.021 \\
Right upstream & 5 & silt/clay & $.05-.23$ & $17-29$ & $.002-.013$ & .006 & .006 \\
Left downstream & 5 & silt/clay & $.05-.54$ & $12-36$ & $.003-.034$ & .017 & .015 \\
Right downstream & 5 & silt/clay & $.23-.78$ & $15-98$ & $.005-.024$ & .016 & .019 \\
\hline
\end{tabular}



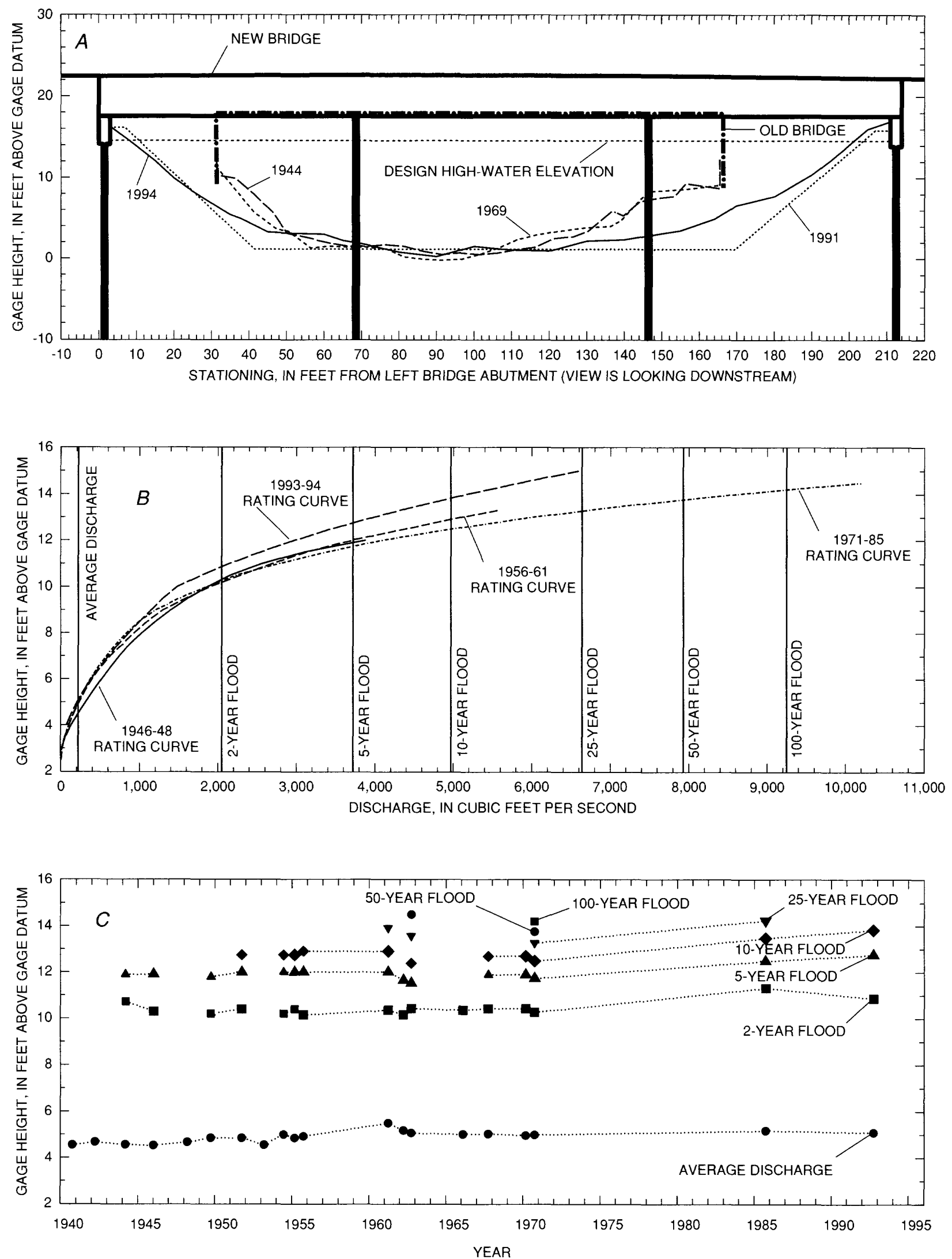

Figure 5. Selected (A) bridge-opening cross sections, $(B)$ stage-discharge rating curves, and $(C)$ time series of rating-curve stages for selected discharges for County Road C38 bridge crossing the lowa River near Rowan, bridge site number 1 (streamflow-gaging station number 05449500). 


\section{Old U.S. Highway 20 Bridge Crossing the lowa River near lowa Falls (Site 2)}

The old U.S. Highway 20 bridge crosses the Iowa River in section 15, T. 89 N., R. 21 W., near the west edge of Iowa Falls in Hardin County (fig. 1, site 2). The old U.S. Highway 20 bridge (fig. 6) was built in 1979. The design high-water elevation for the bridge was 1,073.4 ft above sea level. Differences in elevation between bridge-opening cross-sections obtained from the IDOT bridge-situation plan and from the 1994 transit survey indicate a decrease in cross-sectional area of 15.9 percent below the design high-water elevation. Figure 6 shows that for the period 1979-94, deposition occurred on both channel banks of the bridge opening with the greater amount occurring on the right bank.

\section{State Highway 175 Bridge Crossing the lowa River at Eldora (Site 3)}

The State Highway 175 bridge crosses the Iowa River at the east edge of Eldora in Hardin County (fig. 1, site 3). The State Highway 175 bridge (fig. 7) was built in 1984. The design high-water elevation for the bridge was $952.65 \mathrm{ft}$ above sea level. Differences in elevation between bridge-opening cross-sections obtained from the IDOT bridge-situation plan and from the 1994 transit survey indicate an increase in cross-sectional area of 9.7 percent below the design

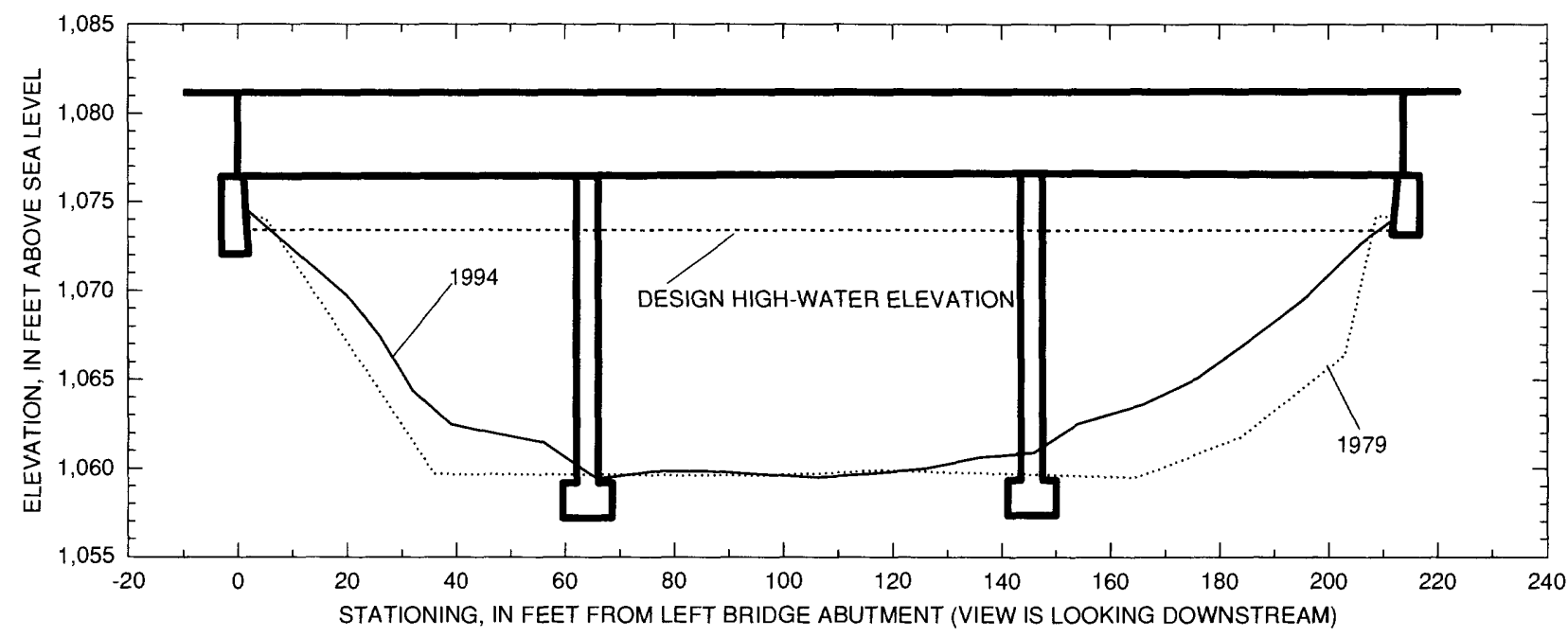

Figure 6. Selected bridge-opening cross sections for old U.S. Highway 20 bridge crossing the lowa River near lowa Falls, bridge site number 2 .

\begin{tabular}{|c|c|c|c|c|c|c|c|}
\hline \multicolumn{8}{|c|}{ Dendrogeomorphic analyses, bridge site 2} \\
\hline \multirow[b]{2}{*}{$\begin{array}{l}\text { Location } \\
\text { relative } \\
\text { to bridge }\end{array}$} & \multirow[b]{2}{*}{$\begin{array}{c}\text { Number } \\
\text { of } \\
\text { samples }\end{array}$} & \multirow{2}{*}{$\begin{array}{c}\text { Dominant } \\
\text { sediment } \\
\text { type } \\
\text { sampled }\end{array}$} & \multicolumn{2}{|c|}{ Range of } & \multicolumn{3}{|c|}{$\begin{array}{l}\text { Aggradation rates } \\
\text { (feet per year) }\end{array}$} \\
\hline & & & $\begin{array}{l}\text { Deposition } \\
\text { depths } \\
(\mathrm{ft})\end{array}$ & $\begin{array}{c}\text { Tree } \\
\text { ages } \\
\text { (years) }\end{array}$ & Range & Mean & Median \\
\hline Left upstream & 5 & sand & $0.16-1.03$ & $13-40$ & $0.006-.041$ & 0.020 & 0.014 \\
\hline Right upstream & 5 & silt/clay & $.13-.58$ & $16-68$ & $.002-.036$ & .014 & .008 \\
\hline Left downstreàm & 5 & silt/clay & $.11-1.31$ & $9-68$ & $.003-.146$ & .040 & .008 \\
\hline Right downstream & 5 & silt/clay & $.24-.40$ & $18-28$ & $.010-.022$ & .013 & .011 \\
\hline
\end{tabular}


high-water elevation. Figure 7 shows that for the period 1984-94, scour occurred across the channel bed and on the right bank.

\section{County Road E18 Bridge Crossing the lowa River near Liscomb (Site 4)}

The County Road E18 bridge crosses the Iowa River about 1.5 mi west of Liscomb in Marshall County (fig. 1, site 4). The County Road E18 bridge (fig. 8) was built in 1943. The extreme high-water elevation for the bridge was $914.1 \mathrm{ft}$ above sea level. Differences in elevation between bridge-opening crosssections obtained from the IDOT bridge-situation plan and from the 1994 transit survey indicate an increase in cross-sectional area of 2.3 percent below the extreme high-water elevation. Figure 8 shows that for the period 1943-94, scour occurred across the channel bed and on the left bank, and deposition occurred on the right bank. Bridge cross-section and geometry elevations obtained from the bridge-situation plan were adjusted by $-4.90 \mathrm{ft}$ to rectify them with high-watermark elevation information obtained for the 1969 flood at this bridge by the USGS and the Marshall County Highway Department (information supplied by Ed Kasper, Marshall County Engineer, written commun., May 1994).

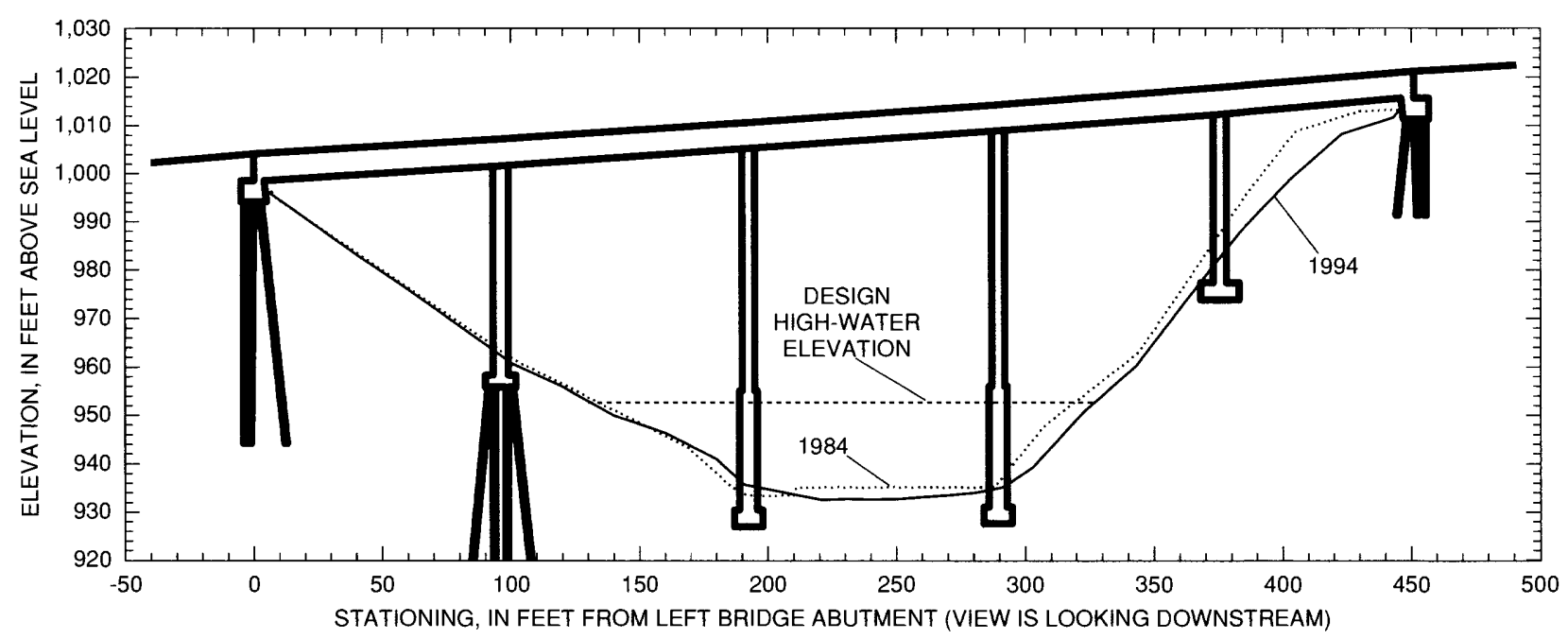

Figure 7. Selected bridge-opening cross sections for State Highway 175 bridge crossing the lowa River at Eldora, bridge site number 3 .

\begin{tabular}{|c|c|c|c|c|c|c|c|}
\hline \multicolumn{8}{|c|}{ Dendrogeomorphic analyses, bridge site 3} \\
\hline \multirow[b]{2}{*}{$\begin{array}{l}\text { Location } \\
\text { relative } \\
\text { to bridge }\end{array}$} & \multirow[b]{2}{*}{$\begin{array}{c}\text { Number } \\
\text { of } \\
\text { samples }\end{array}$} & \multirow{2}{*}{$\begin{array}{l}\text { Dominant } \\
\text { sediment } \\
\text { type } \\
\text { sampled }\end{array}$} & \multicolumn{2}{|c|}{ Range of } & \multicolumn{3}{|c|}{$\begin{array}{l}\text { Aggradation rates } \\
\text { (feet per year) }\end{array}$} \\
\hline & & & $\begin{array}{l}\text { Deposition } \\
\text { depths } \\
\text { (ft) }\end{array}$ & $\begin{array}{c}\text { Tree } \\
\text { ages } \\
\text { (years) }\end{array}$ & Range & Mean & Median \\
\hline Left upstream & 5 & silt/clay & $0.30-.70$ & $15-57$ & $0.012-.025$ & 0.018 & 0.020 \\
\hline Right upstream & 5 & silt/clay & $.12-1.17$ & $29-51$ & $.004-.034$ & .016 & .014 \\
\hline Left downstream & 4 & silt/clay & $.23-.91$ & $18-36$ & $.006-.051$ & .021 & .014 \\
\hline Right downstream & 5 & sand & $.37-2.33$ & $14-63$ & $.026-.082$ & .043 & .037 \\
\hline
\end{tabular}




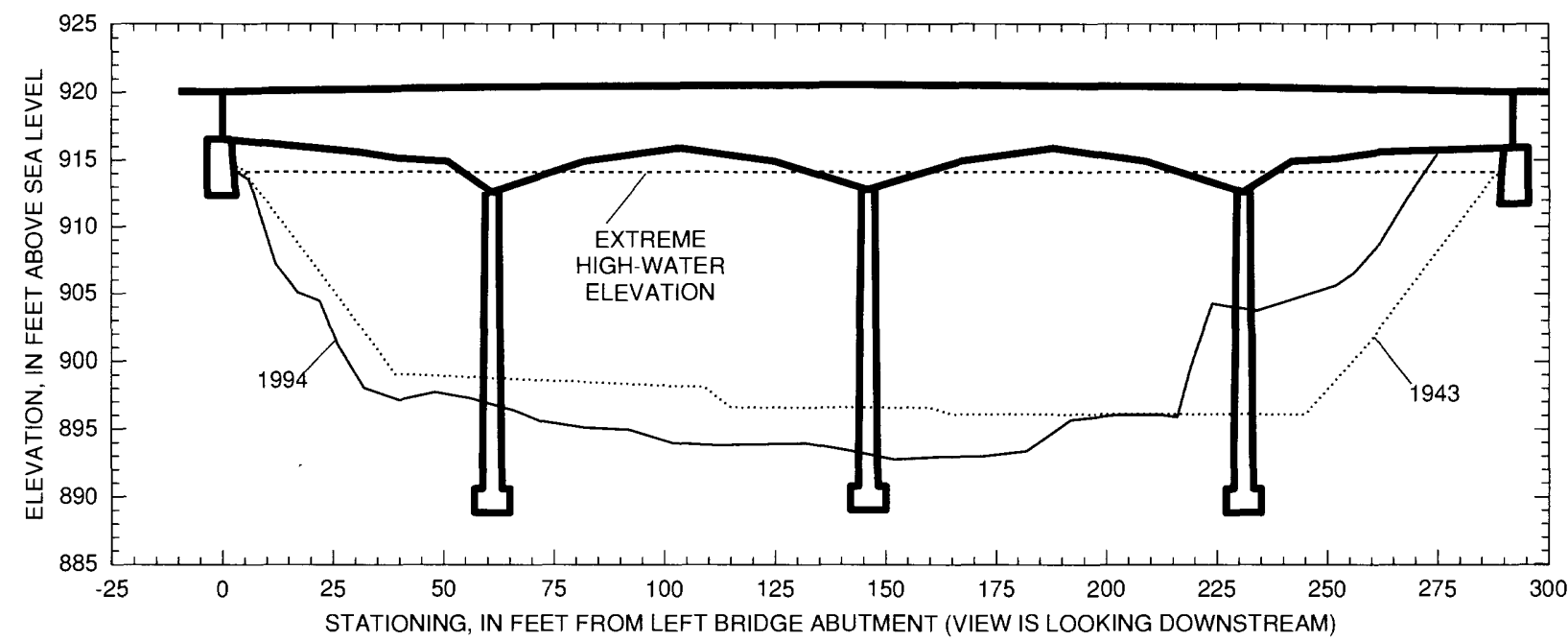

Figure 8. Selected bridge-opening cross sections for County Road E18 bridge crossing the lowa River near Liscomb, bridge site number 4 .

\begin{tabular}{|c|c|c|c|c|c|c|c|}
\hline \multicolumn{8}{|c|}{ Dendrogeomorphic analyses, bridge site 4} \\
\hline \multirow[b]{2}{*}{$\begin{array}{l}\text { Location } \\
\text { relative } \\
\text { to bridge }\end{array}$} & \multirow[b]{2}{*}{$\begin{array}{c}\text { Number } \\
\text { of } \\
\text { samples }\end{array}$} & \multirow{2}{*}{$\begin{array}{l}\text { Dominant } \\
\text { sediment } \\
\text { type } \\
\text { sampled }\end{array}$} & \multicolumn{2}{|c|}{ Range of } & \multicolumn{3}{|c|}{$\begin{array}{l}\text { Aggradation rates } \\
\text { (feet per year) }\end{array}$} \\
\hline & & & $\begin{array}{l}\text { Deposition } \\
\text { depths } \\
\text { (ft) }\end{array}$ & $\begin{array}{c}\text { Tree } \\
\text { ages } \\
\text { (years) }\end{array}$ & Range & Mean & Median \\
\hline Left upstream & 5 & silt/clay & $0.17-.87$ & $26-36$ & $0.005-.029$ & 0.016 & 0.012 \\
\hline Right upstream & 5 & silt/clay & $.05-.51$ & $13-88$ & $.004-.008$ & .006 & .006 \\
\hline Left downstream & 5 & sand & $.19-.71$ & $15-38$ & $.010-.031$ & .020 & .019 \\
\hline Right downstream & 5 & silt/clay & $.23-.51$ & $26-41$ & $.007-.016$ & .011 & .011 \\
\hline
\end{tabular}

\section{State Highway 330 Bridge Crossing the lowa River near Albion (Site 5)}

The State Highway 330 bridge crosses the Iowa River about $1.2 \mathrm{mi}$ southwest of Albion in Marshall County (fig. 1, site 5). The State Highway 330 bridge (fig. 9) was built in 1949. The extreme high-water elevation for the bridge was $886.8 \mathrm{ft}$ above sea level. Differences in elevation between bridge-opening crosssections obtained from the IDOT bridge-situation plan and from the 1994 transit survey indicate a decrease in cross-sectional area of 9.4 percent below the extreme high-water elevation. Figure 9 shows that for the period 1949-94, deposition occurred across much of the channel bed and on the left bank, and scour occurred near the right bank. Bridge cross-section and geometry elevations obtained from the bridge-situation plan were adjusted by $-9.19 \mathrm{ft}$ to rectify them with bridge elevations surveyed during 1994.

\section{State Highway 14 Bridge Crossing the lowa River at Marshalltown (Site 6)}

The State Highway 14 bridge crosses the lowa River at the north edge of Marshalltown in Marshall County. This is the site of the Iowa River at Marshalltown streamflow-gaging station (station number 05451500; fig. 1, site 6). Streamflow records for the periods from October 1902 to September 1903, from October 1914 to September 1927, and from October 1932 to September 1993 were available for use in this study. The datum of the gage is $853.10 \mathrm{ft}$ above sea level. The dendrogeomorphic analyses listed below indicate that upstream rates of flood-plain aggradation are not greater than downstream rates and suggest that backwater effects from the State Highway 14 bridge and causeway have not contributed to increased aggradation on the upstream side of the bridge. Figure $4 \mathrm{E}$ shows the depth of sediments deposited as a result of 


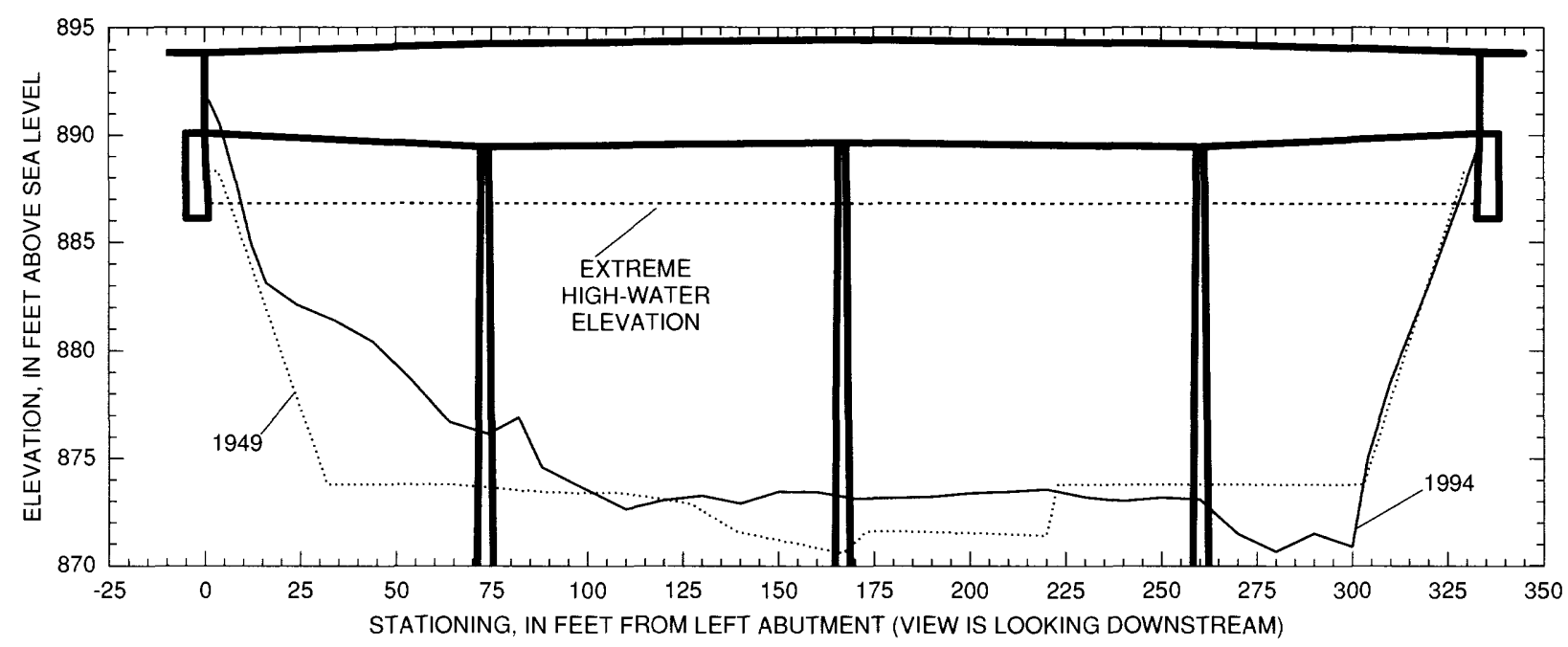

Figure 9. Selected bridge-opening cross sections for State Highway 330 bridge crossing the lowa River near Albion, bridge site number 5 .

\begin{tabular}{|c|c|c|c|c|c|c|c|}
\hline \multicolumn{8}{|c|}{ Dendrogeomorphic analyses, bridge site 5} \\
\hline \multirow[b]{2}{*}{$\begin{array}{l}\text { Location } \\
\text { relative } \\
\text { to bridge }\end{array}$} & \multirow[b]{2}{*}{$\begin{array}{c}\text { Number } \\
\text { of } \\
\text { samples }\end{array}$} & \multirow{2}{*}{$\begin{array}{l}\text { Dominant } \\
\text { sediment } \\
\text { type } \\
\text { sampled }\end{array}$} & \multicolumn{2}{|c|}{ Range of } & \multicolumn{3}{|c|}{$\begin{array}{l}\text { Aggradation rates } \\
\text { (feet per year) }\end{array}$} \\
\hline & & & $\begin{array}{l}\text { Deposition } \\
\text { depths } \\
\text { (ft) }\end{array}$ & $\begin{array}{c}\text { Tree } \\
\text { ages } \\
\text { (years) }\end{array}$ & Range & Mean & Median \\
\hline Left upstream & 6 & silt/clay & $0.38-1.57$ & $18-29$ & $0.016-.060$ & 0.040 & 0.040 \\
\hline Right upstream & 6 & silt/clay & $.30-.97$ & $14-27$ & $.013-.039$ & .024 & .022 \\
\hline Left downstream & 6 & sily/clay & $.30-1.18$ & $11-33$ & $.014-.098$ & .036 & .019 \\
\hline \multirow[t]{3}{*}{ Right downstream } & 6 & silt/clay & $.34-.60$ & $13-33$ & $.016-.046$ & .023 & .018 \\
\hline & \multicolumn{7}{|c|}{ Sediment-pad measurements, bridge site 5} \\
\hline & & & $\begin{array}{c}\text { Measure- } \\
\text { ment } \\
\text { period }\end{array}$ & $\begin{array}{r}R \\
\text { depos }\end{array}$ & $\begin{array}{l}\text { ige of } \\
\text { lon depths } \\
\text { (ft) }\end{array}$ & $\begin{array}{r}\text { Mean } \\
\text { tiol } \\
\text { (feet }\end{array}$ & $\begin{array}{l}\text { ggrada- } \\
\text { rates } \\
\text { er year) }\end{array}$ \\
\hline \multirow[t]{2}{*}{ Left upstream } & 6 & silt/clay & 1993 & & $3-.11$ & & 10 \\
\hline & 6 & & 1993-94 & & $5-.20$ & & 85 \\
\hline \multirow[t]{2}{*}{ Right upstream } & 6 & silt/clay & 1993 & & -.06 & & 04 \\
\hline & 6 & & 1993-94 & & -.12 & & 50 \\
\hline \multirow[t]{2}{*}{ Left downstream } & 3 & silt/clay & 1993 & & -.01 & & 05 \\
\hline & ${ }^{1} 0$ & & $1993-94$ & & -.01 & & 02 \\
\hline \multirow[t]{2}{*}{ Right downstream } & 6 & silt/clay & 1993 & & -.01 & & 04 \\
\hline & 6 & & 1993-94 & & -.03 & & 15 \\
\hline
\end{tabular}

${ }^{1}$ Sediment pad found to be weathered on November 30, 1994, but no additional sediment deposition was apparent for 1994. Sediment-deposition measurements collected for 1993 were also used for the 1993-94 period. 
the 1993 flood on the pad located near the left downstream corner of the bridge.

The bridge shown in figure 10A carries the two northbound lanes of State Highway 14 and was built in 1968 just downstream of an older bridge built in 1934, which after 1968, carried the two southbound lanes of State Highway 14. In 1987, the old upstream bridge was replaced with a new bridge.The extreme highwater elevation for the bridge, shown in figure 10A, was $870.72 \mathrm{ft}$ (gage height $17.62 \mathrm{ft}$ ). Differences in elevation between bridge-opening cross-sections obtained from the IDOT bridge-situation plan and from the 1994 transit survey indicate a decrease in cross-sectional area of 17.5 percent below the extreme high-water elevation. Figure 10A shows that for the period 1968-94, deposition occurred across the majority of the channel bed and on the left bank of the bridge opening, and scour occurred on the right bank of the bridge opening. Differences in elevation between the 1968 and 1994 cross sections indicate that as much as $6 \mathrm{ft}$ of deposition occurred on the left bank. Differences in elevation between the 1968 cross section and a cross section obtained from a discharge measurement made in 1990 (fig. 10A) indicate a decrease in cross-sectional area of 15.8 percent.

The stage-discharge relation of six selected rating curves (fig. 10B) shows a trend of increasing gage height for specific discharges, and a time series of the 44 rating curves developed for the period of record (fig. 11) also shows this trend. Gage heights for these

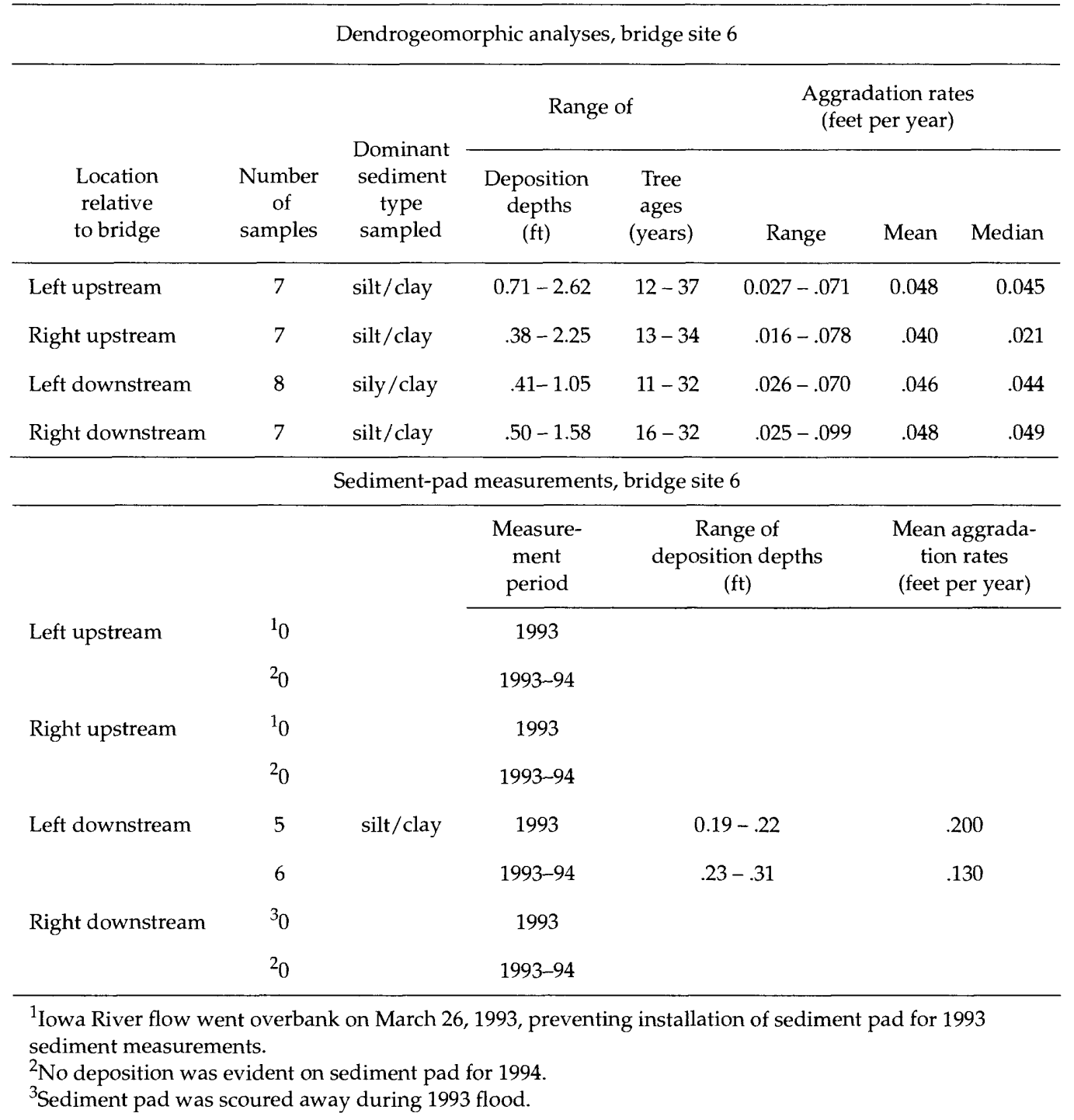



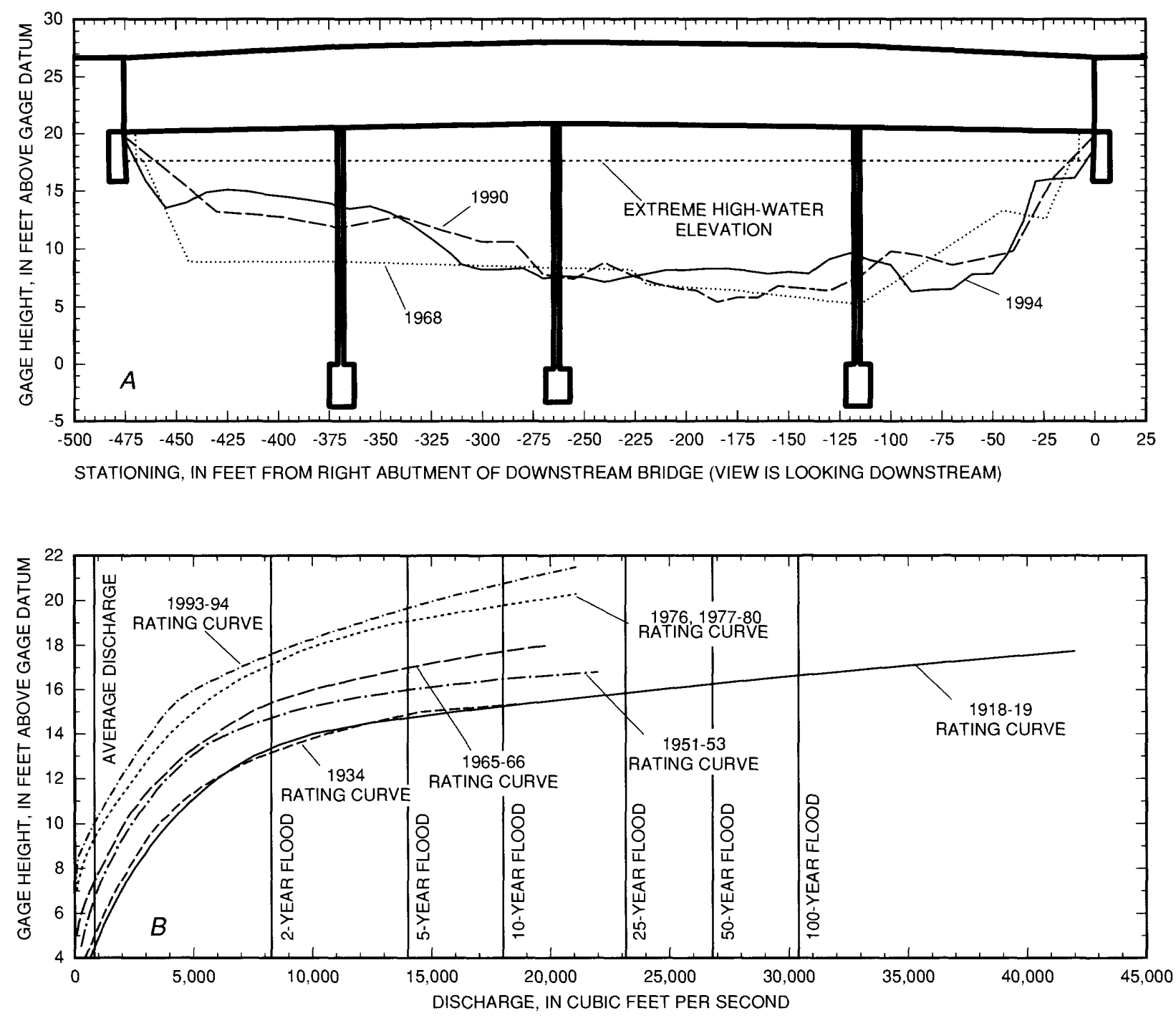

Figure 10. Selected (A) bridge-opening cross sections and (B) stage-discharge rating curves for State Highway 14 bridge crossing the lowa River at Marshalltown, bridge site number 6 (streamflow-gaging station number 05451500 ).

discharges show a greater increase in stage after about 1942. Rating-curve analyses provide specific information on selected time periods of increased stages. For instance, stages for the average discharge increased by $0.7 \mathrm{ft}$ during $1920-33$, by $4.4 \mathrm{ft}$ during $1937-57$, by $2.2 \mathrm{ft}$ during 1965-75, and by $0.9 \mathrm{ft}$ during 1980-92. Likewise, stages for the 5-year flood-frequency discharge increased by $1.5 \mathrm{ft}$ during 1942-54, by $2.6 \mathrm{ft}$ during 1960-73, and by $0.6 \mathrm{ft}$ during 1980-92.

A comparison of the observed stages of selected maximum annual-peak discharges (fig. 11) also illustrates the increase in gage heights during the period of record. Recent floods occurring during 1990, 1991, and 1993 (with discharges of 17,300, 15,200, and $20,400 \mathrm{ft}^{3} / \mathrm{s}$, respectively) had higher stages than past floods with similar discharges. The stages for these three floods were the highest recorded at this gage since at least 1915. The gage height of the low steel of the State Highway 14 bridge ranges between about 20.2 and $20.9 \mathrm{ft}$ (fig. 10A). Gage heights for the 1990, 1991 , and 1993 floods were 20.38, 19.97, and $20.77 \mathrm{ft}$, respectively. These floods were near, or on, the low steel of the bridge; yet computed recurrence intervals for the 1990, 1991, and 1993 flood discharges are approximately 9,6 , and 16 years, respectively. The 1918 flood had a discharge of $42,000 \mathrm{ft}^{3} / \mathrm{s}$, and this flood exceeded the theoretical 100 -year recurrence interval discharge of $30,400 \mathrm{ft}^{3} / \mathrm{s}$ by a factor of 1.38 . The gage height of the 1918 flood was $17.74 \mathrm{ft}$. 


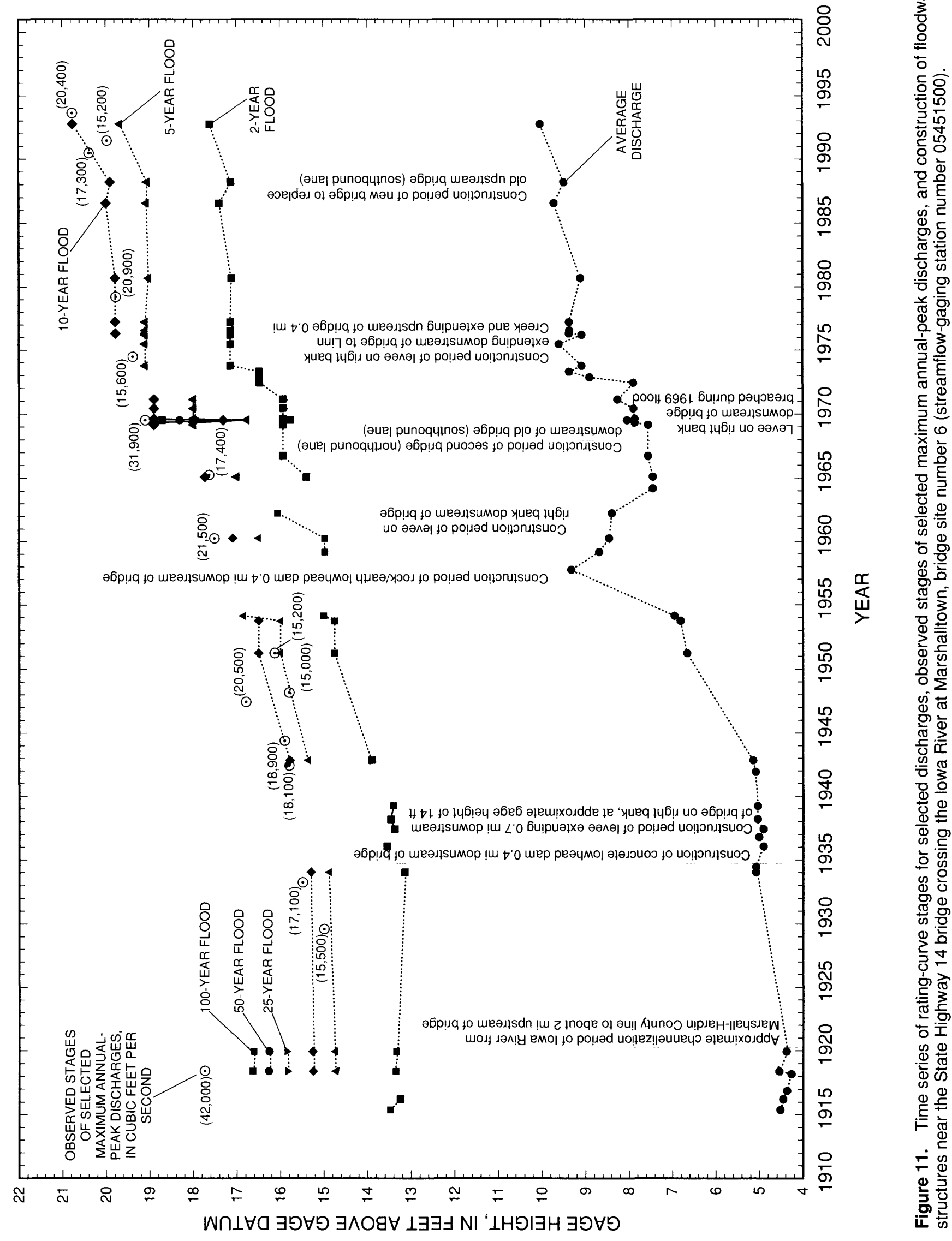




\section{U.S. Highway 30 Bridge Crossing the lowa River near Montour (Site 7)}

The U.S. Highway 30 bridge crosses the Iowa River about 1.3 mi north of Montour in Tama County (fig. 1, site 7). Sediment pads located near the right upstream and left downstream corners of the bridge had large amounts of sand deposited on them during the 1993 flood (see table below). A sand splay was deposited during the flood over an extensive area of the flood plain near the left downstream corner of this bridge. A sediment pad was located near the middle of this sand splay. Figure $4 \mathrm{~F}$ shows the $2.95 \mathrm{ft}$ of sand that was deposited on this sediment pad during the 1993 flood. The U.S. Highway 30 bridge (fig. 12) was built in 1952. The extreme high-water elevation for the bridge was $839.3 \mathrm{ft}$ above sea level. Differences in elevation between bridge-opening cross-sections obtained from the IDOT bridge-situation plan and from the 1994 transit survey indicate a decrease in cross-sectional area of 14.7 percent below the extreme high-water elevation. Figure 12 shows that for the period 1952-94, deposition occurred across the right side of the channel bed and on the right bank of the bridge opening, and scour occurred on the left side of the channel bed and on the left bank of the bridge opening. Bridge cross-section and geometry elevations obtained from the bridge-situation plan were adjusted by $-6.51 \mathrm{ft}$ to rectify them with bridge elevations surveyed during 1994.

Dendrogeomorphic analyses, bridge site 7

\begin{tabular}{|c|c|c|c|c|c|c|c|}
\hline \multirow[b]{2}{*}{$\begin{array}{l}\text { Location } \\
\text { relative } \\
\text { to bridge }\end{array}$} & \multirow[b]{2}{*}{$\begin{array}{c}\text { Number } \\
\text { of } \\
\text { samples }\end{array}$} & \multirow{2}{*}{$\begin{array}{c}\text { Dominant } \\
\text { sediment } \\
\text { type } \\
\text { sampled }\end{array}$} & \multicolumn{2}{|c|}{ Range of } & \multicolumn{3}{|c|}{$\begin{array}{l}\text { Aggradation rates } \\
\text { (feet per year) }\end{array}$} \\
\hline & & & $\begin{array}{l}\text { Deposition } \\
\text { depths } \\
\text { (ft) }\end{array}$ & $\begin{array}{c}\text { Tree } \\
\text { ages } \\
\text { (years) }\end{array}$ & Range & Mean & Median \\
\hline Left upstream & 6 & silt/clay & $0.15-1.16$ & $12-41$ & $0.007-.053$ & 0.024 & 0.019 \\
\hline Right upstream & 6 & $\begin{array}{l}\text { sand/ } \\
\text { silt/clay }\end{array}$ & $.27-1.37$ & $23-62$ & $.010-.028$ & .016 & .014 \\
\hline Left downstream & 6 & silt/clay & $.21-1.64$ & $29-48$ & $.006-.036$ & .018 & .018 \\
\hline Right downstream & 6 & silt/clay & $.08-1.05$ & $11-20$ & $.006-.075$ & .040 & .034 \\
\hline \multicolumn{8}{|c|}{ Sediment-pad measurements, bridge site 7} \\
\hline & & & $\begin{array}{c}\text { Measure- } \\
\text { ment } \\
\text { period }\end{array}$ & $\begin{array}{r}R \\
\text { depos }\end{array}$ & $\begin{array}{l}\text { ge of } \\
\text { on depths } \\
\mathrm{ft} \text { ) }\end{array}$ & $\begin{array}{r}\text { Mean } \\
\text { tio } \\
\text { (feet }\end{array}$ & $\begin{array}{l}\text { ggrada- } \\
\text { rates } \\
\text { er year) }\end{array}$ \\
\hline \multirow[t]{2}{*}{ Left upstream } & 7 & silt/clay & 1993 & & -.19 & & 16 \\
\hline & 6 & & 1993-94 & & -.14 & & 155 \\
\hline \multirow[t]{2}{*}{ Right upstream } & 3 & sand & 1993 & & -1.27 & & 20 \\
\hline & 6 & & 1993-94 & & -1.46 & & 715 \\
\hline \multirow[t]{2}{*}{ Left downstream } & 8 & sand & 1993 & & -3.05 & & .95 \\
\hline & 6 & & 1993-94 & & -3.1 & & .49 \\
\hline \multirow[t]{2}{*}{ Right downstream } & 6 & silt/clay & 1993 & & -.10 & & 09 \\
\hline & 6 & & $1993-94$ & & -.13 & & 55 \\
\hline
\end{tabular}




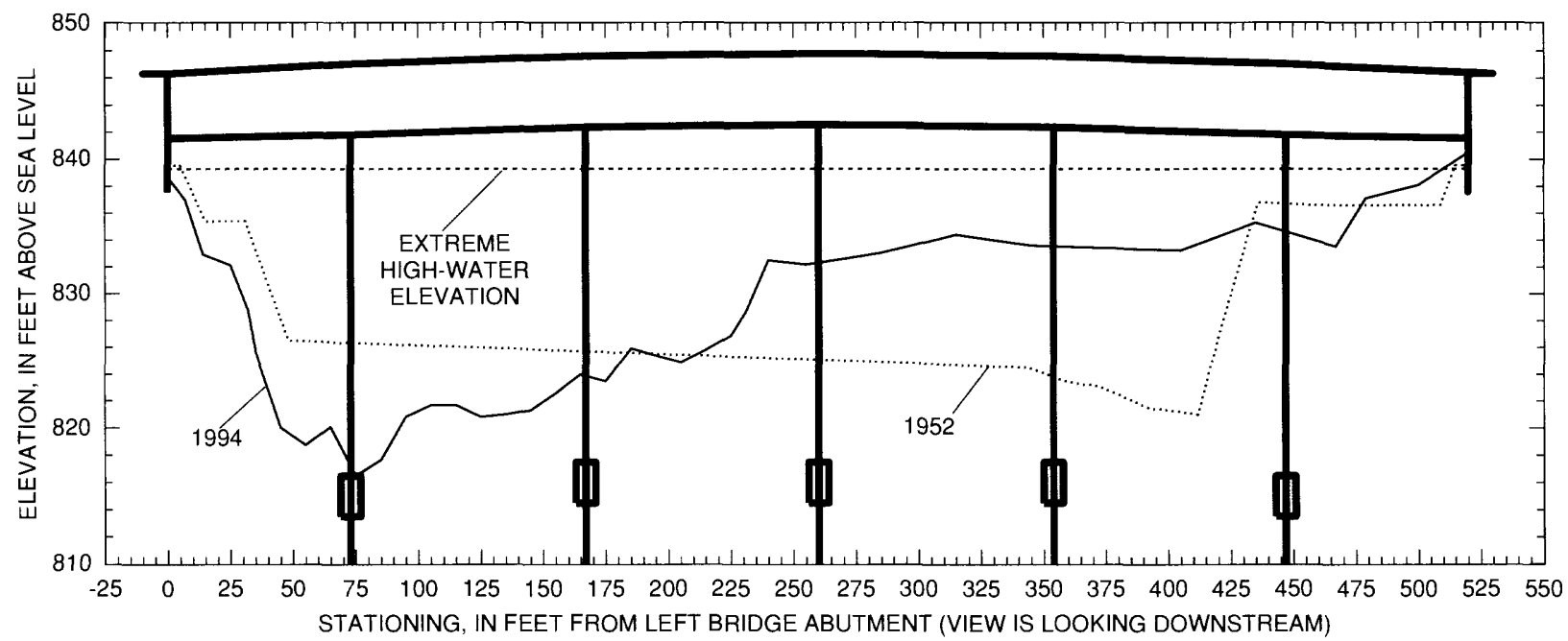

Figure 12. Selected bridge-opening cross sections for U.S. Highway 30 bridge crossing the lowa River near Montour, bridge site number 7 .

\section{U.S. Highway 63 Bridge Crossing the lowa River at Tama (Site 8)}

The U.S. Highway 63 bridge crosses the Iowa River at the south edge of Tama in Tama County (fig. 1, site 8). The U.S. Highway 63 bridge (fig. 13) was built in 1978. The design high-water elevation for the bridge was $817.5 \mathrm{ft}$ above sea level. Differences in elevation between bridge-opening cross-sections obtained from the IDOT bridge-situation plan and from the 1994 transit survey indicate a decrease in cross-sectional area of 16.0 percent below the design high-water elevation. Figure 13 shows that for the period 1978-94, deposition occurred on both the left and right banks of the bridge opening, and scour occurred across most of the channel bed of the bridge opening.

\section{State Highway 21 Bridge Crossing the lowa River near Belle Plaine (Site 9)}

The State Highway 21 bridge crosses the Iowa River about 2.7 mi south of Belle Plaine in Iowa County. This is the site of a discontinued streamflowgaging station, the lowa River near Belle Plaine (station number 05452500; fig. 1, site 9). Streamflow records for the period September 1939 to September 1959 were available for use in this study. The datum of the gage is $749.82 \mathrm{ft}$ above sea level.

The State Highway 21 bridge (fig. 14A) was built in 1980. The design high-water elevation for the bridge was $769.0 \mathrm{ft}$ (gage height $19.2 \mathrm{ft}$ ). Differences in elevation between bridge-opening cross-sections obtained from the IDOT bridge-situation plan and from the 1994 transit survey indicate a decrease in

\begin{tabular}{|c|c|c|c|c|c|c|c|}
\hline \multicolumn{8}{|c|}{ Dendrogeomorphic analyses, bridge site 8} \\
\hline \multirow[b]{2}{*}{$\begin{array}{l}\text { Location } \\
\text { relative } \\
\text { to bridge }\end{array}$} & \multirow[b]{2}{*}{$\begin{array}{c}\text { Number } \\
\text { of } \\
\text { samples }\end{array}$} & \multirow{2}{*}{$\begin{array}{c}\text { Dominant } \\
\text { sediment } \\
\text { type } \\
\text { sampled }\end{array}$} & \multicolumn{2}{|c|}{ Range of } & \multicolumn{3}{|c|}{$\begin{array}{l}\text { Aggradation rates } \\
\text { (feet per year) }\end{array}$} \\
\hline & & & $\begin{array}{l}\text { Deposition } \\
\text { depths } \\
\text { (ft) }\end{array}$ & $\begin{array}{c}\text { Tree } \\
\text { ages } \\
\text { (years) }\end{array}$ & Range & Mean & Median \\
\hline Left upstream & 5 & silt/clay & $0.22-1.09$ & $27-59$ & $0.004-.036$ & 0.017 & 0.013 \\
\hline Right upstream & 5 & silt/clay & $.39-.74$ & $12-46$ & $.011-.034$ & .020 & .020 \\
\hline Left downstream & 5 & silt/clay & $.24-1.95$ & $31-50$ & $.006-.063$ & .025 & .016 \\
\hline Right downstream & 5 & silt/clay & $.28-1.42$ & $22-44$ & $.008-.035$ & .025 & .025 \\
\hline
\end{tabular}




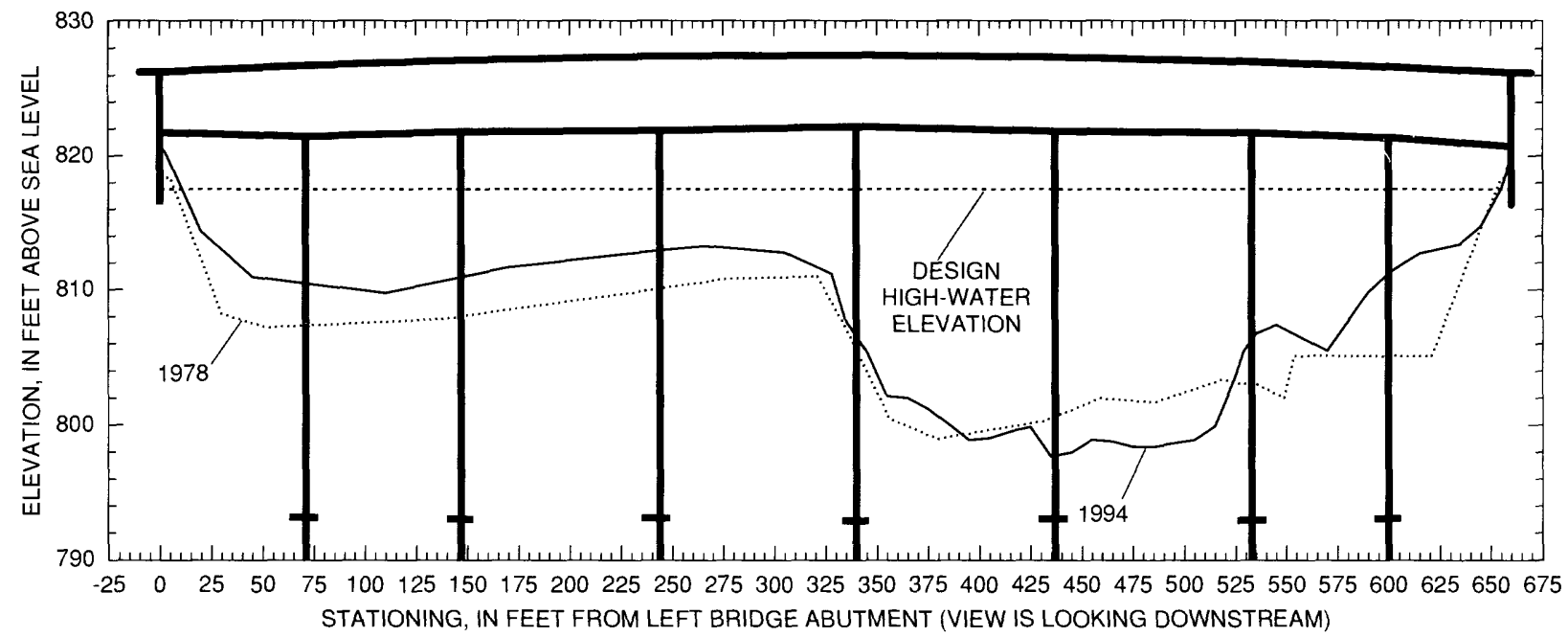

Figure 13. Selected bridge-opening cross sections for U.S. Highway 63 bridge crossing the lowa River at Tama, bridge site number 8.

cross-sectional area of 1.2 percent below the design high-water elevation. Figure 14A shows that for the period 1980-94, deposition occurred on the left and right banks of the bridge opening and across the left side of the channel bed, and scour occurred across the right side of the channel bed. The stage-discharge relation of three selected rating curves (fig. 14B) shows a minor trend of increasing gage height for specific lowflow discharges, and a time series of the 14 rating curves developed for the period 1940-59 (fig. 14C) shows no trend in gage heights. The historic stage-discharge rating-curve information indicates that aggradation during the 1940s and 1950s was minimal. The dendrogeomorphic analyses suggest that flood-plain aggradation might have increased after the streamflow-gaging station was discontinued in 1959.

\section{County Road V66 Bridge Crossing the lowa River at Marengo (Site 10)}

The County Road V66 bridge crosses the Iowa River at the north edge of Marengo in Iowa County. This is the site of the Iowa River at Marengo streamflow-gaging station (station number 05453100; fig. 1, site 10). Streamflow records for the period October 1956 to September 1993 were available for use in this study. The datum of the gage is $720.52 \mathrm{ft}$ above sea level.

The County Road V66 bridge (fig. 15A) was built in 1956. The design high-water elevation for the bridge was $738.65 \mathrm{ft}$ (gage height $18.13 \mathrm{ft}$ ). Differences in elevation between the bridge-opening cross section obtained from the IDOT bridge-situation plan

Dendrogeomorphic analyses, bridge site 9

\begin{tabular}{|c|c|c|c|c|c|c|c|}
\hline \multirow[b]{2}{*}{$\begin{array}{l}\text { Location } \\
\text { relative } \\
\text { to bridge }\end{array}$} & \multirow[b]{2}{*}{$\begin{array}{c}\text { Number } \\
\text { of } \\
\text { samples }\end{array}$} & \multirow{2}{*}{$\begin{array}{c}\text { Dominant } \\
\text { sediment } \\
\text { type } \\
\text { sampled }\end{array}$} & \multicolumn{2}{|c|}{ Range of } & \multicolumn{3}{|c|}{$\begin{array}{l}\text { Aggradation rates } \\
\text { (feet per year) }\end{array}$} \\
\hline & & & $\begin{array}{l}\text { Deposition } \\
\text { depths } \\
\text { (ft) }\end{array}$ & $\begin{array}{c}\text { Tree } \\
\text { ages } \\
\text { (years) }\end{array}$ & Range & Mean & Median \\
\hline Left upstream & 5 & silt/clay & $0.34-1.27$ & $16-36$ & $0.018-.035$ & 0.026 & 0.023 \\
\hline Right upstream & 5 & silt/clay & $.47-1.27$ & $24=55$ & $.009-.053$ & .023 & .016 \\
\hline Left downstream & 5 & silt/clay & $.89-3.35$ & $25-49$ & $.023-.076$ & .042 & .031 \\
\hline Right downstream & 5 & silt/clay & $.53-1.21$ & $19-30$ & $.028-.040$ & .033 & .031 \\
\hline
\end{tabular}



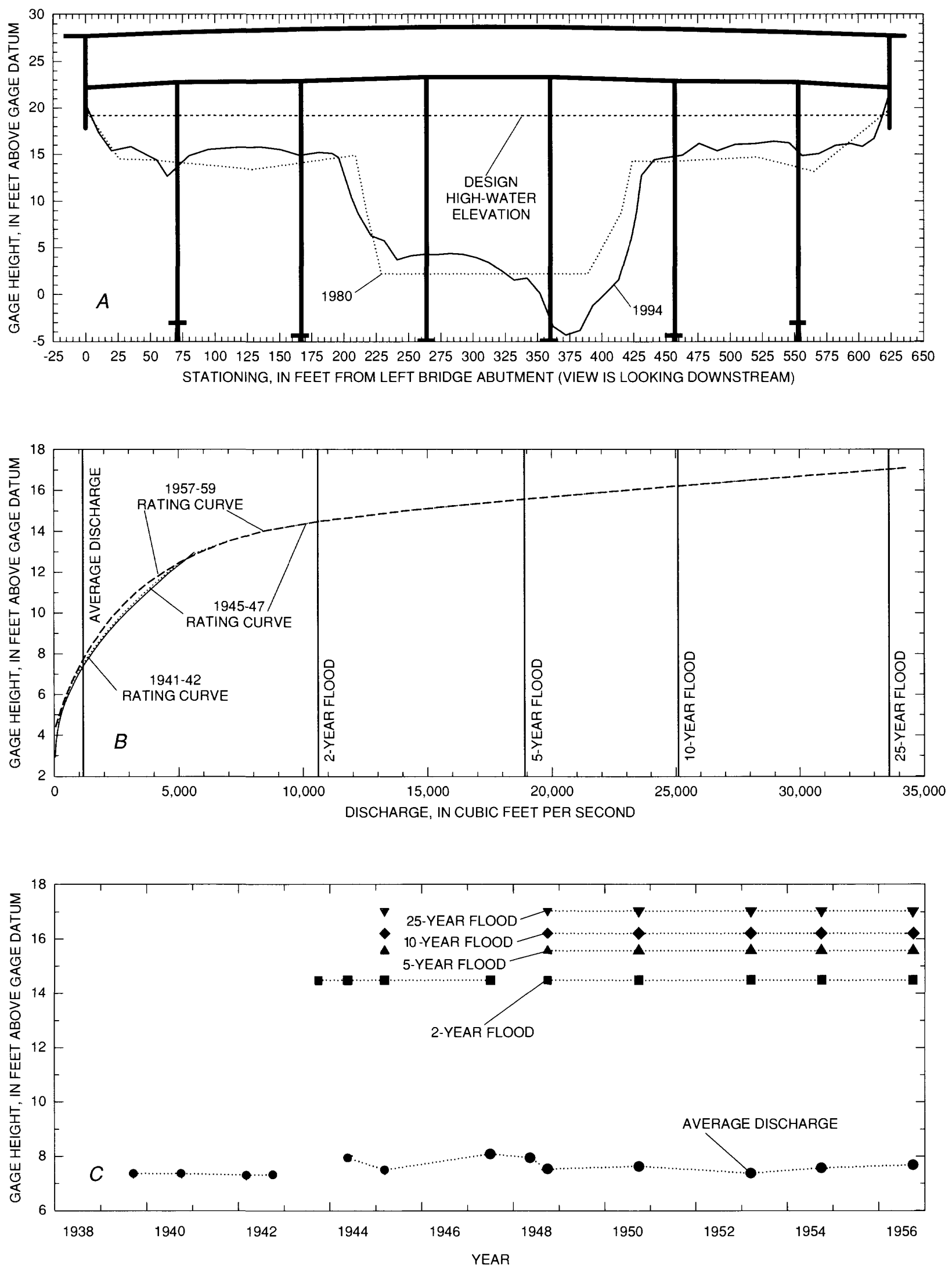

Figure 14. Selected (A) bridge-opening cross sections, (B) stage-discharge rating curves, and (C) time series of rating-curve stages for selected discharges for State Highway 21 bridge crossing the lowa River near Belle Plaine, bridge site number 9 (discontinued streamflow-gaging station number 05452500). 
Dendrogeomorphic analyses, bridge site 10

\begin{tabular}{|c|c|c|c|c|c|c|c|}
\hline \multirow[b]{2}{*}{$\begin{array}{l}\text { Location } \\
\text { relative } \\
\text { to bridge }\end{array}$} & \multirow[b]{2}{*}{$\begin{array}{c}\text { Number } \\
\text { of } \\
\text { samples }\end{array}$} & \multirow{2}{*}{$\begin{array}{l}\text { Dominant } \\
\text { sediment } \\
\text { type } \\
\text { sampled }\end{array}$} & \multicolumn{2}{|c|}{ Range of } & \multicolumn{3}{|c|}{$\begin{array}{l}\text { Aggradation rates } \\
\text { (feet per year) }\end{array}$} \\
\hline & & & $\begin{array}{l}\text { Deposition } \\
\text { depths } \\
\text { (ft) }\end{array}$ & $\begin{array}{c}\text { Tree } \\
\text { ages } \\
\text { (years) }\end{array}$ & Range & Mean & Median \\
\hline Left upstream & 5 & silt/clay & $0.31-1.47$ & $28-50$ & $0.009-.037$ & 0.021 & 0.021 \\
\hline Right upstream & 5 & silt/clay & $.59-1.85$ & $18-41$ & $.018-.062$ & .043 & .048 \\
\hline Left downstream & 5 & silt/clay & $.36-1.01$ & $28-46$ & $.008-.036$ & .019 & .015 \\
\hline Right downstream & 5 & silt/clay & $.31-1.75$ & $16-47$ & $.010-.037$ & .021 & .013 \\
\hline
\end{tabular}

and two cross sections surveyed in 1994 indicate a decrease in cross-sectional area in the range from 17.1 to 39.1 percent below the design high-water elevation depending on the location of the 1994 cross section. Because the initial cross section surveyed in 1994 included a high-flow channel that runs perpendicular to the river under the southeast side of the bridge opening, a second cross section of the south bank of the bridge opening about $12 \mathrm{ft}$ downstream of the bridge also was surveyed in 1994. The initial cross section surveyed in 1994 at the downstream side of the bridge is shown as a jagged, solid line in figure 15A. The second cross section surveyed in 1994 about $12 \mathrm{ft}$ downstream of the bridge is shown as a long-dashed and dotted line in figure $15 \mathrm{~A}$. The line representing the second cross section surveyed in 1994 of the south bank was connected to the line representing the channel bed and north bank portion of the initial cross section surveyed in 1994; this composite cross section might provide the most accurate representation of aggradation at the bridge opening. Figure 15A shows that for the period 1956-94, deposition occurred on both the left and right banks of the bridge opening, and scour occurred across the channel bed. Bridge crosssection and geometry elevations obtained from the bridge-situation plan were adjusted by $-40.85 \mathrm{ft}$ to rectify them with bridge elevations surveyed during 1994.

Differences in elevation between the 1956 cross section and a cross section obtained from a discharge measurement made in 1991 (fig. 15A) indicate a decrease in cross-sectional area of 49.8 percent. Differences in elevation between the 1991 and 1994 cross sections indicate that the 1993 flood scoured the channel bed from between about 3 to $10 \mathrm{ft}$, thus increasing the cross-sectional area measured for 1994 from the cross-sectional area that was measured for 1991. The peak discharge on July 19, 1993, for the Iowa River at Marengo was $38,000 \mathrm{ft}^{3} / \mathrm{s}$ and the recurrence interval for this flood is approximately 90 years. Aggradation appears to have been occurring even when the bridge was built in 1956, as differences in elevation between the proposed 1956 bridge-opening cross-section excavation and a cross section obtained from a discharge measurement made in 1959 indicate a decrease in cross-sectional area of 15.0 percent and an average aggradation rate of $0.390 \mathrm{ft} / \mathrm{yr}$. An increase in elevation along portions of the overbank between the 1991 cross section and the 1994 composite cross section (includes survey of right bank $12 \mathrm{ft}$ downstream of bridge) indicates that the overbank part of the bridge opening continued to aggrade, raising the elevation of the overbank near station 500 to almost the design high-water elevation (fig. 15A).

The stage-discharge relation of five selected rating curves (fig. 15B) shows a general trend of decreasing gage heights for specific low-flow discharges and a general trend of increasing gage heights for specific high-flow discharges. A time series of the 27 rating curves developed for the period of record (fig. 15C) also shows these general trends. It is not known if the effect of Coralville Dam, located approximately 56 river-miles downstream from the County V66 bridge, is contributing to aggradation on the Iowa River at Marengo. Generally, the change in slope of a river by construction of a reservoir will cause deposition not only in the reservoir, but might cause aggradation problems in the channel for a considerable distance upstream as the river adjusts to its new conditions (Upper Mississippi River Comprehensive Basin Study Coordinating Committee, 1970, p. G-10). However, hydraulic analyses would be required to determine the 

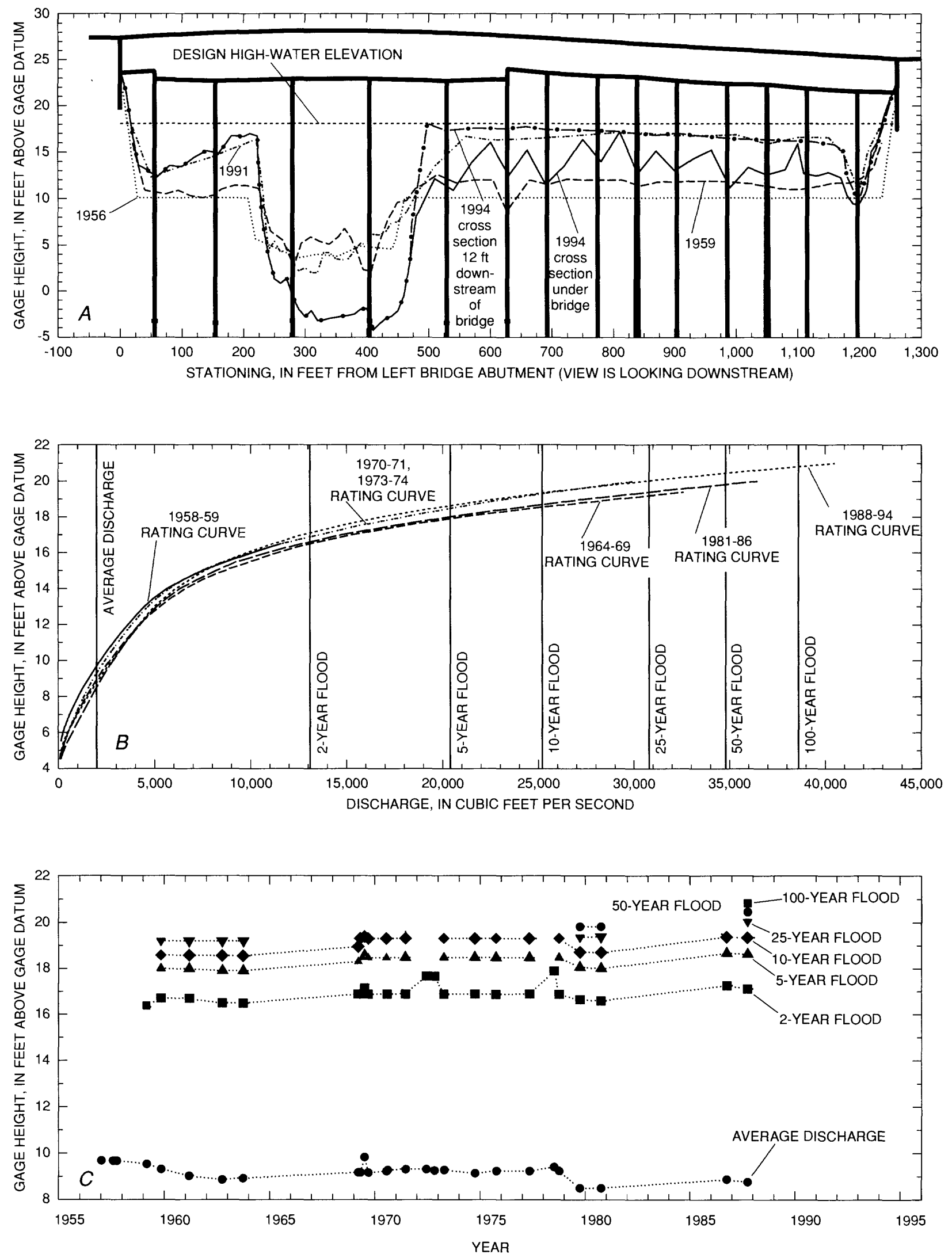

Figure 15. Selected (A) bridge-opening cross sections, (B) stage-discharge rating curves, and (C) time series of rating-curve stages for selected discharges for County Road V66 bridge crossing the lowa River at Marengo, bridge site number 10 (streamflow-gaging station number 05453100). 
extent to which the Coralville Lake is significantly affecting the hydraulic properties and sediment-transport capacity of the Iowa River at Marengo.

\section{U.S. Highway 63 Bridge Crossing the South Skunk River near Oskaloosa (Site 11)}

The U.S. Highway 63 bridge crosses the South Skunk River about 4 mi north of Oskaloosa in Mahaska County. This is the site of the South Skunk River near Oskaloosa streamflow-gaging station (station number 05471500; fig. 1, site 11). Streamflow records for the period October 1945 to September 1993 were available for use in this study. The datum of the gage is $685.50 \mathrm{ft}$ above sea level.

The U.S. Highway 63 bridge (fig. 16A) was built in 1979. The design high-water elevation for the bridge was $709.80 \mathrm{ft}$ (gage height $24.30 \mathrm{ft}$ ). Differences in elevation between bridge-opening cross-sections obtained from the IDOT bridge-situation plan and from the 1994 transit survey indicate a decrease in cross-sectional area of 8.5 percent below the design high-water elevation. Figure 16A shows that for the period 1979-94, deposition occurred on both the left and right banks of the bridge opening, and scour occurred on the far left and right sides of the channel bed. Bridge cross-section and geometry elevations obtained from the bridge-situation plan were adjusted by $-7.00 \mathrm{ft}$ to rectify them with bridge elevations surveyed during 1994. The stage-discharge relation of four selected rating curves (fig. 16B) shows a general trend of increasing gage height for specific discharges, and a time series of the 17 rating curves developed for the period of record (fig. 16C) also shows this general trend.

\section{State Highway 149 Bridge Crossing the North Skunk River near Sigourney (Site 12)}

The State Highway 149 bridge crosses the North Skunk River about 2.2 mi south of Sigourney in Keokuk County. This is the site of the North Skunk River near Sigourney streamflow-gaging station (station number 05472500; fig. 1, site 12). Streamflow records for the period October 1945 to September 1993 were available for use in this study. The datum of the gage is $651.53 \mathrm{ft}$ above sea level.

The State Highway 149 bridge (fig. 17A) was built in 1987. The design high-water elevation for the bridge was $675.5 \mathrm{ft}$ (gage height $24.0 \mathrm{ft}$ ). Differences in elevation between bridge-opening cross-sections obtained from the IDOT bridge-situation plan and from a 1993 discharge measurement indicate a decrease in cross-sectional area of 11.9 percent below the design high-water elevation. Figure 17A shows that for the period 1987-93, deposition occurred across the bridge opening. The stage-discharge relation of four selected rating curves (fig. 17B) shows a general trend of increasing gage height for most of the specific discharges, and a time series of the 18 rating curves developed for the period of record (fig. 17C) also shows this general trend.

Dendrogeomorphic analyses, bridge site 11

\begin{tabular}{lcccccccc}
\hline & & & \multicolumn{2}{c}{ Range of } & & \multicolumn{2}{c}{$\begin{array}{c}\text { Aggradation rates } \\
\text { (feet per year) }\end{array}$} \\
$\begin{array}{c}\text { Location } \\
\text { relative } \\
\text { to bridge }\end{array}$ & $\begin{array}{c}\text { Number } \\
\text { of } \\
\text { samples }\end{array}$ & $\begin{array}{c}\text { Dominant } \\
\text { sediment } \\
\text { type } \\
\text { sampled }\end{array}$ & $\begin{array}{c}\text { Deposition } \\
\text { depths } \\
(\mathrm{ft})\end{array}$ & $\begin{array}{c}\text { Tree } \\
\text { ages } \\
\text { (years) }\end{array}$ & Range & Mean & Median \\
\hline Left upstream & 5 & silt/clay & $0.83-3.01$ & $23-64$ & $0.036-.087$ & 0.053 & 0.047 \\
Right upstream & 5 & silt/clay & $1.46-3.08$ & $27-73$ & $.032-.099$ & .064 & .059 \\
Left downstream & 5 & sand & $.37-2.97$ & $17-55$ & $.010-.087$ & .043 & .043 \\
Right downstream & 5 & silt/clay & $1.02-1.83$ & $26-50$ & $.028-.052$ & .043 & .045 \\
\hline
\end{tabular}



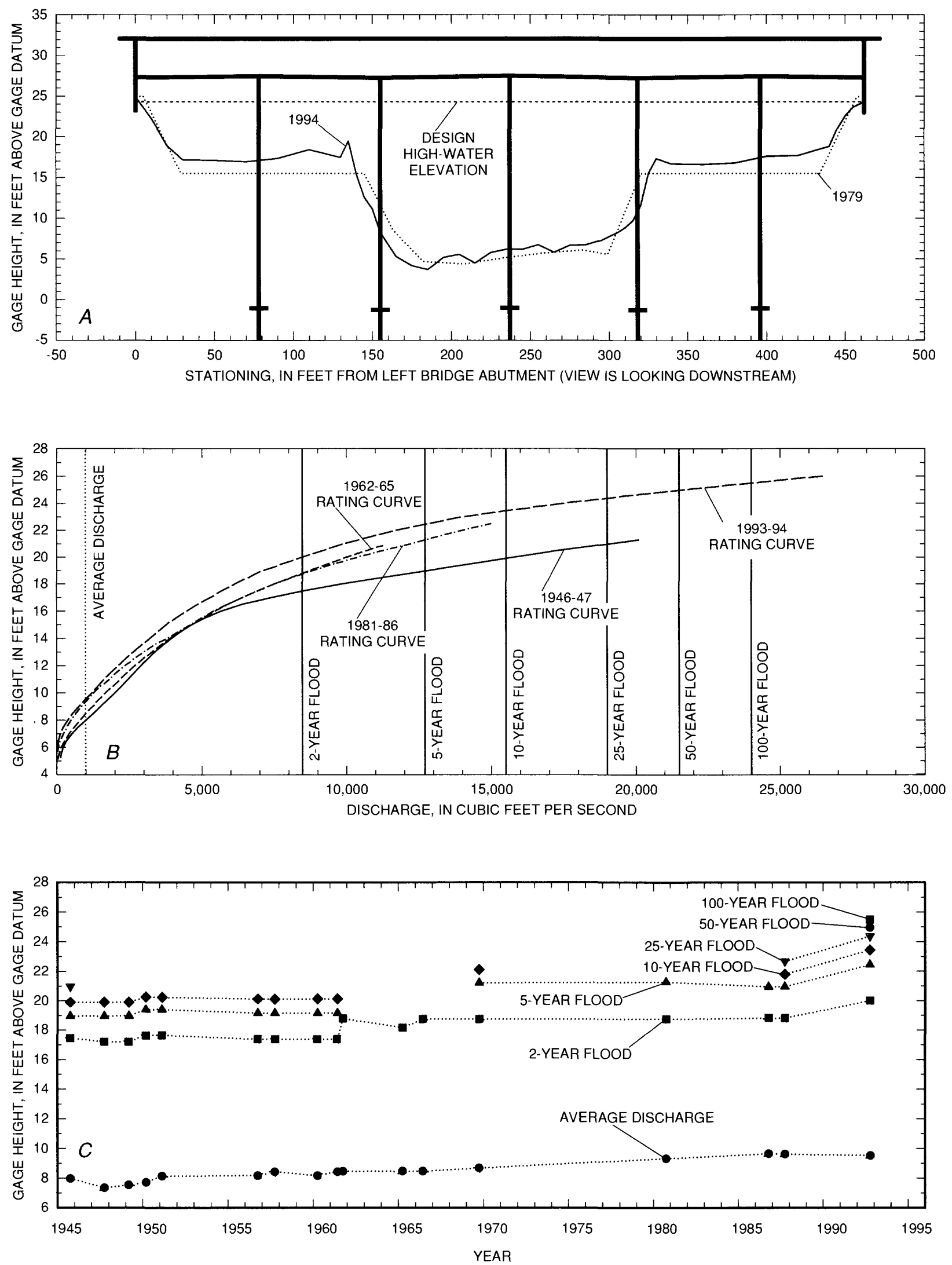

Figure 16. Selected (A) bridge-opening cross sections, (B) stage-discharge rating curves, and (C) time series of rating-curve stages for selected discharges for U.S. Highway 63 bridge crossing the South Skunk River near Oskaloosa, bridge site number 11 (streamflow-gaging station number 05471500). 

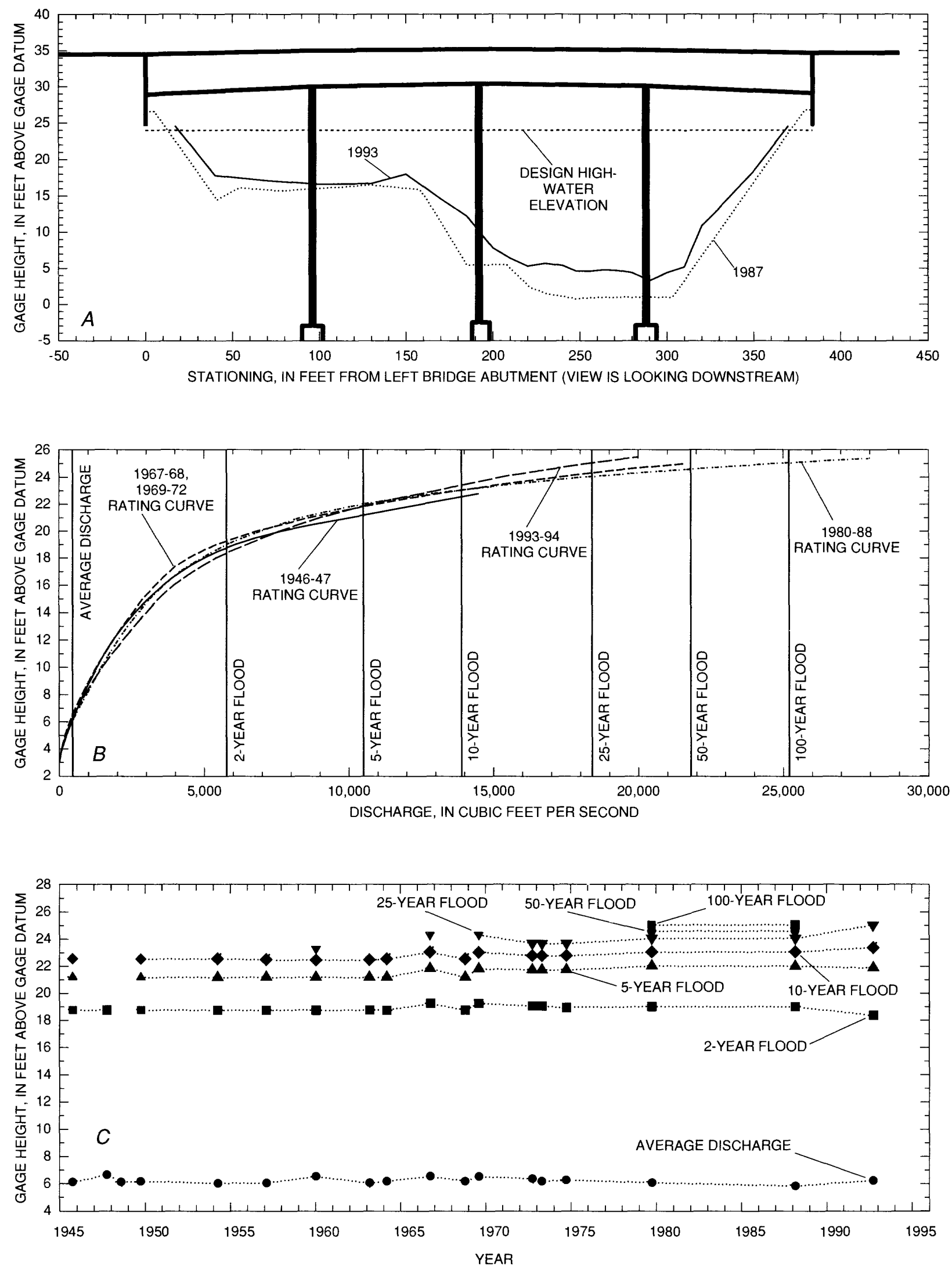

Figure 17. Selected (A) bridge-opening cross sections, (B) stage-discharge rating curves, and (C) time series of rating-curve stages for selected discharges for State Highway 149 bridge crossing the North Skunk River near Sigourney, bridge site number 12 (streamflow-gaging station number 05472500). 
Dendrogeomorphic analyses, bridge site 12

\begin{tabular}{|c|c|c|c|c|c|c|c|}
\hline \multirow[b]{2}{*}{$\begin{array}{l}\text { Location } \\
\text { relative } \\
\text { to bridge }\end{array}$} & \multirow[b]{2}{*}{$\begin{array}{c}\text { Number } \\
\text { of } \\
\text { samples }\end{array}$} & \multirow{2}{*}{$\begin{array}{c}\text { Dominant } \\
\text { sediment } \\
\text { type } \\
\text { sampled }\end{array}$} & \multicolumn{2}{|c|}{ Range of } & \multicolumn{3}{|c|}{$\begin{array}{l}\text { Aggradation rates } \\
\text { (feet per year) }\end{array}$} \\
\hline & & & $\begin{array}{l}\text { Deposition } \\
\text { depths } \\
\text { (ft) }\end{array}$ & $\begin{array}{c}\text { Tree } \\
\text { ages } \\
\text { (years) }\end{array}$ & Range & Mean & Median \\
\hline Left upstream & 5 & silt/clay & $0.10-.72$ & $25-49$ & $0.004-.015$ & 0.011 & 0.010 \\
\hline Right upstream & 5 & silt/clay & $.16-1.24$ & $18-40$ & $.008-.037$ & .023 & .029 \\
\hline Left downstream & 5 & sand & $1.02-1.50$ & $25-37$ & $.028-.058$ & .043 & .040 \\
\hline Right downstream & 5 & silt/clay & $.29-.75$ & $17-40$ & $.012-.044$ & .021 & .016 \\
\hline
\end{tabular}

\section{COMPARISON AND DISCUSSION OF AGGRADATION MEASUREMENTS}

Results of the aggradation measurements (table 1) indicate that aggradation is occurring in both the Iowa and Skunk River Basins. In general, slightly higher aggradation rates were estimated for the Iowa River for the reach from State Highway 330 near Albion downstream to County Road V66 at Marengo (sites 5-10). Estimates of mean flood-plain aggradation rates calculated using the dendrogeomorphic method at the 12 bridge sites ranged from 0.013 to $0.051 \mathrm{ft} / \mathrm{yr}$, and estimates of median rates ranged from 0.010 to $0.046 \mathrm{ft} / \mathrm{yr}$. Trees sampled for the dendrogeomorphic analyses ranged in age from 9 to 98 years. Estimates of average bridge-opening aggradation rates calculated using the bridge-opening cross-section method at the 12 bridge sites ranged from -0.977 to $0.500 \mathrm{ft} / \mathrm{yr}$. Measurement periods used in the bridgeopening cross-section analyses ranged in length from 3 to 51 years. The stage-discharge rating-curve method used the 5-year flood discharge to estimate floodway aggradation rates and the average discharge to estimate channel-aggradation rates at six of the bridge sites. Estimates calculated using the stage-discharge rating-curve method ranged from -0.028 to $0.298 \mathrm{ft} / \mathrm{yr}$ for floodway aggradation, and from -0.031 to $0.108 \mathrm{ft} / \mathrm{yr}$ for channel aggradation. Measurement periods used in the stage-discharge rating-curve analyses ranged in length from 5 to 75 years. Sediments deposited during the 1993 flood on the nine sediment pads were variable and depths of deposition ranged from 0.004 to $2.95 \mathrm{ft}$. Average flood-plain aggradation rates estimated from sediment-pad measurements at three of the bridge sites on the Iowa River in the vicin- ity of Marshalltown ranged from 0.037 to $1.100 \mathrm{ft} / \mathrm{yr}$ for 1993 , and ranged from 0.038 to $0.579 \mathrm{ft} / \mathrm{yr}$ for 1993-94.

A direct comparison cannot be made between aggradation rates calculated using each of the four measurement methods because of differences in time periods and aggradational processes that were measured by each method. Measurement periods used to estimate average aggradation rates ranged in length from 1 to 98 years and varied among methods and sites. The methods measured different aggradational processes; the dendrogeomorphic and sediment-pad methods measured flood-plain aggradation, the crosssection method measured aggradation at bridge openings, and the rating-curve method measured both floodway and channel aggradation.

Aggradation rates calculated using the bridgeopening cross-section method were much more variable than the rates calculated using the dendrogeomorphic and rating-curve methods. Because cross sections were surveyed for bridge openings following the 1993 flood, cross-sectional areas at some of the bridge openings might have been affected by scour or deposition as a result of that flood. Aggradation rates calculated using the dendrogeomorphic method might also have been affected by the 1993 flood, as sedimentdeposition depths were measured following the flood. Aggradation rates calculated using the stage-discharge rating-curve method were not affected by the 1993 flood, as all of the rating curves used in the analyses were in effect before the flood. Rates calculated using the rating-curve method might not represent changes in stage due only to deposition or scour, as other changes in channel and flood-plain conditions also can affect a stage-discharge relation. 
The highest aggradation rates calculated for the Iowa River Basin using the dendrogeomorphic and rating-curve measurement methods were for the State Highway 14 crossing at Marshalltown (table 1, site 6), where these highest rates were 0.045 and $0.124 \mathrm{ft} / \mathrm{yr}$, respectively. The highest aggradation rates calculated for the Skunk River Basin were for the U.S. Highway 63 crossing the South Skunk River near Oskaloosa (table 1, site 11), where these highest rates were 0.051 and $0.298 \mathrm{ft} / \mathrm{yr}$, respectively. The similar aggradation rates calculated for both the Marshalltown and Oskaloosa bridge sites using each measurement method, the dendrogeomorphic method and the rating-curve method for the 5-year flood discharge, indicate that similar flood-plain and floodway aggradation processes might be occurring at the two sites.

Information on recent aggradation rates (table 1) was available from stage-discharge rating curves at 5 of the bridge sites (sites 1, 6,10,11, and 12), from bridge-opening cross sections obtained from discharge measurements at 2 of the bridge sites (sites 6 and 10), and from sediment-pad measurements at 3 of the bridge sites (sites 5-7). A comparison of rating-curve aggradation rates calculated using the 5-year flood discharge indicates that recent floodway-aggradation rates might be greater than those calculated for longer measurement periods at Marshalltown, Marengo, and Oskaloosa (sites 6, 10, and 11). A similar comparison made using the average discharge indicates that recent channel-aggradation rates might be greater at Marshalltown, Marengo, and Sigourney (sites 6, 10, and 12). A comparison of bridge-opening cross sections for the State Highway 14 bridge at Marshalltown indicates that recent bridge-opening aggradation rates also might be greater. Information obtained from sedimentpad measurements of sediments deposited during the 1993 flood indicates that aggradation along the Iowa River in the vicinity of Marshalltown is quite variable and site specific. At some flood-plain locations, sediment deposition during the 1993 flood was substantial in both depth and lateral extent of deposits.

Although information on recent aggradation rates is not considered to be as reliable as information on aggradation rates calculated for longer measurement periods, information on recent aggradation rates is indicative of current aggradational processes and useful to planners and engineers. Information on recent aggradation rates is not considered to be as reliable because: differences in stages between recent rating curves could include nonrepresentative short-term fluctuations in the stage-discharge relation; differences in elevations between cross sections obtained from high-water discharge measurements and low-water transit surveys could include discharge-related scour and deposition fluctuations in channel bed and overbank elevations; and sediment-pad measurements provide only a small sample of sediment-deposition depths and they might not be representative of overall flood-plain deposition.

Aggradation rates calculated for both the upstream and downstream corners of bridges at the 12 bridge sites using the dendrogeomorphic method, indicate that upstream mean and median rates of floodplain aggradation are not greater than downstream mean and median rates at 9 of the 12 bridge sites (sites $1-4,6-9$, and 12). This suggests that backwater effects from bridge structures and causeways at these sites have not contributed to increased aggradation on the upstream sides of these bridges. The dendrogeomorphic analyses do indicate that greater aggradation rates might be occurring on the upstream sides of the State Highway 330 bridge near Albion (site 5), the County Road V66 bridge at Marengo (site 10), and the U.S. Highway bridge near Oskaloosa (site 11). Hydraulic analyses would be required to determine whether any of these bridge structures and causeways significantly affect the hydraulic properties and sediment-transport capacity of the river at these sites.

Table 2 lists average aggradation rates calculated for studies conducted in other states. These studies estimated aggradation rates for both natural and channelized streams using one of three measurement methods. In general, these studies indicated aggradation rates for natural streams ranged from 0.016 to $0.492 \mathrm{ft} / \mathrm{yr}$, and aggradation rates for channelized streams ranged from 0 to $0.492 \mathrm{ft} / \mathrm{yr}$. Because the aggradation rates estimated in these studies represent a variety of climatic, physiographic, and hydrologic conditions, they might not be comparable to conditions in the Iowa and Skunk River Basins. Table 2 is presented as a frame of reference of aggradational processes occurring in other states, so as to exemplify how usual, or unusual, the aggradational processes occurring in the Iowa and Skunk River Basins might be. Flood-plain aggradation rates calculated in this study using dendrogeomorphic analyses (table 1) are within the range of rates listed in table 2 for dendrogeomorphic analyses conducted in other states. 
Table 2. Summary of aggradation rates calculated for studies conducted in other states

\begin{tabular}{|c|c|c|c|}
\hline Aggradation-measurement reference and remarks & Type of stream & $\begin{array}{l}\text { Measurement } \\
\text { method }\end{array}$ & $\begin{array}{l}\text { Average } \\
\text { aggradation rate } \\
\text { (feet per year) }\end{array}$ \\
\hline $\begin{array}{l}\text { Trimble and Lund (1982, p. 18) } \\
\text { Depositional periods since } 1853 \text { for Coon Creek, southwestern Wisconsin }\end{array}$ & Natural & $\begin{array}{l}\text { Volumetric } \\
\text { surveys }\end{array}$ & $0.049-0.492$ \\
\hline $\begin{array}{l}\text { Johnston and others (1984, p. 289) } \\
\text { Natural levee deposition rate for a small stream, northeastern Wisconsin; } \\
\text { estimate not determined for deposition rates over broad extent of wetland }\end{array}$ & Natural & $\begin{array}{c}{ }^{137} \mathrm{Cs} \text { dating } \\
\text { techniques }\end{array}$ & 0.086 \\
\hline $\begin{array}{l}\text { Hupp and Morris (1990) } \\
\text { Forested wetland on flood plain adjacent to Cache River, Arkansas; } \\
\text { rates for elevated portions of the flood plain and slough, respectively }\end{array}$ & $\begin{array}{l}\text { Channelized } \\
\text { upstream }\end{array}$ & $\begin{array}{l}\text { Dendrogeomorphic } \\
\text { analyses }\end{array}$ & $0.0003,0.020$ \\
\hline $\begin{array}{l}\text { Simon and Hupp (1992, p. 95-96) } \\
\text { Hatchie River, western Tennessee }\end{array}$ & Natural & $\begin{array}{l}\text { Dendrogeomorphic } \\
\text { analyses }\end{array}$ & $0.016-0.049$ \\
\hline $\begin{array}{l}\text { Simon and Hupp (1992, p. 95-96) } \\
\text { Western Tennessee streams }\end{array}$ & Channelized & $\begin{array}{l}\text { Dendrogeomorphic } \\
\text { analyses }\end{array}$ & $0.0-0.492$ \\
\hline $\begin{array}{l}\text { Wolfe and Diehl (1993, p. 9) } \\
\text { North Fork Forked Deer River, western Tennessee }\end{array}$ & Channelized & $\begin{array}{l}\text { Dendrogeomorphic } \\
\text { analyses }\end{array}$ & $0.0-0.24$ \\
\hline $\begin{array}{l}\text { Phipps and others }(1995, \text { p. } 23) \\
\text { Kankakee River, eastern Illinois; } \\
\text { pre-1950 and post-1950 rates, respectively }\end{array}$ & $\begin{array}{l}\text { Channelized } \\
\text { upstream }\end{array}$ & $\begin{array}{l}\text { Dendrogeomorphic } \\
\text { analyses }\end{array}$ & $\begin{array}{l}0.011-0.026 \\
0.018-0.031\end{array}$ \\
\hline
\end{tabular}

\section{POSSIBLE FACTORS CONTRIBUTING TO AGGRADATION OF THE IOWA RIVER NEAR MARSHALLTOWN}

Several interrelated factors might be contributing to the relatively high rate of aggradation of the Iowa River at Marshalltown. Information presented in this section of the report identifies, qualitatively, factors that might contribute to the aggradation. Figure 18 shows an aerial photograph taken March 22, 1994, of the Iowa River along the northwest side of Marshalltown (photograph supplied by Leon Lamer, General Manager, Marshalltown Water Works). The Iowa River flows eastward (left to right) in the photograph. Several locations can be seen on the north side of the river where sediments were deposited during the 1993 flood. The area northwest of the Iowa Soldiers Home represents approximately 20 to 30 acres of flood plain where 1 to $12 \mathrm{in}$. of sand were deposited (Richard Kemler, landowner, oral commun., November 1994).

\section{Erosion and Sedimentation}

The physiography of the Iowa River Basin changes between Alden and Eldora as the Iowa River crosses from the Des Moines Lobe landform region to the Southern Iowa Drift Plain landform region (fig. 1). Mainly due to the steeper topography, erosion is greater from watersheds in the Southern Iowa Drift Plain than from watersheds in the Des Moines Lobe. A map shown in the Upper Mississippi River Basin Commission report $(1979$, p. 85$)$ indicates that soil erosion potential is very severe in southern Marshall County, severe in the northeastern portion of the county, and moderate in the northwestern portion of the county.

\section{Loess Soils}

The Southern Iowa Drift Plain landscape in the vicinity of Marshall County (fig. 1) consists primarily of glacial till covered by a mantle of wind-deposited loess (Iowa Natural Resources Council, 1955a, p. 7; Oschwald and others, 1965, p. 66). Loess consists almost entirely of silt but might include small amounts of very fine sand or clay (Oschwald and others, 1965, p. 6). The loess deposits in the Iowa River Basin are different from the loess deposits in western lowa in that the deposits are not as thick, and they are comprised of finer particles and have much lower infiltration rates (Iowa Natural Resources Council, 1955a, p. 3 and 7). The loess is thickest near the major streams, where it might extend to depths of 30 to $40 \mathrm{ft}$. On the 


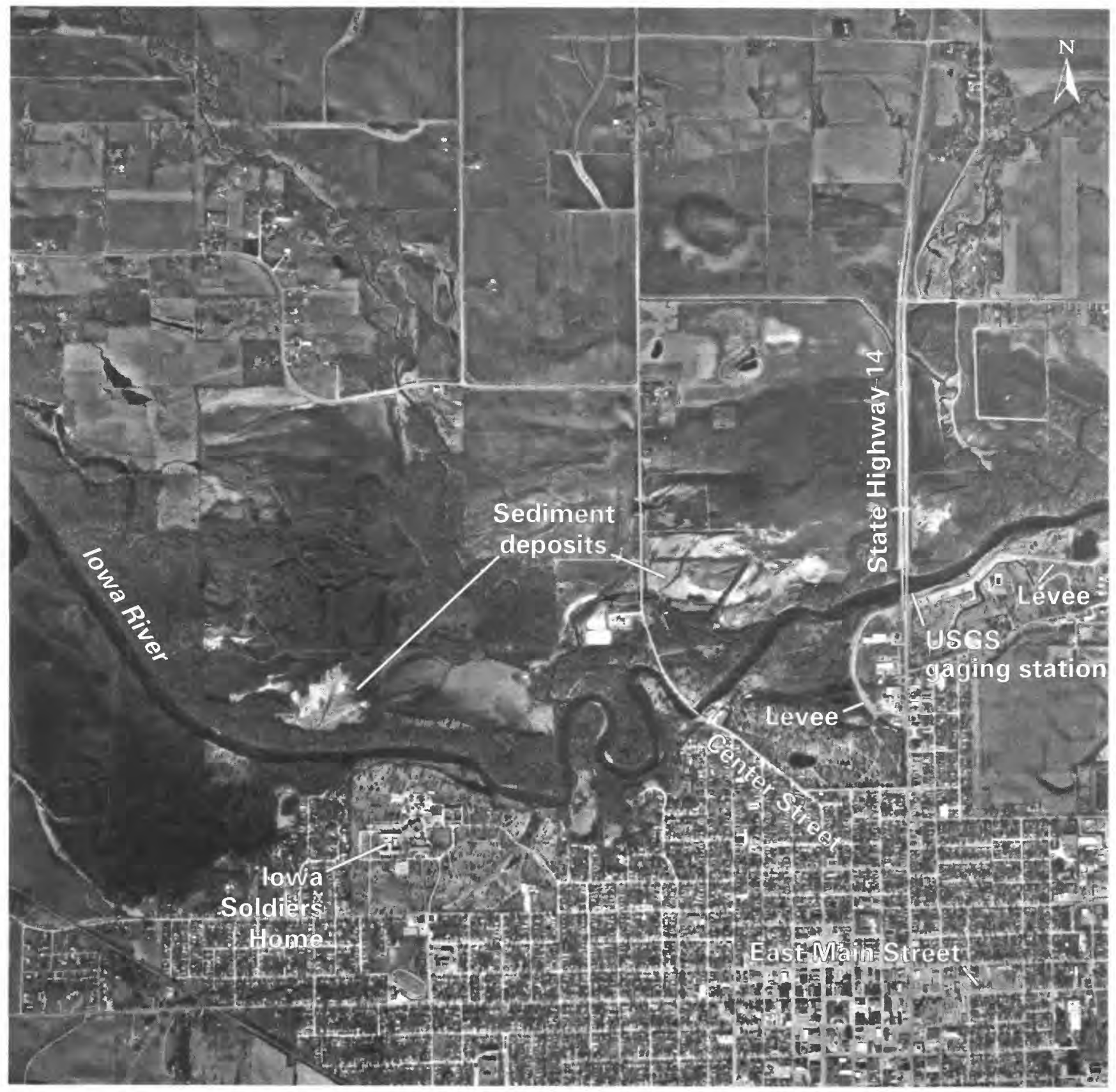

Figure 18. Sediment deposits from the 1993 flood along the flood plain of the lowa River at Marshalltown, lowa (Photograph on March 24, 1994, by Aerial Services Inc., Cedar Falls, lowa). 
divides, loess deposits are seldom more than $10 \mathrm{ft}$ thick. In Grundy, Hardin, and northern Marshall Counties, the loess is predominantly 5 to $10 \mathrm{ft}$ thick; in southern Marshall County the loess is about 17 to $25 \mathrm{ft}$ thick on the uplands and is thinner on the side slopes (Oschwald and others, 1965, p. 66). Loess is highly erodible and unstable when wet. Deep, narrow gullies, which can lengthen and widen quickly after rainstorms, are characteristic erosional features of loess soils (Prior, 1991, p. 49, 56-57). When rising waters saturate the base of channel banks, the loess can no longer bear the weight of overlying material and it collapses easily, resulting in bank sloughing. Channel erosion from areas in and around Marshall County with thick deposits of loess soils might contribute large sediment loads to the Iowa River.

\section{Land Use in Marshall County}

The following information about land use in Marshall County was supplied by the U.S. Department of Agriculture, Natural Resources Conservation Service, Marshall County Field Office (Dana Holland, oral commun., February 1995, and written commun., March 1995). Soils in Marshall County can generally be described as highly productive and well drained. Over 90 percent of the soils in Marshall County were formed from loess and have a silty-clay-loam texture. Tributary flow to the Iowa River in Marshall County upstream of Marshalltown is from watersheds that generally are flashy and are intensively farmed for crop production. These drainage basins have steep slopes ranging from 5 to 14 percent and have the potential to contribute large sediment yields to the Iowa River. About 83 percent of the total acreage in Marshall County is cropland and soil erosion is a primary concern for nearly 70 percent of this cropland. About 10 percent of the cropland has been enrolled in the Conservation Reserve Program (CRP) defined by the 1985 Farm Bill (U.S. Congress, 1985). Nearly all of the CRP acreage is considered to be highly erodible soil. If the CRP contracts expire, it is estimated that 95 percent of the current CRP acreage would return to crop production. Nearly 40 percent of the cropland in Marshall County is presently farmed with no-till techniques. Annual soil-erosion losses in Marshall County have decreased from 7.0 to 5.9 tons per acre during the period 1982-92, but soil erosion in Marshall County still exceeds average statewide soil-erosion losses for 1992 of 4.0 tons per acre per year (Laurel Mulvey, U.S. Department of Agriculture, Natural Resources
Conservation Service, State of Iowa Office, written commun., February 1995).

\section{Suspended Sediment}

As sediment is transported through a stream system, the material either is entrained as suspended load or moves along the channel bottom as bed load (U.S. Army Corps of Engineers, 1981, p. 17). Most sediment is transported during periods of storm runoff (Upper Mississippi River Comprehensive Basin Study Coordinating Committee, 1970, p. G-9). Annual observed suspended-sediment yields in the headwaters of the Iowa River Basin (upstream of Iowa Falls) are relatively low, being less than 100 tons per square mile (U.S. Army Corps of Engineers, 1981, p. C43). Suspended-sediment yields are considerably higher in the Iowa River Basin downstream of Iowa Falls, where yields from one $10-\mathrm{mi}^{2}$ drainage area were approximately 1,100 tons per square mile per year and yields from one $100-\mathrm{mi}^{2}$ drainage area were about 650 tons per square mile per year (Upper Mississippi River Comprehensive Basin Study Coordinating Committee, 1970, p. G-42 to G-43, and G-95). Studies by Lane (1938) indicated that the suspended-sediment load in the Iowa River near Rowan (fig. 1, site 1) was about equally divided between silt and clay with only a small percentage of sand; whereas, in the Iowa River at Marengo (fig. 1, site 10) the load composition was 79 percent silt, 15 percent clay, and 6 percent sand.

Sediment-yield estimates computed from suspended-sediment data and adjusted for a base period of 1945-64 were 34 tons per square mile per year for the Iowa River near Rowan (site 1), 330 tons per square mile per year for the Iowa River at Marshalltown (site 6), and 365 tons per square mile per year for the Iowa River at Marengo (site 10) (Upper Mississippi River Comprehensive Basin Study Coordinating Committee, 1970, p. G-23). This pattern of increasing sediment yields at downstream locations on the Iowa River is opposite the sediment-yield pattern indicated by the majority of the suspended-sediment data analyzed for the Upper Mississippi River Basin. Typically, as the size of the drainage area increases, the rate of sediment production per square mile decreases (Upper Mississippi River Comprehensive Basin Study Coordinating Committee, 1970, p. G-27). These estimates indicate that suspended-sediment yields to the Iowa River greatly increase between Rowan and Marshalltown, and become greater between Marshalltown and Marengo. 
A sediment-measurement station was operated by the USGS on the Iowa River at Marshalltown (sediment-station number 05451500; fig. 1, site 6) from April 1988 to February 1995; sediment data collected through September 1994 were used for this study. Annual suspended-sediment yields for the Iowa River at Marshalltown for this period ranged from 5 tons per square mile during water year 1989 (a drought year, ending September 30,1989) to 1,759 tons per square mile during water year 1993 (a flood year, ending September 30, 1993) (U.S. Geological Survey, 1990-95). The average suspended-sediment yield at this station for water years 1989-94 was 572 tons per square mile per year, which is almost twice the amount estimated the period 1945-64.

\section{Increase in Streamflow}

Suspended-sediment yield differences between the two time periods noted above are probably due to differences in streamflow between these time periods, as the mean daily discharge of the Iowa River at Marshalltown for the period 1989-94 $\left(1,440 \mathrm{ft}^{3} / \mathrm{s}\right)$ was about twice the mean daily discharge for the period $1945-64\left(705 \mathrm{ft}^{3} / \mathrm{s}\right)$. Changes in streamflow can cause changes in aggradation rates. An increase in streamflow typically will cause an increase in sediment trans- port in a stream (Phipps and others, 1995, p. 23). Figure 19 shows mean annual discharge for the Iowa River at Marshalltown for the period of record through water year 1994 (ending September 30, 1994). The figure indicates a trend increasing of streamflow. It is assumed that if a flood plain is inundated more frequently, as might occur with an increase in streamflow, more sediment will be deposited and greater aggradation rates will result. Many factors can affect streamflow, including changes in the quantity, duration, and intensity of rainfall; changes in land-use practices; and changes in channel geometry (for example, straightening or dredging of a channel and draining of a wetland) (Phipps and others, 1995, p. 23).

\section{Channelization}

A drainage district was established in 1920 for the purpose of straightening the Iowa River to provide flood protection for farm lands along the river bottom. The channel of the Iowa River in Marshall County was straightened from the Marshall-Hardin County line to the Iowa Soldiers Home in Marshalltown (figs. 1 and 18) during the early 1920 's. At the time, this work was considered to have been beneficial in the prevention of flooding of the bottom lands along this reach of the

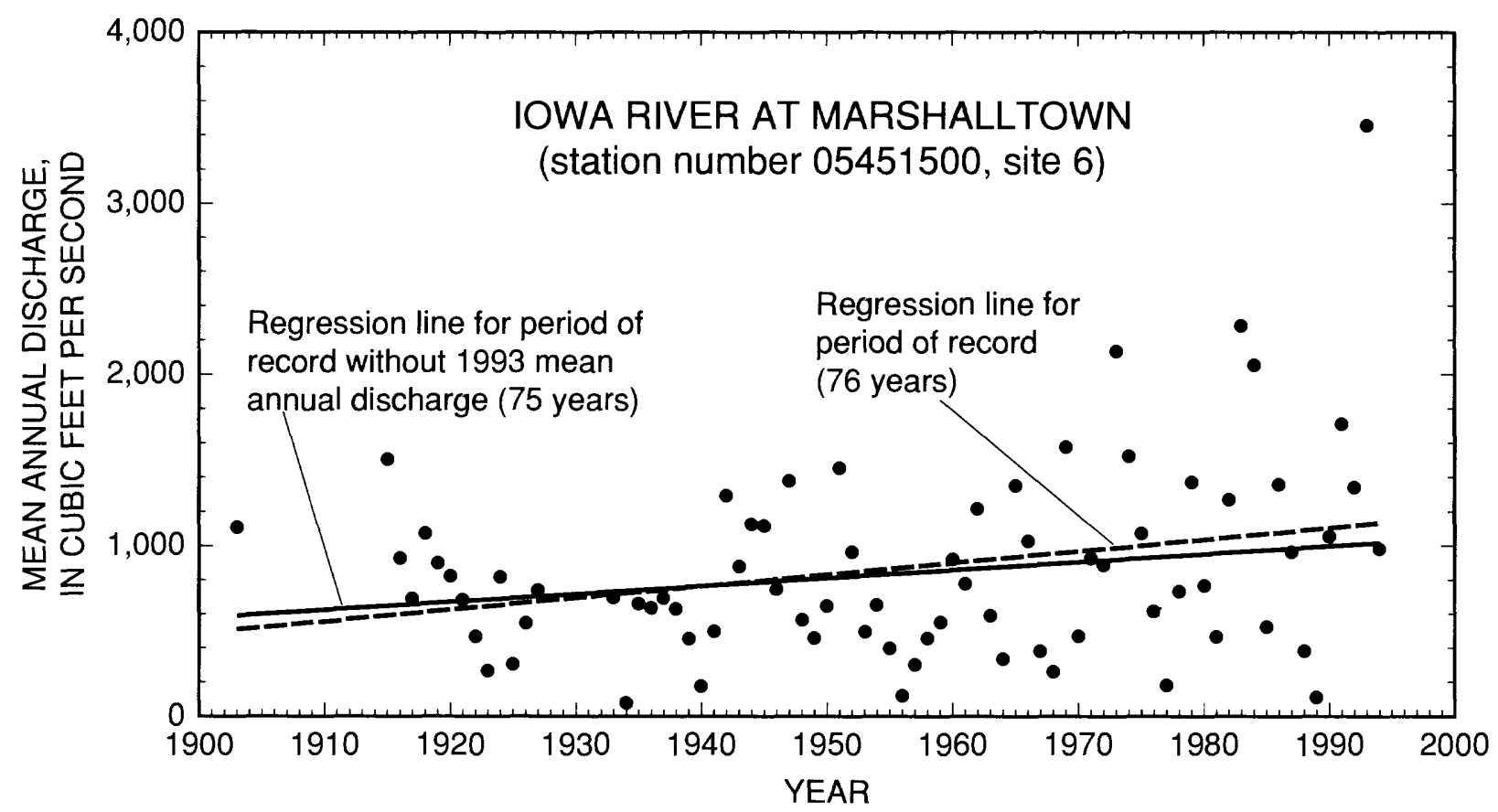

Figure 19. Mean annual discharge for the lowa River at Marshalltown, lowa, streamflow-gaging station for the period of record through 1994. 
river (U.S. Army Chief of Engineers, 1930, p. 44). Opposition to the channel straightening brought the work to an end about 1922 (Blanchard, 1955; Marshalltown Times-Republican, February 15, 1991; articles provided by Garry Brandenburg, Director, Marshall County Conservation Board, written commun., March 1993).

Pre- and post-channelization measurements of channel length and channel-bed gradient of the Iowa River were made from a channelization plan prepared by F.B. Ingersoll, dated June 1, 1919 (plan provided by Ed Kasper, Marshall County Engineer, November 1994). The pre-channelized length of the Iowa River between the county line and the Iowa Soldiers Home was about $21.4 \mathrm{mi}$ and the gradient was about $1.85 \mathrm{ft}$ / $\mathrm{mi}$. The post-channelized length was about $14.1 \mathrm{mi}$ and the gradient was about $2.81 \mathrm{ft} / \mathrm{mi}$. Channelization decreased the length of the river 34 percent $(7.3 \mathrm{mi})$ and increased the gradient 52 percent $(0.96 \mathrm{ft} / \mathrm{mi})$. From basic hydraulic principles, an increase in stream gradient produces an increase in flow velocity. The sediment-transport capacity of a stream is dependent on mean flow velocity and energy slope, among other factors; the transport capacity increases with increasing mean flow velocity and energy slope (Nakato, 1981, p. 5). The present (1994) gradient of the Iowa River upstream of Marshalltown between the County Road E1 8 and State Highway 14 bridges (sites 4 and 6) is about $2.59 \mathrm{ft} / \mathrm{mi}$, and downstream of Marshalltown it is about $1.73 \mathrm{ft} / \mathrm{mi}$ between the State Highway 14 and U.S. Highway 30 bridges (sites 6 and 7), as determined by the difference in average channel-bed elevations. This downstream decrease in stream gradient indicates a possible reduction in the sedimenttransport capacity of the Iowa River in the vicinity of Marshalltown.

The channelization plan noted that a typical cross section of the river channel would have a base width of $45-55 \mathrm{ft}$, a top width of about $67-81 \mathrm{ft}$, and a depth of 11-13 ft, and that levees would be constructed about $10 \mathrm{ft}$ back from the top of the channel on either bank to a height of about 13-16 ft from the material excavated during the channelization work. Measurements of bridge-opening cross sections surveyed during 1994 indicate that current channel base widths at County Road E18 (fig. 8) and State Highway 330 (fig. 9) are approximately 186 and 192 ft, respectively, and current channel top widths are approximately 270 and $318 \mathrm{ft}$, respectively. Both of these bridges are in the channelized reach and their bridgeopening widths indicate that significant channel wid- ening, on the order of about 275 to 300 percent, has occurred since the river was straightened.

Channelization might have increased channel erosion (channel degradation and widening) along the main stem of the Iowa River upstream of Marshalltown and along tributaries draining to the Iowa River. Studies conducted in western Tennessee (Simon, 1994; Wolfe and Diehl, 1993; Simon and Hupp, 1992), in Mississippi (Wilson and Turnipseed, 1994; Turnipseed and Wilson, 1992), and in eastern Illinois (Phipps and others, 1995) document the gradation processes and channel evolution resulting from channelization. Reports prepared for western Iowa document consequences of channelization in the Nishnabotna and Boyer River Basins (Iowa Natural Resources Council, 1955b, p. 3, 37, 41; Campbell and Johnson, 1970, p. 69). Channel widening and bank failure by mass-wasting processes are common occurrences following channelization in western Tennessee (Simon, 1994, p. 28 and 36), where channel erosion has resulted in an excess of sediment in the river and aggradation has occurred in reaches immediately downstream from the channelized reach.

Although it has been over 70 years since the Iowa River upstream of Marshalltown was channelized, consequences of this work have contributed to, and might still be contributing to, aggradation in the vicinity of Marshalltown. This channelized reach of the Iowa River has remained relatively straight and has retained the same approximate post-channelized length and gradient. Flow velocities and sedimenttransport capacity through this reach of the river have remained relatively efficient, and sediment loads greater than would occur had the river not been channelized might still be transported downstream to Marshalltown. At Marshalltown, where the Iowa River changes abruptly from a straightened reach to a meandering reach (fig. 18), flow velocities decrease as the channel gradient decreases, reducing the sedimenttransport capacity of the river and resulting in aggradation.

\section{Floodway Structures}

The construction of several floodway structures along the Iowa River might be affecting aggradation in the Marshalltown area. Hydraulic analyses would be required to determine whether any of these structures significantly affect the hydraulic properties and sediment-transport capacity of the river. 
Bridges cross the Iowa River in Marshalltown at Center Street, at State Highway 14, and at East Main Street. Prior to the late 1980 's, a railroad bridge also crossed the river about $0.2 \mathrm{mi}$ downstream of the East Main Street bridge. The Center Street and State Highway 14 bridges are shown in figure 18; the East Main Street bridge, located approximately five mi downstream of the State Highway 14 bridge, is not shown in figure 18. When the downstream bridge of State Highway 14 was constructed in 1968 , the northbound causeway built across the flood plain north of the bridge was constructed at an elevation about $3.7 \mathrm{ft}$ higher than the existing southbound causeway (Donald Schumann, IDOT, oral commun., November 1994). In 1987, when the upstream bridge of State Highway 14 was replaced, the southbound causeway across the flood plain north of the new bridge was raised to the same elevation as the northbound causeway. Since 1968, floods on the Iowa River have inundated both the northbound and southbound lanes of the State Highway 14 causeway north of the bridge 31 times, causing closure of the highway (Donald Schumann, IDOT, written commun., April 1995).

A low-head dam was constructed during 1934 about 0.4 mi downstream of the State Highway 14 bridge to act as a surface-water elevation control for the Marshalltown streamflow-gaging station (fig. 18). This dam was periodically washed-out during floods and rebuilt prior to 1968, when it was removed permanently. Notes from discharge measurements made at this site when this dam was in place refer to sand bars forming in the channel downstream of the bridge, and refer to the City of Marshalltown removing sand from the channel upstream of the dam. A low-head dam built in 1929 remains on the Iowa River just upstream of the Center Street bridge (Iowa Conservation Commission, 1979, p. 8-68).

A levee was constructed on the south bank of the river for a distance of about 0.7 mi downstream of the State Highway 14 bridge during the period 193739. Notes from discharge measurements made at the State Highway 14 site report that the levee was built to a gage height of about $14 \mathrm{ft}$. Additional levee construction occurred during the period $1960-62$ on the south bank of the river downstream of the bridge. A project to provide flood protection at Marshalltown was authorized in the 1965 Flood Control Act (U.S. Army Corps of Engineers, 1993, p. 39). The project consisted of levees, floodwalls, bridges, channel improvements, and interior drainage facilities on the
Iowa River and Linn Creek (not shown in fig. 18). Construction began in May 1972 and was completed in 1977. During this period the levee on the south bank of the river was improved and extended on either side of the State Highway 14 bridge, for a distance of about 2.2 mi downstream of the bridge to Linn Creek and about $0.4 \mathrm{mi}$ upstream of the bridge (fig. 18). It is not known what effect this levee has had on flow velocities and flood stages on the Iowa River. During large flood events such as occurred in 1993 on the Mississippi and Missouri Rivers, levees had minor overall effects on flood stage, but they might have had significant localized effects (Interagency Floodplain Management Review Committee, 1994, p. 50).

\section{AGGRADATION SIMILARITIES BETWEEN THE IOWA RIVER NEAR MARSHALL- TOWN AND THE SOUTH SKUNK RIVER NEAR OSKALOOSA}

Flood-plain and floodway-aggradation rates calculated for the State Highway 14 bridge crossing the Iowa River at Marshalltown are similar to those calculated for the U.S. Highway 63 bridge crossing the South Skunk River near Oskaloosa (table 1, rates calculated using the dendrogeomorphic method and using the stage-discharge rating-curve method for the 5-year flood discharge). Several conditions at these bridge sites appear to be similar and, as a result, similar aggradation processes might be occurring at the sites. The South Skunk River crosses from the Des Moines Lobe landform region to the Southern Iowa Drift Plain landform region at about the same distance upstream of Oskaloosa as the Iowa River crosses from the one landform region to the other upstream of Marshalltown (fig. 1). Agriculture is the predominant land use in both basins. Sediment yields from watersheds draining to the South Skunk River upstream of Oskaloosa apparently are comparable to sediment yields from watersheds draining to the Iowa River upstream of Marshalltown (Upper Mississippi River Comprehensive Basin Study Coordinating Committee, 1970, p. G-94 to G-95; Upper Mississippi River Basin Commission, 1979, p. 85-86). The South Skunk River upstream of Oskaloosa and the Iowa River upstream of Marshalltown have both been channelized.

The South Skunk River at Oskaloosa differs from the Iowa River at Marshalltown in that the South Skunk River does not abruptly change from a straight- 
ened channel to a meandering channel near Oskaloosa. There are fewer floodway structures (bridges and levees) along the South Skunk River near Oskaloosa than along the Iowa River near Marshalltown; a railroad bridge crosses the South Skunk River $0.4 \mathrm{mi}$ downstream of the U.S. Highway 63 bridge. Additional information is required to quantify the effects of factors which might be significantly contributing to aggradation at either the Marshalltown or Oskaloosa bridge sites.

\section{SUMMARY AND CONCLUSIONS}

Recent floods on the Iowa River at Marshalltown during 1990, 1991, and 1993 have resulted in the three highest stages for the period of record since at least 1915. Recurrence intervals for these three flood discharges are estimated to be 9,6 , and 16 years, respectively. Concerns by the Iowa Department of Transportation that aggradation on the Iowa River might be affecting the flow capacity of bridge openings in the vicinity of Marshalltown initiated this study to develop a better understanding of aggradation on the Iowa River. Four aggradation-measurement methods were used to investigate flood-plain and channel aggradation and to quantify aggradation rates at selected bridge sites. Aggradation rates were quantified at ten bridges sites on the Iowa River upstream of Coralville Lake; bridges were located both upstream and downstream of Marshalltown. Two bridge sites in the central part of the Skunk River Basin were investigated for comparative purposes.

A dendrogeomorphic measurement method was used to estimate mean and median flood-plain aggradation rates at the 12 bridge sites. Trees sampled for the dendrogeomorphic analyses ranged in age from 9 to 98 years. A bridge-opening cross-section measurement method was used to estimate average aggradation rates at bridge openings at the 12 bridge sites. Measurement periods used in the bridge-opening cross-section analyses ranged in length from 3 to 51 years. A stage-discharge rating-curve measurement method was used to estimate average floodway and channel aggradation rates at six of the bridge sites. Measurement periods used in the stage-discharge rating-curve analyses ranged in length from 5 to 75 years. Sediment-pad measurements were used to estimate average flood-plain aggradation rates for 1993 and for the period 1993-94 at three bridge sites on the Iowa River in the vicinity of Marshalltown.
Results of the aggradation measurements indicate that aggradation is occurring in both the Iowa and Skunk River Basins. For the 12 bridge sites investigated in the Iowa and Skunk River Basins, mean estimates of flood-plain aggradation rates calculated using the dendrogeomorphic method ranged from 0.013 to $0.051 \mathrm{ft} / \mathrm{yr}$, and median estimates ranged from 0.010 to $0.046 \mathrm{ft} / \mathrm{yr}$. Estimates of average aggradation rates at bridge openings calculated using the cross-section method ranged from -0.977 to $0.500 \mathrm{ft} / \mathrm{yr}$ at the 12 bridge sites. In general, slightly higher aggradation rates were estimated for the Iowa River for the reach from State Highway 330 near Albion downstream to County Road V66 at Marengo. The stage-discharge rating-curve method used the 5-year flood discharge to estimate floodway aggradation rates and the average discharge to estimate channel-aggradation rates at six bridge sites in the Iowa and Skunk River Basins with streamflow-gaging stations. Estimates calculated using the stage-discharge rating-curve method ranged from 0.028 to $0.298 \mathrm{ft} / \mathrm{yr}$ for floodway aggradation, and from -0.031 to $0.108 \mathrm{ft} / \mathrm{yr}$ for channel aggradation.

The highest aggradation rates calculated for the Iowa River using the dendrogeomorphic and ratingcurve methods were for the State Highway 14 crossing at Marshalltown, where these highest rates were 0.045 and $0.124 \mathrm{ft} / \mathrm{yr}$, respectively. The highest aggradation rates calculated for the Skunk River Basin were for the U.S. Highway 63 bridge crossing the South Skunk River near Oskaloosa, where these highest rates were 0.051 and $0.298 \mathrm{ft} / \mathrm{yr}$, respectively. The similar aggradation rates calculated for both the Marshalltown and Oskaloosa bridge sites using each measurement method, the dendrogeomorphic method and the ratingcurve method for the 5-year flood discharge, indicate that similar flood-plain and floodway aggradation processes might be occurring at the two sites.

Average flood-plain aggradation rates estimated from sediment-pad measurements at three of the bridge sites on the Iowa River in the vicinity of Marshalltown ranged from 0.037 to $1.100 \mathrm{ft} / \mathrm{yr}$ for 1993 , and ranged from 0.038 to $0.579 \mathrm{ft} / \mathrm{yr}$ for the period 1993-94. Sediments deposited on the pads as a result of the 1993 flood were variable and site specific, and depths of sediments deposited on the nine pads ranged from 0.004 to $2.95 \mathrm{ft}$.

A direct comparison cannot be made between aggradation rates calculated using each of the four measurement methods because of differences in time periods and aggradational processes that were mea- 
sured by each method. Each of the four aggradationmeasurement methods is useful for obtaining specific types of aggradation information and each method is considered applicable for specific types of regional or statewide investigations. The rating-curve method might provide the most useful information concerning flood-plain and channel aggradation, but rating-curve information only is available for a limited number of stream sites. The rating-curve method provides specific information on selected time periods of aggradation. The dendrogeomorphic and sediment-pad methods are applicable for most flood-plain sites. The bridge-opening cross-section method does not provide direct measurements of flood-plain or channel aggradation, but this method does provide useful information concerning possible changes in the flow capacity of bridge openings. Aggradation rates estimated using the bridge-opening cross-section method were more variable than the rates estimated using the dendrogeomorphic and rating-curve methods. Because cross sections were surveyed for bridge openings following the 1993 flood, cross-sectional areas at some of the bridge openings might have been affected by scour or deposition as a result of that flood. Aggradation rates calculated using the dendrogeomorphic method also may have been affected by the 1993 flood, as sedimentdeposition depths were measured following the flood. Aggradation rates calculated using the rating-curve method were not affected by the 1993 flood, as all of the rating curves used in the analyses were in effect before the flood.

Several interrelated factors might be contributing to the relatively high rate of aggradation of the Iowa River at Marshalltown. Erosion potential in the Iowa River Basin and sediment yields to the Iowa River increase between Alden and Eldora mainly as a result of the steeper topography that occurs in the basin as the Iowa River crosses from the Des Moines Lobe landform region to the Southern Iowa Drift Plain landform region. Although erosion potential in the Iowa River Basin and sediment yields to the Iowa River downstream of Marshalltown might be as great, or greater, than erosion potential and sediment yields to the Iowa River upstream of Marshalltown, aggradation rates apparently are greater for the Iowa River at Marshalltown than downstream of Marshalltown. Erosion is a problem in the Marshall County area and it might be intensified by the occurrence of thick deposits of loess soils. High sediment yields to the Iowa River might occur from channel erosion along the
Iowa River and from erosion from watersheds draining to the Iowa River in the Marshall County area. Channelization of the Iowa River upstream of Marshalltown reduced the length of the river and increased the gradient, and higher flow velocities probably occur through this channelized reach of the river. The sediment-transport capacity through the channelized reach of the river might deliver a high sediment load downstream to Marshalltown. At Marshalltown, where the Iowa River changes abruptly from a straightened reach to a meandering reach, flow velocities decrease as the channel gradient decreases, reducing the sedimenttransport capacity of the river and causing sediment to deposit.

Information on recent aggradation rates indicates that the Iowa River at Marshalltown might be aggrading at a rate greater than that calculated for longer measurement periods. A similar trend appears to be occurring for specific aggradational processes at three of the four other bridge sites where information on recent aggradation rates was available. Streamflow in the Iowa River at Marshalltown appears to have increased over the period of record (since about 1915). A trend of increasing streamflow for the Iowa River at Marshalltown combined with an aggrading channel might be causing more frequent overbank flows and increased flood-plain aggradation.

\section{REFERENCES CITED}

Blanchard, Frank, 1955, Straightening of Iowa River, in Schultz, Gerald, ed., History of Marshall County, Iowa: Marshalltown, Iowa, Marshall Printing Company, $244 \mathrm{p}$.

Bloom, A.L., 1978, Geomorphology, a systematic analysis of late Cenozoic landforms: Englewood Cliffs, N.J., Prentice-Hall, $510 \mathrm{p}$.

Campbell, K.L., and Johnson, H.P., 1970, Effects of stream straightening on flood runoff characteristics: Ames, Iowa, Iowa State University, Iowa State Water Resources Research Institute Project no. B-005-IA, $132 \mathrm{p}$.

Eash, D.A., 1993, Estimating design-flood discharges for streams in Iowa using drainage-basin and channelgeometry characteristics: U.S. Geological Survey Water-Resources Investigations Report 93-4062, 96 p.

Erbe, N.A., and Flores, D.T., 1957, Iowa drainage laws (annotated): Iowa Highway Research Board Bulletin no. $6,870 \mathrm{p}$.

Fischer, E.E., 1995, Potential-scour assessments and estimates of maximum scour at selected bridges in Iowa: 
U.S. Geological Survey Water-Resources Investigations Report 95-4051, 75 p.

Heinitz, A.J., 1973, Floods in the Iowa River Basin upstream from Coralville Lake, Iowa: U.S. Geological Survey Open-File Report, 75 p.

Heinitz, A.J., and Wiitala, S.W., 1978, Floods in the Skunk River Basin, Iowa: U.S. Geological Survey Open-File Report 79-272, 80 p.

Hupp, C.R., and Bazemore, D.E., 1991, Dendrogeomorphic analysis of wetland sedimentation: Fifth Federal Interagency Sedimentation Conference Proceedings, v. 1, sec. 4 , p. $40-47$.

Hupp, C.R., and Morris E.E., 1990, A dendrogeomorphic approach to measurement of sedimentation in a forested wetland, Black Swamp, Arkansas: Wetlands, v. 10, p. 107-124.

Hupp, C.R., and Simon, Andrew, 1991, Bank accretion and the development of vegetated depositional surfaces along modified alluvial channels: Amsterdam, Elsevier Science Publishers B.V., Geomorphology, v. 4, p.111124.

Interagency Floodplain Managenent Review Committee, 1994, Sharing the challenge, Floodplain management into the 21st century: Washington, Report of the Interagency Floodplain Management Review Committee to the Administration Floodplain Management Task Force, June 1994, 189 p.

Iowa Conservation Commission, 1979, Iowa's low-head dams-Their past, present, and future roles: Des Moines, Iowa, Iowa State Water Resources Research Institute Special Report no. 96, 312 p.

Iowa Natural Resources Council, 1955a, An inventory of water resources and water problems, Iowa-Cedar River Basin, Iowa: Des Moines, Iowa, Iowa Natural Resources Council Bulletin no. 3, 94 p. 1955b, An inventory of water resources and water problems, Nishnabotna River Basin, Iowa: Des Moines, Iowa, Iowa Natural Resources Council Bulletin no. 2, 61 p.

1957, An inventory of water resources and water problems, Skunk River Basin, Iowa: Des Moines, Iowa, Iowa Natural Resources Council Bulletin no. 5, 66 p.

Johnston, C.A., Bubenzer, G.D., Lee, G.B., Madison, F.W., and McHenry, J.R., 1984, Nutrient trapping by sediment deposition in a seasonally flooded lakeside wetland: Journal of Environmental Quality, v. 13, p. 283290.

Kennedy, E.J., 1984, Discharge ratings at gaging stations: U.S. Geological Survey Techniques of WaterResources Investigations, book 3, chap. A10, 59 p.

Lane, E.W., 1938, Report on investigation of sediment carried by rivers of St. Paul, U.S. Engineer District, 1937 and 1938: Iowa City, Iowa, The University of Iowa, Iowa Institute of Hydraulic Research, $42 \mathrm{p}$.
1955, The importance of fluvial morphology in hydraulic engineering: American Society of Civil Engineers Proceedings, v. 81, no. 795, 17 p.

Lara, O.G., 1987, Method for estimating the magnitude and frequency of floods at ungaged sites on unregulated rural streams in Iowa: U.S. Geological Survey WaterResources Investigations Report 87-4132, 34 p.

Mackin, J.H., 1948, Concept of the graded river: Bulletin of the Geological Society of America, v. 59, p. 463-512.

Marshalltown Times-Republican, February 15, 1991, newspaper article.

Matthai, H.F. 1967, Measurement of peak discharge at width contractions by indirect methods: U.S. Geological Survey Techniques of Water-Resources Investigations, book 3, chap. A4, 44 p.

May, J.E., Sneck-Fahrer, D., Gorman, J.G., Goodrich, R.D., Nations, B.K., and Miller, V.E., 1995, Water resources data, lowa, water year 1994: U.S. Geological Survey Water-Data Report IA-94-1, 390 p.

Nakato, Tatsuaki, 1981, A review of sediment-transport studies of the GREAT-I and GREAT-II reaches of the upper Mississippi River: Iowa City, Iowa, The University of Iowa, Iowa Institute of Hydraulic Research Limited Distribution Report no. 89, 52 p.

Odgaard, A.J. 1984, Bank erosion contribution to stream sediment load: Iowa City, Iowa, The University of Iowa, Iowa Institute of Hydraulic Research Report no. $280,92 \mathrm{p}$.

Oschwald, W.R., Riecken, F.F., Dideriksen, R.I., Scholtes, W.H., and Schaller, F.W., 1965, Principal soils of Iowa: Ames, Iowa, Iowa State University, Department of Agronomy, Special Report no. 42, 77 p.

Owenby, J.R., Garvin, Cindy, Nicodemus, Larry, and Heim, Jr., R.R., 1992, Divisional temperature $\left({ }^{\circ} \mathrm{F}\right)$ and precipitation (inches) normals and standard deviations 1931-1990: Asheville, N.C., National Climatic Data Center, National Oceanic and Atmospheric Administration, Climatography of the United States no. 85, 306 p.

Phipps, R.L., 1985, Collecting, preparing, crossdating, and measuring tree increment cores: U.S. Geological Survey Water-Resources Investigations Report 85-4148, $48 \mathrm{p}$.

Phipps, R.L., Johnson, G.P., and Terrio, P.J., 1995, Dendrogeomorphic estimate of changes in sedimentation rate along the Kankakee River near Momence, Illinois: U.S. Geological Survey Water-Resources Investigations Report 94-4190, 30 p.

Prior, J.C., 1991, Landforms of Iowa: Iowa City, Iowa, Iowa Department of Natural Resources, University of Iowa Press, $153 \mathrm{p}$.

Salisbury, N.E., Knox, J.C., and Stephenson, R.A., 1968, The valleys of Iowa-1, Valley width and stream discharge relationships in the major streams: Iowa City, Iowa, The University of Iowa, Department of Geogra- 
phy, Iowa State Water Resources Research Institute, Iowa Studies in Geography, no. 5, 107 p.

Simon, Andrew, 1994, Gradation processes and channel evolution in modified west Tennessee streams, Process, response, and form: U.S. Geological Survey Professional Paper 1470, $84 \mathrm{p}$.

Simon, Andrew, and Hupp C.R., 1992, Geomorphic and vegetative recovery processes along modified stream channels of west Tennessee: U.S. Geological Survey Open-File Report 91-502, 142 p.

Trimble, S.W., and Lund, S.W., 1982, Soil conservation and the reduction of erosion and sedimentation in the Coon Creek Basin, Wisconsin: U.S. Geological Survey Professional Paper 1234, $34 \mathrm{p}$.

Turnipseed, D.P., and Wilson, Jr., K.V., 1992, Channel and bank stability of Standing Pine Creek at State Highway 488 near Freeny, Leake County, Mississippi: U.S. Geological Survey Open-File Report 92-112, 18 p.

Upper Mississippi River Basin Commission, 1979, Water resources subregion plan, Subregion 0708, Iowa-

Skunk-Wapsipinicon River Basin: Minneapolis, Minn., (Working Draft), October 1979, 205 p.

Upper Mississippi River Comprehensive Basin Study Coordinating Committee, 1970, Upper Mississippi River comprehensive basin study: v. III, appendices $\mathrm{C}-\mathrm{G}$, $518 \mathrm{p}$.

U.S. Army Chief of Engineers, 1930, Iowa River, Iowa and Minnesota: Committee on Rivers and Harbors, 71st Congress, 2nd Session, December 16, 1929: Washington, U.S. Government Printing Office, House Document no. 134, $166 \mathrm{p}$.

U.S. Army Corps of Engineers, 1981, Characterization of the suspended-sediment regime and bed-material gradation of the Mississippi River Basin: Vicksburg, Miss., Environmental Laboratory, U.S. Army Engineer Waterways Experiment Station, Potamology Program (P-1), Report 1, v. 1, 493 p.
1990, Impact of changes in suspended-sediment loads of the regime of alluvial rivers: Vicksburg, Miss., Environmental Laboratory, U.S. Army Engineer Waterways Experiment Station, Potamology Program (P-1), Report 6, 130 p.

1993, Water resources development in Iowa 1993: U.S. Government Printing Office, North Central Division, Rock Island District, 98 p.

U.S. Congress, 1985, Food Security Act of 1985-The committee of conference submitted the following conference report to accompany H.R. 2100, 99th Congress, 1st Session, December 17, 1985: Washington, D.C., U.S. Government Printing Office, House Report 99-447, $616 \mathrm{p}$.

U.S. Geological Survey, 1904-1995, Water resources data, Iowa, water years 1903-94 (published annually): U.S. Geological Survey Water-Data Reports. 1990-95, Water resources data, Iowa, water years 1989-94 (published annually): U.S. Geological Survey Water-Data Reports.

Vanoni, V.A., 1975, Sedimentation engineering: New York, American Society of Civil Engineers, 745 p.

Wilson, Jr., K.V., and Turnipseed, D.P., 1994, Geomorphic response to channel modifications of Skuna River at the State Highway 9 crossing at Bruce, Calhoun County, Mississippi: U.S. Geological Survey WaterResources Investigations Report 94-4000, 43 p.

Winkley, B.R., 1981, A geomorphic model of the relationship of variables in a drainage basin: presented at the International Symposium on Rainfall Runoff Modeling, Mississippi State University, Mississippi State, Miss.

Wolfe, W.J., and Diehl, T.H., 1993, Recent sedimentation and surface-water flow patterns on the flood plain of the North Fork Forked Deer River, Dyer County, Tennessee: U.S. Geological Survey Water-Resources Investigations Report 92-4082, 22 p. 